\title{
DIETAS PALATÁVEIS DE CUSTO MÍNIMO PARA A POPULAÇÃO DA CIDAdE DE SÃO PAULO
}

ANA MARIA HOLLAND OMETTO

Orientador: JOAQUIM JOSÉ DE CAMARGO ENGLER

Dissertação apresentada à Escola Superior de Agricultura "Luiz de Queiroz" da Universidade de São Paulo, para obtenção do título de Mestre em Economia Agrária.

PIR A C I C A B A

Estado de São Paulo - Brasil

Junho, 1978 
i i .

a meus pais

a meu marido

a meus filhos 


\section{AGRADECIMENTOS}

Ao Prof. Dr. Joaquim José de Camargo Engler, orientador desta dissertação, pelo estímulo constante e pela cuidadosa revisão crítica do texto original.

Aos professores Dr. Fernando Curl Peres e. Dr. Geraldo Sant'Ana de Camargo Barros pelas críticas e sugestões apresentadas na re visão dos originais.

Ao Sr. Wilson Roberto Negri pela colaboração prestada nos serviços de programação e computação.

Ao Sr. Dalton Pires Baptista pelo auxilio prestado na fase de codificação dos dados.

A Sra. El isa da Silva Peron, Srta. Ana Assunção Beltrame, Sra. Margareth P. Wagner e Sr. Läzaro Martins pela colaboração nos trabalhos de publicação desta pẹsquisa.

Ao Instituto de Pesquisas Econômicas da Universidade de São Paulo que forneceu os dados básicos para o presente trabalho.

A Fundação Ford e ao Departamento de Economia e Sociologia Rural pelo auxillio financeiro concedido para a realização deste trabaltho.

A todos que, direta ou indiretamente, constribuiram para a realização desta pesquisa. 
TNDICE

Pägina

LISTA TABELAS $\ldots \ldots \ldots \ldots \ldots \ldots \ldots \ldots \ldots \ldots \ldots \ldots \ldots \ldots \ldots \ldots \ldots \ldots \ldots$

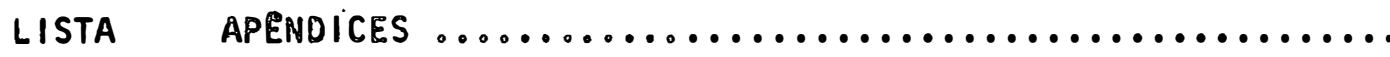

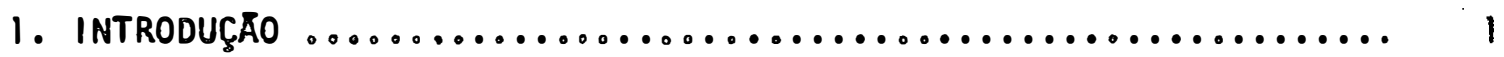

1.1. 0 problema e sua importåncia ......................

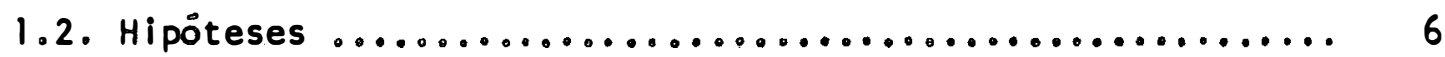

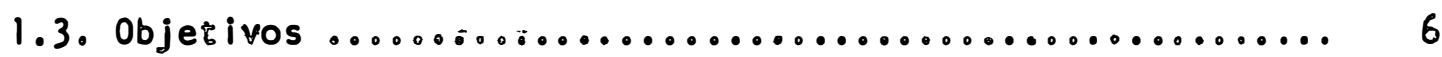

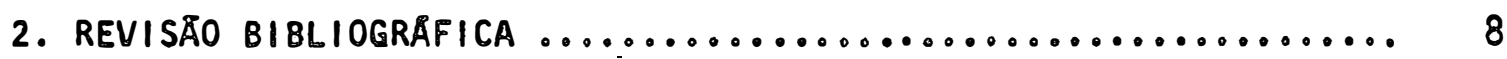

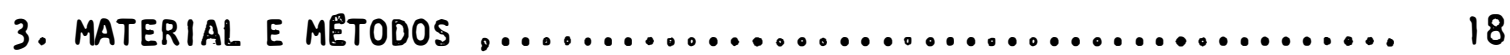

3.1. Caractepisticas do levantamento e apresentação dos dados da Pesquisa de Orçamentos Familiares na Cidade de Sảo Paulo - (POF) ............................ 19

3.2. Adequação nưricional da àl imentação da população paulistana .................................. 23

3.2.1. Informação bãsica ....................... 23

3.2.2. Adequação nutricional da alimentação .......... 35

3.3. Câlculo das dietas de custo minimo ................ 36

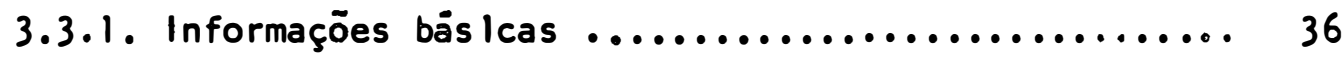

3.3.2. Instrumental analitico ................... 37

4. RESULTADOS E DISCUSSÃO ........................... 46

4.1. Adequação nutricional da alimentação adquirida .... .... 46

4.2. Dietas de custo minimo ........................ 57

4.2.1. Indice de eficiência dos gastos em alimentação .... 57

4.2.2. Dietas obtidas com o modelo simples ............ 63 
4.2.3. Dietas obtidas com o modelo palatävel .......... 70

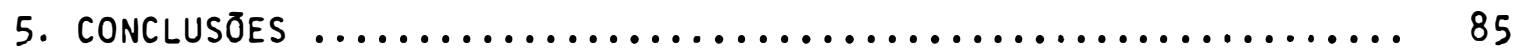

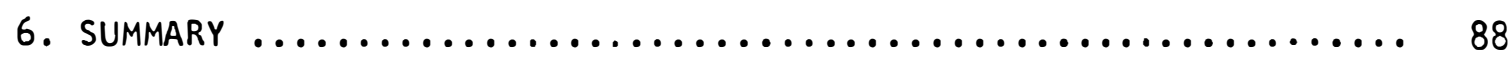

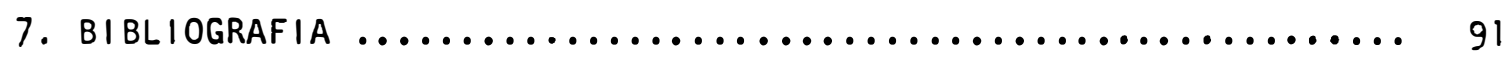




\section{LISTA DE TABELAS}

Tabela n?

Página

1 Taxa de Mortalidade Infantil no Municipio de Såo Paulo ... 3

2 Estratificação da População Amostrada segundo a Renda Familiar .................................. 21

3 Habitantes e Pessoas que Trabal ham por familia nas Diversas Classes de Renda ......................... 22

4 Ingestōes Diårias de Nutrientes Recomendadas pela FAO/WHO_................................. 28

5 Porcentagem de Perdas dos Nutrientes Ocorridas Durante

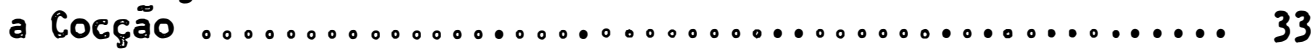

6 Necessidades Nutricionais Mensais de Familias Me̊dias ..... 50

7 Disponibilidade Mensal de Nutrientes por Familla Mé-

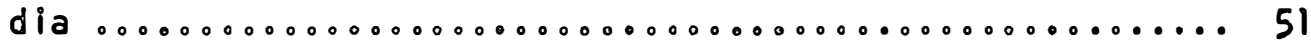

8 Intervalo de Adequação Nutricional (em $\%) \ldots \ldots \ldots \ldots \ldots$

9 Porcentagem de Caloria Al imentar de Origem Animal e Ve

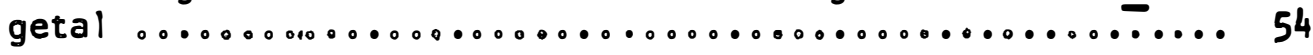

10 Porcentagem de Proteina Alimentar de Origem Animal e Vegetal ...................................... 56

11 Alimentos e Respectivas Quantidades nas Dietas de Custo Minimo Elaboradas com Base nas Dietas Adquiridas pe las Familias da Amostra ........................ 59

12 Teor de Nutrientes das Dietas de Custo Minimo Elaboradas com Base nas Dietas Adquiridas pelas Familias da

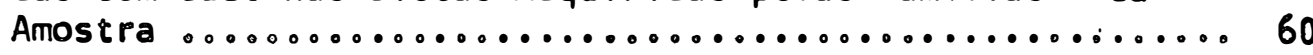

13 Indices de Eficiência da Alimentação Adquirida ......... 62

$14 \quad$ Alimentos e Respectivas Quantidades nas Dietas de Custo Minimo Elaboradas Através do Modelo Simples ............ 64

15 Teor de Nutrientes das Dietas de Custo Minimo Elabora-

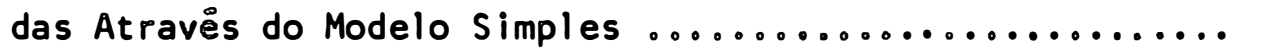


16 Custo da Al imentação Adquipida pelas Familias da Amos tra e da Dieta de Custo Minimo Elaborada Arravés do Mo

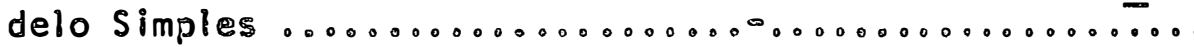

17 Percentagens das Rendas Necessâpias para a Aquisição das Dieras de Custo Minimo El aboradas Arravés do Modelo Simples

18 Alimentos, Respectivas Qume idades e Atividade Dual das Dietas Obtidas Arraves do Modelo Palativel papa a Familia Média da Classe de Renda 1 o..............

19 Alimentos, Respecrivas Quantidades e Arividade Dual das Dietas Obridas Através do Modelo Palaravel papa a Familia Média da Classe de Renda $2 \ldots \ldots \ldots \ldots \ldots \ldots \ldots . .$.

20 Al imentos, Respectrivas Quantidades e Arividade Dual das Dieras Obridas Arravés do Modelo Palarảvel para

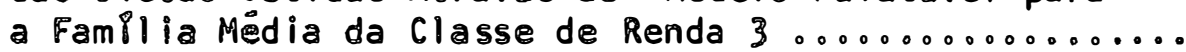

21 Alimentos Respectivas Quantidades e Arividade Dual das Dieras Obridas Arpavës do Modelo Palatável para a Familia Média da Classe de Renda 4 ................

22 Alimentos, Respectivas Quarridades e Arividade Dual das Dietas Obtidas Arpavés do Modelo Palatånel para a Famillia Médía da Classe de Renda 5 .............. 76

23 Alimentos, Respectivas Quancidades e Arividade Dual das Dieras Obridas Arravés do Modelo Palaråvel para a Familia Media da Classe de Renda 6 ...............

24 Teor de Nutrientes das Dietas de Custo Minimo Elabora das Acravés do Modelo Palatãvel

25 Gusto da Al imen baçæ̋ Adquirida e da Diera de Custo Mi nimo Elaborada Atrayés do Modelo Pal tåvel ............

26 Percencagens das Rendas Necessärias para a Aquisição das Dieras de Custo Minimo Elaboradas Atraves do Mode 10 Pala 


\section{LISTA DE APENDICES}

APENDICE ।

Pågina

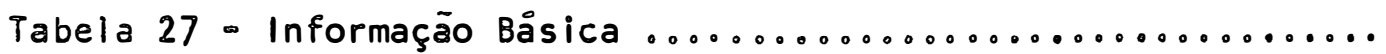

\section{APENDICE 2}

Tabela 28 - Composição dos Alimentos Descontada a Porção não Comestivel e as Perdas por Cocção ................

\section{APENDICE 3}

Tabela 29 - Anålise "Pösoỏtima" das Dietas Elaboradas Atravës do Modelo Simples para a Classe de Renda I, Preços Unitårios, Måximos e Mínimos Pepmitidos e Res

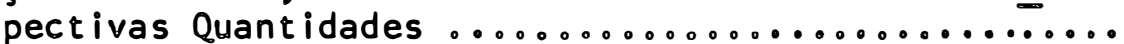

Tabela 30 - Anälise "Po̊s-o̊tima" das Dietas Elaboradas Atravës do Modelo Simples para a Classe de Renda 2, Preços Unitários, Máximos e Mínimos Permitidos e Res pectivas Quantidades

Tabela 31 o Anälise "Pösmo̊tima" das Dietas Elaboradas Atravēs do Modelo Simples para a Classe de Renda 3, Preços Unitårios, Måximos e Mínimos Permitidos e Res pectivas Quantidades

Tabela 32 - Anålise "Po̊s-ōtima" das Dietas Elaboradas Através do Modelo Simples para a Classe de Renda 4, Preços Unitårios, Måximos e Minimos Permitidos e Res

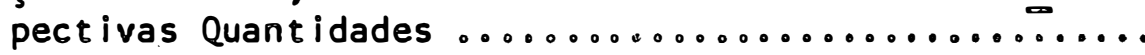

Tabela 33 - Anålise "Po̊s ötima" das Dietas Elaboradas Atravës do Modelo Simples para a Classe de Renda 5, Preços Unitårios. Måximos e Minimos Permitidos e Res

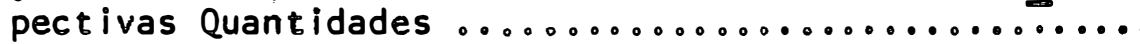

Tabela 34 - Anålise "Pösøōtima" das Dietas Elaboradas Através do Modelo Simples para a Classe de Renda 6, Preços Unitårios, Måximos e Mỉnimos Permitidos e Res pectivas Quantidades ....................... 
Tabela 35 - Anālise "Pös-ótima" da Dieta Mensal Resultante da Apl icação do Modelo Palatável à Familia Média da Classe de Renda 1 ...............................

Tabela 36 - Anālise "Pös-ötima" da Dieta Mensal Resultante da Apl icação do Modelo Palatável, à Famillia Média da Classe de Renda 2 ............................

Tabela 37 - Anälise "Pós-ótima" da Dieta Mensal Resultante da Apl icação do Modelo Palatävel Apl icado à Famillia Média da Classe de Renda 3 .......................

Tabela 38 - Anālise "Pös-ötima" da Dieta Mensal Resultante da Aplícação do Modelo Palatāvel à Famillia Média da Classe de Renda 4 .............................

Tabela 39 - Anālise "Pös-ötima" da Dieta Mensal Resultante da Apl icação do Modelo Palatável à Famill la Média da

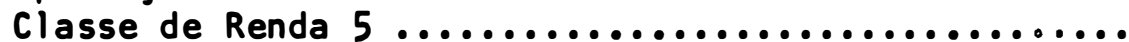

Tabela 40 - Anälise "Pös-ötima" da Dieta Mensal Resultante da Aplicação do Modelo Palatãvel à Famillia Média da Classe de Renda 6 
RESUMO

0 presente trabalho teve como objetivos principais: analisar a adequação nutricional da alimentação de uma amostra de familias da população paulistana e determinar dietas de custo mínimo adequadas no aspecto nutricional, palatäveis, e que observassem certos hảbitos alimen tares da referida amostra.

Para isso utilizaramose os dados obtidos pela Pesquisa de Orçamentos Familiares na Cidade de São Paulo realizada no período compreendido entre agosto de 1971 a julho de 1972, que levantou informações sobre a estrutura do consumo de 2380 familias.

Essas informações foram coletadas por familia, mas apresentadas agrupadas em quatorze classes de renda familiar.

A adequação nutricional da al imentação adquirida pelas fá milias mẻdias representativas de cada classe de renda foi calculada atra vẻs da comparação das necessidades nutricionais dessas famillias com 
as quantidades de nutrientes fornecidas pela al imentação comprada.

Para o estabelecimento das necessidades nutricionais optou-se pelas recomendações da FAO adaptadas para a temperatura anual mé dia da região.

Os resultados mostraram a relação direta existente entre renda e adequação alimentar, sendo que nas primeiras seis classes as deficiências nutricionais foram grandes, principalmente em ferro, retinol, tiamina e riboflavina.

A seguir, utilizando-se da programação linear, calcularam-se dietas de custo mínimo que preenchessem as necessidades de nutrientes das familias mëdias dessas seis classes de renda.

As soluções ötimas obtidas, alèm de satisfazerem as recomendações nutricionais'da população analisada, ainda apresentaram em todos os estratos de renda custos nítidamente inferiores aos da alimentação usual. Todavia, apresentaram limitações que impediam a sua aceitabi lidade, tais como: pouca variedade aliada ao aparecimento de quantidades el evadas de um mesmo alimento e não inclusão de condimentos.

Elaborou-se um segundo modelo, que alèm de considerar as necessidades nutricionais da população, ainda estabeleceu um conjunto am plo de restriçöes com o objetivo de conseguir cardåpios estruturados de acordo com hảbitos alimentares da população amostrada, palatáveis, com razoåvel variedade e adequadamente condimentados. 
As dietas obtidas atravēs desse segundo modelo, apesar de consideravelmente mais caras que as resultantes do primeiro, ainda tiveram custo inferior ao da alimentação usual, exceto para a classe de menor poder aquisitivo.

Embora não fosse possivel testar a sua aceitabilidade, acredita-se que esta seja razoāvel, pois as restriçōes estipuladas visavam uma certa conformidade com a al imentação usual.

o programa de computação utilizado forneceu, além das dietas de custo mínimo, uma anälise de sensibilidade que indica as modificaçōes que pode ter a solução ötima, em decorrência de alteraçōes nos preços dos alimentos. 
1. INTRODUÇÃO

\subsection{O problema e sua importância,}

Embora o desenvolvimento econômico e social seja basicamen te a meta para a qual todas as nações dirigem seus esforços, ainda hoje os economistas não chegaram a um acordo sobre o que ele significa. Para muitos, os agregados monetários deixaram de ser indicadores únicos, passando outras medidas, tais como o consumo "per capita" de certos bens, a caracterizar o nível de desenvolvimento de um país.

A alimentação mais do que um indicador, vem sendo paulatinamente considerada como um agente propiciador do desenvolvimento. As polifticas de melhoria da situação nutricional perderam seu carärer puramente humanistico, passando a ser encaradas atualmente como uma forma de que brar o círculo vicioso má nutrição - baixa produtividade - pobreza.

A melhoria da situação nutricional pode ser visualizada co mo um agente de desenvolvimento econômico por resultar na elevação da pro dutividade do indivíduo, extensão dos anos de vida economicamente ativa (reduzindo assim a razão de dependência), poupança em gastos médicos, 
além de que os retornos em outros investimentos intimamente relacionados com a nutrição, principalmente educação, poderão ser ampliados. '/

Embora seja desconhecida a incidência precisa de mä nutrição no mundo, GOLDSMITH (1969) mostra estimativas segundo as quais nos países menos desenvolvidos cerca de $20 \%$ da população estä subnutrida e ao redor de $60 \%$ recebe dietas inadequadas do ponto de vista nutricional.

Durante 0 2: Congresso Nutricional do Hemisfério Ocidental em 1968 foi salientada a alta correlação entre mä nutrição e mortalidade infantil na Amèrica Latina 2 / e mencionado que os progressos alcançados na reduçäo da mortalidade em anos posteriores de vida parecem não ter afe tado a taxa de mortalidade na infância.

BERG (1973) enfatiza que no Brasil, crianças abaixo de 5 anos de idade constituem $20 \%$ da população, mas contribuem para $80 \%$ das mortes. E interessante comparar essa situação com a encontrada nos Estados Unidos, onde crianças atē essa idade constituem $8,8 \%$ da população e $4,8 \%$ das mortes.

I/ BERG (1973) cita que em 1968, em 37 paises em desenvolvimento, aproximadamente $1 / 2$ milhão de pacientes foram registrados por mä nutrição, o que representa um custo de 340 milhôes de dólares anuais para esses paises. Além disso os paises de baixa renda gastam aproximadamente $4 \%$ de seu produto nacional em educação, sendo que a eficiência do sistema educacional pode ser reduzida de até $50 \%$ pela evasão e repetência, para as quais a má nutrição contribui pesadamente.

2/ A esse respeițo BERG (1973) identifica as deficiências nutricionais co mo causa primária ou associada em 57\% de todas as mortes de 1 a 4 anos de idade na América Latina. 
Especificamente para a cidade de São Paulo, a taxa de mortalidade infantil tem recrudescido nos ültimos anos (Tabela 1) o que pode estar associado a um agravamento da situação alimentar na região.

Tabela 1. Taxa de Mortalidade Infantil no Municipio de São Paulo.

Anos

Taxa de Mortalidade Infantil

(Mortes antes do 1: ano/1000 hab)

1960

62,9

1963

62,9

1964

67,7

1965

69,4

1966

73,8

1967

74,4

1968

76,6

1969

83,8

Fonte: IBGE - Anuärios Estatísticos de 1968, 1969 e 1970.

A associação entre as causas da mortalidade infantil no mu nicipio de Säo Paulo em 1968, e as deficiências nutricionais foram avalia das pela Organização Panamericana da Saüde que chegou a conclusão que essa associação prevalecia em $47 \%$ dos casos.

LAURENTI (1973) cita pesquisa efetuada pela Investigação Interamericana de Mortalidade na Infância, no Município de São Paulo no período de $1968 / 70$, segundo a qual a desnutrição esteve presente como cau sa bảsica ou associada em $28 \%$ dos öbitos de menores de um ano, sendo que 
as doenças infécciosas, que tambẻm guardam relação com a desnutrição, representaram $65,4 \%$ da mortalidade infantil na região.

CAMPINO E ALVES (1974) mencionam estudos realizados pelos örgãos IMPEP/IPE mostrando que na cidade de São Paulo, das crianças pesquisadas, com idade variando entre 6 meses e 5 anos, 22,4\% apresentaram desnutrição proteica e calörica, em sua maioria de 1 : grau, e $30 \%$ anemia ferropriva.

Apesar das consequências da má nutrição e subnutrição serem mais graves na infância, logicamente não atingem apenas as crianças na regiāo. Desconhece-se informaçōes clínicas a respei to da carência nu tricional em adolescentes e adultos, mas entre os estudos que analisaram a alimentação da população paulistana em termos de adequação nucricional encontra-se o de SOBOLL (1973) no qual concluiu que a população trabalhadora do município de São Paulo apresentava consumo insuficiente em proteínas, cälcio e vảrias vitaminas.

Basicamente as deficiências nutricionais ocorrem em virtude da ingestāo de nutpientes em níveis aquẻm dos requerimentos mínimos ou devido à dificuldade de absorção dos nutrientes ingeridos. Os pesquisadores da ciência biomédica tem se preocupado mais frequentemente com esse segundo fator e os da ciências sociais com o primeiro.

Entre as medidas sugeridas pelos estudiosos para aumentar a ingestāo nutricional encontramos:

- o aumento de produção e produtividade agrícola com consequente redução no custo dos gêneros alimentícios; 
- medidas visando o enriquecimento nutricional dos alimentos ou a mudança de häbitos alimentares de forma a aumentar a ingestão de al imentos considerados de boa qualidade;

- a elevação da renda da população de baixo poder aquisiti vo, atravēs de medidas de redistribuição de renda;

- a racionalização da dieta.

0 presente trabalho relaciona-se com esta ültima medida e. tem como objetivo geral a determinação de dietas nutricionalmente adequadas, palatāvels e de custo mínimo. Especificamente para a população paulistana admite-se que as classes de baixo poder aquisitivo, apenas por uma realocação dos recursos destinados à alimentação possam conseguir die tas adequadas.

Este estudo pode ser considerado bäsico na organização e execução de programas de educação al imentar e de produção de alimentos, visto que os informes sobre a composição de uma alimentação de custo mínimo, adequada no aspecto quantitativo e qualitativo, podem servir como subsídios para a orientação racional que se deve conferir a tais programas.

3/ Entre elas podemos citar as medidas governamentais determinando o enriquecimento da farinha de trigo, o sal iodado, certas descobertas genéticas que ampliaram a qualidade nutricional dos alimentos, tais como - milho opaco 2 e campanhas visando estimular o consumo de soja, pei$x e$, etc. 


\subsection{Hipöteses}

a) Nas classes de renda mais baixa, a alimentação dos indivíduos é inadequada do ponto de vista nutricional;

b) As dietas dos indivíduos nas referidas classes, apesar de nutricionalmente inadequadas apresentam custo superior ao de uma dieta adequada de custo mínimo;

c) Ésível obter dietas com valor nutricional equivalen te às atuais por um custo menor usando-se a programação linear para a definição das referidas dietas.

1.3. Objetivos.

Os objetivos específicos desta pesquisa são:

a) Analisár os índices de adequação nutricional da alimentação adquirida pela população paulistana estratificada por classe de ren da ;

b) Obter dietas adequadas nutricionalmente e de custo minimo considerando os alimentos disponíveis na região em estudo;

c) Em função de restriçōes formuladas sobre preferências dos consumidores e palatabilidade das dietas encontrar outras dietas adequadas nutricionalmente e de custo mínimo;

d) Verificar se hä possibilidade das classes de baixa renda, apenas através de uma realocação dos recursos destinados à alimentação, conseguirem dietas palatäveis e adequadas no aspecto nutricional; 
e) Confrontar a situação existente com as programadas a fim de verificar as possibilidades de melhoria na alimentação dos habitan tes da regiāo em apreço;

f) Obter medidas de eficiência dos dispêndios em alimentação. 
2. REVISÃO BIBLIOGRĀFICA

AMARAL (1963) estudando o custo de dietas adequadas para a população paulistana durante o período de 1941-1953, concluiu que a população não poderia obter a ração essencial mínimal/ se quisesse manter um "orçamento doméstico satisfatório". Citou que em 1941, ano no qual a relação custo da ração essencial mínima/renda média da população foi a me nor do período, as famílias precisariam dispender $75 \%$ de sua renda na com pra de al imentos para se alimentarem adequadamente.

SIQUEIRA (1968) em trabalho apresentado no II Simpósio Bra sileiro de Alimentação e Nutrição, salientou que para um trabalhador que recebe salärio mínimo, conseguir a ração essencial mínima para uma família de 5 pessoas, ele deveria destinar $147,8 \%$ de sua renda à alimentação; um funcionärio püblico estadual nível 7 deveria dedicar 137,20\% e um professor universitärio nível 19 em tempo integral deveria dedicar $23 \%$.

1 Esta ração essencial mínima foi estabelecida pelo Decreto Lei n: 399 de $30 / 04 / 1938$. 
- Departamento Intersindical de Estatística e Estudos Söcio Econômicos (DIEESE 1972) calculou o custo da ração essencial minima em São Paulo em dezembro de 1971, chegando ao resultado de Cr\$106,79. Desta forma, para atender al ém das despesas alimentares, os gastos com a habitaçāo, vestuärio, higiene e transporte, o salärio mínimo necessärio determinado através dos cálculos do DIEESE deveria ser Cr\$ 759,70 no cita do ano.

Os estudos mencionados se preocuparam apenas com o custo de dietas adequadas do ponto de vista nutricional sem apresentar suges tỏes para uma redução no seu custo.

Outros pesquisadores tem procurado, seguindo diferentes me todologias, obter dietas adequadas e de baixo custo. Assim, grandes esforços tem sido dedicados à procura de alimentos que forneçam maiores con tribuiçōes nutricionais a custos mais baixos.

TREMOLIERES, SEVILLE e JACQUOT (1962) considerando cada nu triente isoladamente, sugeriram a seguinte expressão para identificar as fontes de menores custos dos nutrientes: se $E_{j} \ddot{e}$ a porção comestivel em um $\mathrm{kg}$ do alimento $\mathbf{j}, N_{i j} \ddot{e}$ o montante do nutriente $i$ obtido em um $\mathrm{kg}$ de porção comestivel do alimento $j$, e $P_{j}$ é o preço de um $k g$ do alimento j como vendido, então

$$
T_{i j} \frac{E_{j} N_{i j}}{P_{j}}
$$

onde:

$$
\begin{aligned}
T_{i j}= & \text { quantidade do nutriente } i \text { consumido por cruzeiro gasto no ali- } \\
& \text { mento } j
\end{aligned}
$$




$$
\begin{aligned}
& i=1, \ldots, m \\
& j=1, \ldots, q
\end{aligned}
$$

De acordo com essa metodologia, o alimento com o maior $T_{i j}$ $\ddot{e}$ a fonte mais econônica do nutriente i.

A principal falha desse método $\dot{e}$ a de não considerar que a contribuição nutricional de um alimento deve incluir todos os nutrientes que o alimento fornece.

TERROINE (1962) preparou uma tabela, na qual as linhas são os alimentos e as colunas os nutrientes. Na intersecção da linha com a coluna ele escreveu os $T_{i j}$ de Tremoliēres e classificou os alimentos de acordo com o nümero de vezes que aparecia como a mais econômica ou a segunda mais econômica fonte de nutrientes.

Este método também estå sujeito a críticas, pois em virtude de considerar apenas a colaboração de um alimento quando é a fonte de menor custo, em primeiro ou segundo lugar, de um nutriente, elimina as de mais contribuições nutricionais do alimento.

CHRISTENSEN (1943), levou em consideração no eålculo da contribuição nutricional do alimento todos os nutrientes que ele fornece. Sendo $N_{i j}$, a quantidade do nutpiente $i$ obtida em 1 kg de porção comestivel do alimento $\mathfrak{d}$ e $R_{i}$ a recomendação do nutriente $i$, então:

$$
c_{j}=\frac{1}{m} \sum_{i=1}^{m} \frac{N_{i} j}{R_{i}}
$$


onde:

$$
\begin{aligned}
C_{j}= & \text { valor nutricional total de } 1 \mathrm{~kg} \text { de porção comestível do alimen- } \\
& \text { to } j . \\
j= & 1, \ldots, q \\
m= & n \text { ? de nutrientes considerados }
\end{aligned}
$$

Para se obter o valor nutricional total do alimento j como comprado, multiplica-se os $C_{j}$ por $E_{j}$, onde $E_{j}$ é a porção comestível do alimento j como vendido. Dividindo-se esse resultado pelo preço dos alimen tos respectivos, aquele que der o maior quociente será o alimento cujo cus to da contribuição nutricional serả menor.

Como o método considera todos os nutrientes com igual importância, pode levar a escolhas não econômicas dependendo do caso em questão.

$$
\text { DAVIS (1965), tentando eliminar esse problema, propôs uma }
$$
medida de contribuição mūltipla de um alimento usando a seguinte förmula:

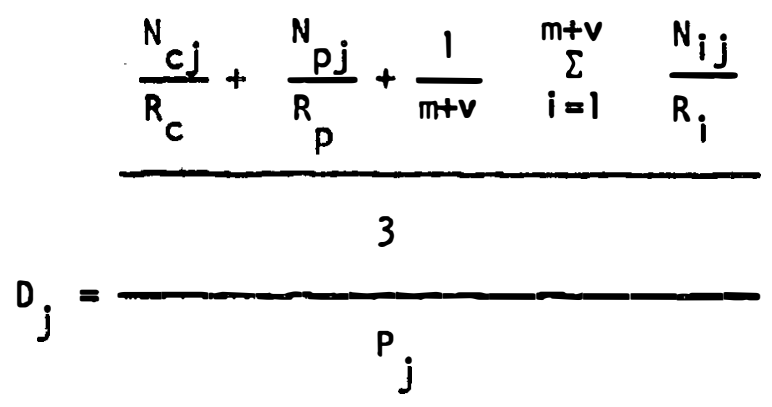

onde:

$$
\begin{aligned}
D_{\mathbf{j}}= & \text { fornece um índice económico dos nutrientes do alimento } \mathbf{j} \text { como } \\
& \text { comprado } \\
\mathbf{j}= & 1, \ldots, q \\
m= & n \text { ? de minerais no estudo } \\
V= & n \text { ? de vitaminas no estudo }
\end{aligned}
$$


$\mathrm{N}_{c j}=$ montante de calorias na porçåo comestivel de $100 \mathrm{~g}$ do alimento $j$ como comprado

$\mathrm{N}_{\mathrm{pj}}=$ montante de proteinas na porção comestivel de $100 \mathrm{~g}$ do al imento $j$ como comprado

$\mathrm{N}_{i j}$ = montante de vitamina ou mineral i na porção comestivel de $100 \mathrm{~g}$ do al imento J como comprado

$R_{c}, R_{p}$ e $R_{i}=$ recomendação de calorias, proteínas, vitaminas ou mineral i.

$\mathrm{P}_{\mathbf{j}}=$ preço de $100 \mathrm{~g}$ do al imento como comprado.

Por esse método, se forem considerados 7 ou 8 vitaminas e minerais, a importância destes em relação à das calorias ou proteínas mudarä de $1 / 7$ para $1 / 8$, o que è uma falha, pois a importância de um nutrien te não deveria depender do número deles num dado estudo.

Outra critica que pode ser feita ao método è a de que numa dada situação podem existir deficiências de vitaminas e minerais e não de calorias e proteínas, de modo que a maior importância dada às calorias e proteínas pela förmula levaria a escolhas não econômicas.

Em resumo, determinados mëtodos de mensuração da contribui ção nutricional dos alimentos falham por não considerar todos os nutrientes essenciais que o alimento provê. Outros, apesar de considerar todos os nutrientes essenciais, dão a eles pesos que podem não ser adequados às vàrias situaçōes existentes. 
Verifica-se assim que tentar calcular dietas de baixo custo atravès de medidas de contribuição nưrricional dos alimentos dificilmente leva a escolhas econômicas.

Desde 1947, quando DANTZI.G desenvolveu o método simplex, tornou-se possivel obter dietas de custo minimo que satisfaçam as recomendaçōes de ingestão diäria de nutrientes sem necessidade da medida da contribuição nutricional.

STIGLER (1945) realizou trabalho pioneiro na årea, obtendo uma dieta que satisfazia às restrições relativas às recomendações de nutrientes. Todavia a dieta obtida não era palatåvel, sendo portanto ina ce i tävel.

SMITH (1959) baseado nos relatörios de compras de 176 fami lias de Lansing, no Estado de Michigan, EUA, elaborou três modelos de programação linear, a fim de determinar dietas adequadas e de custo mínimo.

No primeiro deles pressupunha que se os alimentos eram comumente utilizados, poderiam ser considerados palatäveis e portanto passiveis de serem consumidos. Assim, neste modelo inicial estabelecia restriçōes que objetivavam apenas a sarisfação das necessidades nutricionais. A dieta resultante continha somente seis alimentos e nenhum tempero, tendendo pesadamente para batatas e farinhas.

No segundo modelo, atravès de novas restriçōes, associava à entrada daqueles alimentos que são considerados matẻria prima, não sendo portanto consumidos isoladamente, os seus complementos. Este modelo 
tambèm estabelecia quantidades fixas de condimentos e limites mäximos a certos alimentos que poderiam se tornar tão econômicos que apareceriam em quantidades excessivas.

O terceiro modelo, atravës de um conjunto adicional de res trições, obrigava a dieta a satisfazer alguns häbitos alimentares da população, fixando quantidades mínimas para muitos alimentos que eram amplamente consumidos.

BALINTIFY (1964) desenvolveu uma metodologia para determinar cardāpios de custo mínimo para um período qualquer. Estava preocupado em descobrir a combinação ötima de itens alimentares que satisfizesse os requerimentos nutricionais, estruturais e de variedade numa seqüência de dias. Os requerimentos nutricionais foram estabelecidos a partir das recomendaçōes de ingestão diāria das entidades especializadas no assunto. A variedade por sua vez 'foi conseguida através da "separação por dias" que estabelecia o mínimo de dias ou refeições que deveriam ocorrer antes que o alimento pudesse ser introduzido novamente. Alëm dessas restrições, construíu outras que visavam obter certa variedade de cor e textura numa dada refeição.

SIMÕES (1969), empregando também a programação linear, ela borou värias dietas de custo mínimo para a região de Cristalina, estado de Goiảs, mas seu estudo apresentou falhas em virtude das restriçōes relativas à palatabilidade das referidas dietas serem insuficientes.

DORFMAN et alii. (1958), THEIL et alii (1965), LOPES (1966) e ESTÅCIO (1961) entre outros, realizaram estudos sobre a programação 
linear, sendo um dos aspectos considerados, a sua aplicação no campo da al imentação humana.

FLORENCIO e SMITH (1967), analizaram para a classe trabalhadora da população colombiana, a eficiência da seleção alimentar. Neste estudo, o objetivo não era conseguir dietas de custo mínimo que satís fizessem as recomendaçōes nutricionais, mas sim dietas de custo 'mínimo que proporcionassem as mesmas quantidades de nutrientes consumidas na épo. ca pela população.

A medida de eficiência foi conseguida pelo quociente entre gasto nutricional e gasto total, onde o gasto nutricional se referia ao custo da dieta de custo mínimo e o gasto total ao custo total das dietas consumidas pela população.

Os índices de eficiência foram muito baixos levando os autores à conclusão de que as famílias necessitavam de orientação quanto a seus dispêndios em alimentos.

0 interesse dessa medida de eficiência è teörico, pois a dieta de custo mínimo resultante, em virtude de não ter sido estabelecida a partir também de restriçōes que objetivassem uma maior palatabilidade, torna-se inaceitävel do ponto de vista do consumidor.

Nutricionistas da Comissão Nacional de Alimentação (1959, 1960 e 1961) pesquisando as condições nutricionais de familias vivendo em värias cidades do Rio Grande do Norte, testaram um método de programação dietäria, que apresentou resultados semelhantes ao da programação 
linear. 0 objetivo desses estudos foi calcular dietas suplementares às atuais e não dietas que substituissem as atuais, o que provavelmente torna tais dietas mais facilmente aceitas, pois não implicam em uma mudança radical. Apesar da solução ter custo ligeiramente superior à de custo mínimo, apresenta a vantagem de requerer apenas uma calculadora de mesa, dispensando assim computadores e pesquisadores treinados em programação linear.

Entretanto, não dispõe dos mesmos recursos dạ programação. linear pois näo informa sobre o "preço sombra", nem sobre a estabilidade da solução de custo mínimo face a variaçōes nos preços dos alimentos.

GELPI et alii (1972) compararam cardápios desenvolvidos pe lo método tradicional com os desenvolvidos através da metodologia de $\mathrm{Ba}$ lintify concluindo que:

- o custo dos cardápios obtidos tradicionalmente era cerca de $10 \%$ mais elevado do que os obtidos com a assistência do computador;

- a palatabilidade dos cardápios obtidos por ambos os méto dos era equivalente;

- os niveis nutricionais estabelecidos eram obtidos com maior precisão atravēs do computador.

Numa segunda fase do estudo, elaboraram onze tipos de cardápios especificos a pessoas com determinados problemas clínicos, chegando a conclusões ainda mais favoráveis aos planejados segundo a metodologia de Balintify.

OMETTO et alii (1974) construiram värios modelos de dietas de custo minlmo para a população rural residente na Região de 
Ribeirão Preto. Nos modelos mais sofisticados estabeleceram limites mäximos para todos os alimentos, sendo esses limites calculados através de tabelas de porções alimentares. Todavia, com o objetivo de não obter repetição dos alimentos no almoço e jantar utilizaram como limites porções únicas, o que gerou um nümero de alimentos tão elevado que se tọrnava inviävel a sua ingestão num único dia.

MARTINS ę alii (1977) analizando a relação existente entre consumo alimentar e renda familiar na cidade de lguape, elaboraram. uma dieta de custo mínimo que denominaram dieta padrão (DP), chegando à conclusão de que $20 \%$ e $10 \%$ das familias que consumiam calorias e proteínas respectivamente em faixas insatisfatörias de adequação dispunham de renda suficiente para a aquisição da dieta padrão.

0 ünico problema è que esses níveis suficientes de renda mencionados implicariam'em que as familias utilizassem toda a renda bruta em al imentação, sem considerar que o conjunto de necessidades do homem envolve dispêndios em värios ltens, entre os quais: gastos médicos, manutenção do domicillio, vestuärio, estudos, transportes, etc. Saliente-se que, nem os impostos poderiam ser pagos pelas familias se elas adquirissem a dieta padrão. 
3. MATERIAL E METTODOS

Este trabalho tem dois objetivos bäsicos que exigem metodologias distintas para o seu atendimento. O primeiro deles è a anälise da adequação nutricional da al imentação adquirida pela população paulistana, e o segundo planejar dietas de custo mínimo que satisfaçam as neces sidades nutricionais da referida população.

Inicialmente serä apresentado um breve resumo de algumas características do levantamento e apresentaçāo das informaçōes coletadas pela "Pesquisa de Orçamentos Familiares na Cidade de São Paulo" (POF), no período compreendido entre agosto de 1971 a julho de 1972, que forneceu os dados para o presente trabalho.

A seguir serão examinados os modelos de anälise da adequação nutricional da alimentação adquirida e da obtenção das dietas de custo mínimo. 
3.1. Características do levantamento e apresentação dos dados da Pesquisa de Orçamentos Familiares na Cidade de São Paulo - (POF).

A finalidade principal da POF foi atualizar a estrutura de ponderação e de levantamento de preços para o cålculo do indice de custo de vida no município de São Paulo. Para isso, foram coletados dados referentes à estrucura do consumo em termos de quantidades e dispêndios, alèm dos relativos às principais características sōcio-econômicas das famílias constituintes da amostra. Para os objetivos desta pesquisa interessam as informaçōes referentes às quantidades consumidas e dispêndios com alimentos e à composição da população por idade e sexo.

Na POF foram consideradas como familias o "conjunto de pes. soas que vivem juntas, na dependência de um orçamento doméstico, isto é, que reunem suas receitas e as retiram para fazer face às despesas de um fundo comum. Pertencem ao grupo: o "chefe", sua mulher, filhos(as) solteiros residentes (com ou sem renda pröpria), filhos(as) casados(as), des quitados(as) ou viuvos(as), parentes ou "agregados", desde que vivam às expensas do grupo ou concorram para o orçamento comum". ㄴ

0 instrumento de coleta de dados foi o questionärio e a unidade bäsica de levantamento o mes, sendo os dados apresentados em termos mensais, média do período agosto de 1971 a julho de 1972.

I/ KIRSTEN, J.To e outros (1973) - Orçamentos Familiares na cidade de são Paulo Série IPE - MONOGRAFIAS - São Paulo. 
Para a seleção de um domicilio em particular, num primeiro estägio selecionou-se uma àrea (um livro de leitura da Light), e dentro desta o número de domicilios necessärios à pesquisa.

0 nümero de äreas selecionadas foi de 100, correspondendo às àreas de nümeros pares das 200 que constituem o "Amostrão", que por sua vez provieram de estratos geográficos e foram selecionadas em probabi lidades proporcionais ao nümero de domicillios em cada ärea.

A amostra sorteada foi de 3202 domicilios, mas em virtude de aparecerem dentro dela estabelecimentos comerciais e industriais que tiveram de ser retirados, e "domicilios surpresas" (mais de um domicilio sob o mesmo registro de consumo de luz ou mais de uma familia sob o mesmo teto), o nümero final foi de 2380 domicilios.

Como indicaçōes de boa qualidade dos dados coletados, temse as seguintes:

a) mostraram-se extremamente semelhantes aos obtidos em pesquisa semelhante realizada pela COCEA/PUC no Estado do Rio de Janeiro;

b) a consistência interna dos dados foi medida através da comparação entre o agregado das despesas em al imentação com häbitos de compra por classe de renda, sendo os resultados encontrados novamente mu to semelhantes.

As informações foram coletadas por domicillio mas apresenta das agrupadas em quatorze classes de renda familiar. 
A Tabela 2 mostra como se achava estratificada a amostra segundo o critério de renda familiar.

Tabela 2. Estratificação da População Amostrada segundo a Renda Familiar

\begin{tabular}{|c|c|c|c|c|c|c|}
\hline $\begin{array}{l}\text { Classe } \\
\text { de } \\
\text { Renda }\end{array}$ & $\begin{array}{l}\text { Renda } \\
\text { Total }\end{array}$ & $\begin{array}{l}\text { Intervalo } \\
\text { de renda } \\
\text { familiar I/ }\end{array}$ & $\begin{array}{l}\text { No } \\
\text { de } \\
\text { Quest. }\end{array}$ & $\begin{array}{l}\text { Renda } \\
\text { familiar } \\
\text { mensal } \\
\text { mëdia }\end{array}$ & $\begin{array}{l}\text { No de } \\
\text { Indivi- } \\
\text { duos }\end{array}$ & $\begin{array}{l}\text { Renda } \\
\text { "Per } \\
\text { Capita" }\end{array}$ \\
\hline 1 & 6179,83 & $0-1$ & 34 & 181,76 & 99 & 62,42 \\
\hline 2 & 61879,30 & $1-2$ & 172 & 359,76 & 572 & 108,18 \\
\hline 3 & 422332,75 & $2-4$ & 615 & 686,72 & 2462 & 171,54 \\
\hline 4 & 560520,78 & $4-6$ & 502 & 1116,58 & 2269 & 247,03 \\
\hline 5 & 473854,42 & $6-8$ & 302 & 1569,05 & 1397 & 339,19 \\
\hline 6 & 380336,76 & $8-10$ & 189 & 2012,36 & 938 & 405,47 \\
\hline 7 & 321177,08 & $10-12$ & 129 & 2489,74 & 613 & 523,94 \\
\hline 8 & 305315,03 & $12-14$ & 103 & 2964,22 & 486 & 628,22 \\
\hline 9 & 177364,66 & $14-16$ & 53 & 3346,50 & 229 & 774,51 \\
\hline 10 & 217095,91 & $16-18$ & 56 & 3876,71 & 262 & 828,61 \\
\hline 11 & 174787,67 & $18-20$ & 41 & 4263,11 & 206 & 848,48 \\
\hline 12 & 128361,09 & $20-22$ & 27 & 4754,11 & 144 & 891,39 \\
\hline 13 & 553969,74 & $22-33$ & 96 & 5770,52 & 426 & 1300,39 \\
\hline 14 & 691942,67 & 33 ou + & 61 & 11343,32 & 315 & 2196,64 \\
\hline
\end{tabular}

I/ Intervalo de renda familiar em termos do salärio mínimo médio do perío do 1971/72 sendo, salário mínimo $1971=225,60$ (agosto/abril: $225,60 \times 9$ ) e salärio mínimo $1972=268,80$ (maio/julho: $268,80 \times 3$ ), logo

salärio minimo médios $225,60 \times 9+268,80 \times 3$

Fonte: POF-IPE/USP. 
o critërio utilizado para a estratificação da população amostrada, que foi o da renda familiar e não o da renda familiar "per capita", ocasionou que o tamanho da famillia não fosse constante nas värias classes de renda. Nos intervalos de renda mais baixa, a renda familiar é diretamente proporcional ao nümero de pessoas que trabalham por familia, que por sua vez guarda relação direta com o tamanho desta, conforme podese verificar na Tabela 3 .

Tabela 3. Habitantes e Pessoas que Trabalham por familia nas

Diversas Classes de Renda

\begin{tabular}{|c|c|c|c|}
\hline \multirow{2}{*}{$\begin{array}{c}\text { Classe de } \\
\text { Renda }\end{array}$} & Habitantes & \multicolumn{2}{|c|}{ Pessoas que Traba- } \\
\hline & por familia & I ham & por familia \\
\hline 1 & 2,91 & & 0,79 \\
\hline 2 & 3,32 & & 0,83 \\
\hline 3 & 4,00 & & 1,33 \\
\hline 4 & 4,51 & & 1,71 \\
\hline 5 & 4,62 & & 1,97 \\
\hline 6 & 4,96 & & 2,16 \\
\hline 7 & 4,75 & & 2,14 \\
\hline 8 & 4,71 & & 2,12 \\
\hline 9 & 4,32 & & 1,94 \\
\hline 10 & 4,67 & & 2,01 \\
\hline 11 & 5,02 & & 2,41 \\
\hline 12 & 5,33 & & 2,11 \\
\hline 13 & 4,43 & & 1,90 \\
\hline 14 & 5,16 & & 2,32 \\
\hline
\end{tabular}


Esta variação no tamanho da famillia tornou necessärio o cálculo das necessidades nutricionais das familias médias representativas de cada classe de renda, pois o estabelecimento das necessidades de uma familia média geral a todas as classes implicaria numa superestimativa das necessidades das familias dos intervalos de renda mais baixa.

\subsection{Adequação nutricional da al imentação da população paul istana,}

\subsubsection{Informação bảsica}

Para calcular a adequação nutricional da alimentação adqui rida por uma população, necessita-se inicialmente estabelecer quais são suas necessidades nutricionais e a seguir calcular as quantidades adquiri das de nutrientes atravēs dos alimentos consumidos e respectivas composições químicas.

3.2.1.1. Necessidade nutricional da população

Para determinação da necessidade nutricional da população computaram-se as necessidades nutricionais dos componentes de cada classe de renda, as quais divididas pelo nümero de familias no estrato forneceram as necessidades da familia média representativa de cada classe.

Para a energia e nutrientes incluidos neste estudo utilizaram-se as recomendações da Food and Agriculture Organization, World Heal th Organization (FAO/WHO), revisadas em 1974 e adaptadas para a temperatura mëdia anual da região2/.

27De acordo com as informaçōes do Sétimo Distrito Meteorolögico a temperatura média na cidade de São Paulo nos meses em estudo foi de 19,025:C. 
Optou-se por essas recomendações devido a seu carater universal, ou seja, não se referem à uma população especifica, sendo suficientes para a manutenção da saüde em aproximadamente todas as pessoas (FAO: 28/WHO: 61) 3 '.

As necessidades calöricas e de nutrientes variam sobretudo, em função da idade, sexo, pesa $\$$ /, atividade $5 /$ e clima.

Cumpre ressaltar que essas recomendações são para indivi iduos saudãveis, não tendo sido efetuado nenhum exame clínico na população amostrada para posterior estabelecimento das necessidades nutricionais.

3/ As recomendações de ingestão diäria de nutrientes são superiores às ne cessidades de uma pessoa média em virtude de considerarem as variaçōes individuais. Isto não ocasiona nenhum problema pois, no caso da proteîna, qualquer excesso de ingestão não requerida pelo organismo será ut ilizado como fonte de energia, o de vitaminas hidrosolúveis excreta do na urina, o de retinol armazenado no fígado e o de cálcio e ferro não absorvido no intestino.delgado ou el iminado nas fezes. Todavia, em relação à energia como não hã nenhuma forma do organismo el iminar o ex cesso, as recomendações referem-se à ingestão energética adequada a a uma pessoa média numa categoria especificada, pois caso fossem maiores para considerar as variaçōes individuais, a pessoa média que as ingerisse passaria a engordar.

4/ Como os individuos amostrados não foram pesados, não foi feita nenhuma modificação nas recomendações de ingestão diăria da FAO/WHO.

5/ Apesar da atividade física desenvolvida pelos individuos ser um fator importante na determinação das necessidades calóricas, numa população heterogênea como é a paul istana encontram-se indivíduos com atividades extremamente variadas - desde a sedentäria até os com atividade física intensa. Assim considerou-se como é feito nas recomendaçōes da FAO/ OMS, que a atividade média da população é moderada, ou seja, a pessoa média distribui as 24 horas diárias da seguinte maneira: 8 horas em uma ocupação que envolva atividade moderada, 8 horas na cama, 4-6 horas sentada ou em atividade leve, 2 horas andando, em recreação ativa ou deveres domésticos. 
Caso houvessem sido consideradas as infecçōes, as sindromes de mä absorção, etc., que estão provavelmente presentes na população, as recomendaçōes teriam de ser alteradas, uma vez que o organismo debilitado necessita de doses suplementares dos diversos nutrientes.

As recomendações de ingestão diäria de energia e nutrientes podem ainda variar dependendo de outros fatores. 0 grupo misto FAO/ WHO, levando isso em consideração estabelece, para alguns nutrientes, recomendações em intervalos, sendo que o pesquisador escolhe o valor que. considera mais apropriado para a população em estudo.

No presente caso foram considerados os seguintes valores:

a) Energia (quilocalorias)

As recomendações energēticas do grupo misto FAO/WHO são apropriadas para a temperatura mèdia anual de 10:C. Para cada 10:C acima da temperatura de referência recomenda-se um decréscimo de $5 \%$ nas ingestões. Como a temperatura média no ano em questão na região paulistana foi de 19,025:C efetuaram-se reduções de 4,5\% nas recomendações.

b) Proteinas (gramas)

As recomendações variam em função da qualidade da proteína da dieta. 0 grupo FAO/WHO no informe FAO: $37 /$ WH0:301 recomenda que se considere a "net protein utilization" (NPU) 6/ dos paises subdesenvolvidos entre 50 e 60; dos paises em desenvolvimento entre 60 e 70 e dos paises desenvolvidos entre 70 e 80 . Para a população em estudo optou-se pelas

6/ A NPU expressa a digestibilidade e o valor biolögico da mistura de ami noäcidos absorvidos no intestino. Indica a proporção do nitrogênio in= gerido que é retido. 
recomendações que consideram o NPU igual a 60 .

c) Cálcio

Utilizaram-se os limites inferiores das recomendaçōes seguindo a sugestão feita nos informes FAO: 28/WHO: 61 .

\section{d) Ferro}

Como as recomendações variam em função da porcentagem das calorias que procedem de alimentos de origem animal ou vegetal, por medida de precaução utilizaram-se as recomendações nos seus limites superiores, ou seja, suficientes mesmo que menos de 10 por cento das calorias provenham de alimentos de origem animal.

d) Retinol

Utilizaram-se as recomendações do grupo FAO/WHO, sem neces sidade de nenhuma consideração a respeito da proporção de $\beta$-caroteno e outros carotenoides na dieta, pois, na tabela de composição química dos alimentos usada, esses elementos estão em termos de retinol.
f) Tiamina
A ingestão recomendada è em função do nümero de calorias, sendo de $0,40 \mathrm{mg} / 1000 \mathrm{kcal}$.
g) Niacina

A ingestão recomendada $\dot{e}$ de 6,6 equivalentes de niacinal $1000 \mathrm{kcal}$.

h) Riboflavina

A ingestão recomendada ē de $0,60 \mathrm{mg} / 1000 \mathrm{kcal}$. 
i) Acido ascörbico

As recomendações variam de 20 a $30 \mathrm{mg} /$ dia conforme a faixa etäria.

Não foram coletadas pela POF informações sobre o nümero de gestantes e lactantes. Como ambos os grupos requerem complementação nutricional, seguiu-se a metodologia recomendada no informe FAO:52/WHO: 322 que estabelece que para se estimar o número de gestantes numa população, deve-se considerar o nümero de crianças menores de um ano e acrescentarse $10 \%$ para levar em consideração a taxa de mortalidade infantil. Como só se recomendam acrēscimos nutricionais na segunda metade de gestação divide-se esse nümero por dois estimando-se assim o nümero de gestantes que se encontram na segunda metade da gestação.

Para estimar o número de lactantes numa população, recomenda-se considerä-lo igual ao nümero de crianças com idade entre 0 e 6 meses de idade.

As ingestões recomendadas de nutrientes por faixa etäria à temperatura média anual 19,025:C, encontram-se na Tabela 4.

A partir das informações apresentadas nesta tabela calculam-se as necessidades mensais de energia e nutrientes da população pertencentes à cada classe de renda, que divididas pelo número de famillias presente em cada uma constituem as necessidades nutricionais mensais da famil ia média de cada estrato de renda. 
28.

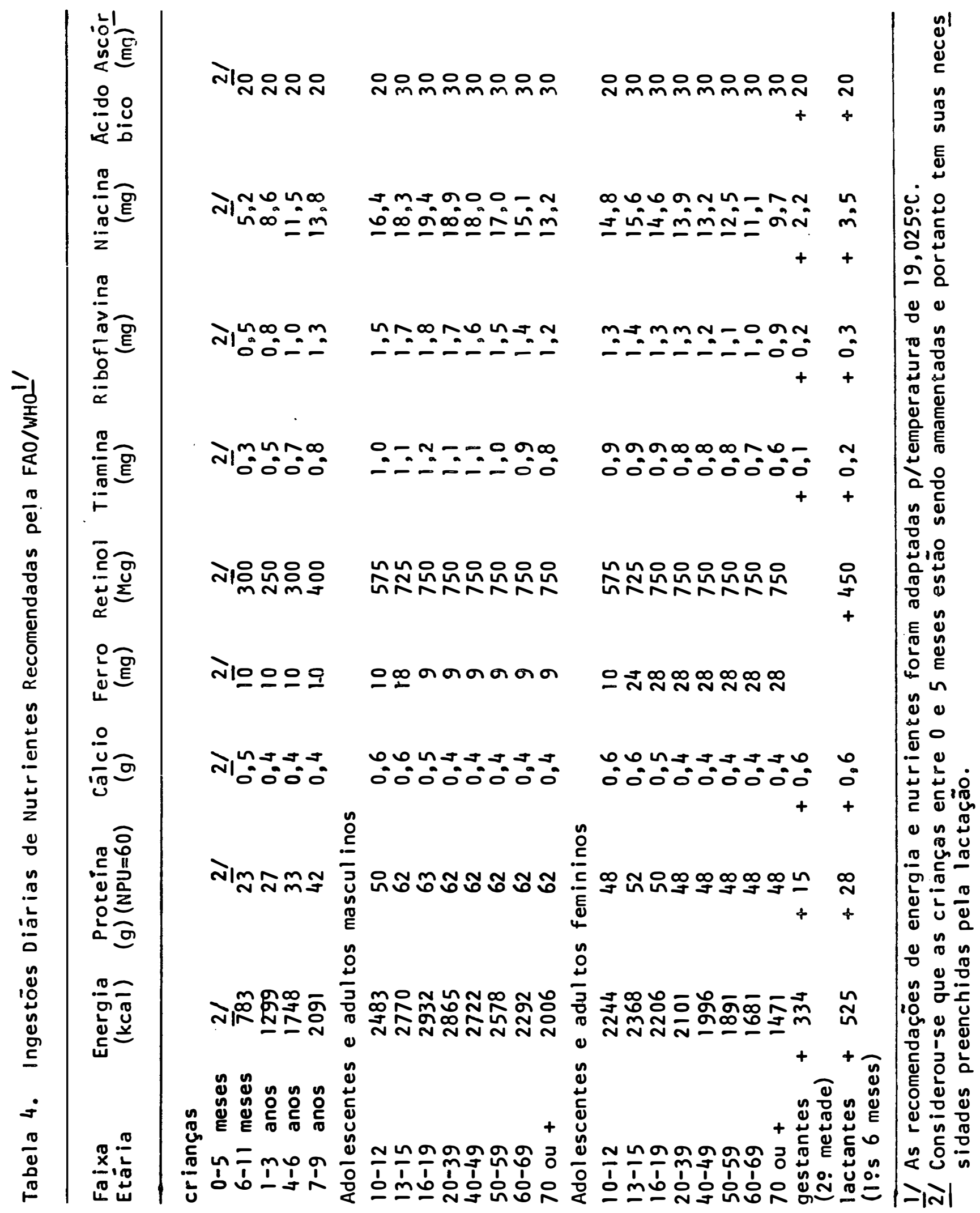


3.2.1.2. Teor de nutrientes da al imentação adquirida.

Para obter o teor de nutrientès de uma al imentação necess ta-se conhecer a sua composição em termos de $100 \mathrm{~g}$ de alimentos e a quanti dade de nutrientes contida nesses al imentos.

Neste trabalho seră considerada sempre a disponibilidade de nutrientes ao invës de consumo de nutrientes, pois a Pesquisa de Orçamentos familiares (POF) tendo por objetivo a reformulação de indice dé custo de vida no municipio, levantou apenas dados sobre as despesas realizadas no mes anterior pelas familias entrevistadas, não considerando os estoques de alimentos existentes nos domicilios e/ou estoques formados com a compra realizada no período. Alèm disso, não foram obtidas informa ções sobre sobras de al imentos nos pratos. Portanto os dados disponiveis são sobre "compra de alimentos" e não sobre "consumo de al imentos".

3.2.1.2.1. Transformação das quantidades de alimentos para a unidade de cem gramas

Essa transformação foi necessäria em virtude das tabelas de composição química de alimentos fornecerem o teor de nutrientes contido em $100 \mathrm{~g}$ de al imentos.

Quando a unidade de compra mencionada foi o quilograma(kg) a transformação da quantidade adquirida em cem gramas foi direta, mas para grande parte dos alimentos a unidade foi diferente. 
Assim, para as hortaliças e frutas a unidade mencionada foi frequentemente o pē, a dúzía ou a unidade. Os seus respectivos pesos assim como das dúzias de ovos de diferentes tamanhos foram obtidos no Ins tituto de Economia Agrícola da Secretaria da Agricultura do Estado de São Paulo.

As densidades dos värios tipos de öleos comestiveis foram encontradas em MICHAEL e BAILEY (1951) e a partir delas transformaram-se as informações de volume (litro) para cem gramas.

As densidades das bebidas alcoölicas foram encontradas em ALMEIDA (1940).

0 peso da cerveja e refrigerantes contidos nos värios tamanhos de vasilhame foram obtidos através da pesagem direta.

As densidades do leite B e C foram conseguidas através do teor de gordura especifico de cada tipo.

Para o leite em pō, margarina, massa de tomate, maizena, chocolate em pó, caldo de carne, sardinha em lata e palmito em lata, obti veram-se as respectivas transformações em grama no pröprio Banco de Dados do Instituto de Pesquisas Econômicas (IPE) da Universidade de São Paulo.

El iminaram-se os dados sobre compra de alguns alimentos por não ter sido possível a conversão em grama, em virtude de estarem, ca da um, disponiveis no mercado em embalagens de värios tamanhos e não se dispor de informações que possibilitassem a ponderação. São eles: cōco ra lado, sorvete, licores, café solüvel, gordura vegetal, farinha láctea, 
queijo ralado, uva passa, figos secos, panetone, abacaxi em calda, ameixa seca, molho de pimenta, maionese, feijoada, atum em lata, pães especiais, pão doce, rosca e chã. No total eles perfazem $0,17 \%$ dos gastos em alimen tação no domicillio.

Os dados dos pesos em cem gramas das unidades de compra de todos os alimentos para os quais foi possivel a transformação encontramse no apêndice 1 .

3.2.1.2.2. Composição química dos al imentos

Utilizou-se a "Tabela de Composição Química dos Alimentos" de OMETTO et alii. (1977) pois embora seja uma compilação de outras? apre senta as seguintes modificaçōes:

- em relaçāo à vitamina $A$, fornece a composição em termos de retinol e não de elementos com atividade de vitamina $A$ como as demais, sendo que as recomendações dietárias são em retinol;

- em relação à niacina, apresenta a composição em equivalentes de niacina, ou seja, considera a prë-formada e a derivada do triptofano e não apenas a prë-formada como as demais sendo que as recomendaçōes dietärias são em equivalentes de niacina.

If Tabla de Composicion de Alimentos para uso em America Latina (INCAPICNND)

- Composition of Foods - Agricultures Handbook n? 8

- Tabela de Composição Quimica e do Teor Vitamínico dos Alimentos de Guilherme Franco

- Dados compilados de Diferentes Tabelas de Composição Química dos Ali mentos, Faculdade de Higiene e Saúde - USP. 
Efetuaram-se nessa tabela dois grupos de alteraçōes com o objetivo de considerar a porção não comestivel dos alimentos e as perdas nutricionais ocorridas durante a cocção, ou seja:

a) Al teraçōes efetuadas para considerar a porção não comes tivel dos al imentos.

As informações contidas na POF referem-se à quantidades brutas. Portanto, depois de transformarem-se todas as informaçōes de com pra em termos de $100 \mathrm{~g}$ ainda não se podia utilizar os dados da "Tabela de Composição Quimica dos Alimentos" pois estes se referem a $100 \mathrm{~g}$ comestiveis do al imento e aqueles a $100 \mathrm{~g}$ como são comprados sem descontar sua parte não comestivel.

Assim alteraram-se os dados da tabela para considerar esse fator.

Por exemplo, as modificações efetuadas na composição química da banana maçã foram as seguintes:

$100 \mathrm{~g}$ (bruta) de banana maçã contém $22 \mathrm{~g}$ de porção não comestivel compreendida pela casca. Assim, se $100 \mathrm{~g}$ bruta corresponden a $78 \mathrm{~g}$ comestiveis, as quantidades de nutrientes disponiveis em $100 \mathrm{~g}$ comestiveis deverão ser multiplicadas por 0,78 para se ter a composição de $100 \mathrm{~g}$ de banana maçã como comprada.

Os al imentos que não tem porção não comestivel, tais como - açūcar, o arroz, o leite, etc... permaneceram lögicamente com a mesma compos ição. 
b) Alterações efetuadas para considerar as perdas nutricionais ocorridas durante a cocção.

A tabela utilizada fornece para todos os alimentos, com ex ceção de alguns industrializados, a composição da forma crua. Entretanto não se puderam utilizar tabelas de composição de alimentos apös a cocção, por não haver informações seguras sobre as alteraçōes de peso ocorridas nesse processo para a maior parte dos al imentos. Isto impossibilita que se descubra o preço de $100 \mathrm{~g}$ deles jä preparados, dado que seria necessärio para a elaboração de dietas de custo mínimo caso se utllizassem essas tabelas.

Para contornar o problema das perdas nutricionais ocorridas, transformou-se a composição quimica dos alimentos que somente poderiam ser consumidos após cozidos, utilizando-se os dados da Tabela 5.

Tabela 5. Porcentagem de Perdas dos Nutrientes Ocorridas Durante a Cocção Nutrientes $\%$ de Perdas

Proteina 0

Ferro $11,8-13,6$

Retinol $10-30$

Tiamina $25-45$

Riboflavina $0-48$

Niacina $0-72$

Ácido Ascörbico $20-80$

Fonte: OMETTO et al ii (1977) Tabela de Composicão Quimica dos Al imentos, Depto. de Tecnologia dos Alímentos, ESALQ/USP - Piracicába. 
Essas perdas são fornecidas em intervalos, em virtude das diferentes reaçōes dos nutrientes aos mêtodos de cocção, tempo de exposição à luz e oxigênio, e ao pH da solução.

Nesta pesquisa consideraram-se os valores médios dos inter valos.

Não se obtiveram informaçōes sobre perdas ocasionadas pela cocção para o cālcio.

A tabela resultante das alteraçōes especificadas nos itens "a" e "b" apresentados, encontra-se no apêndice 2.

Não se conseguiu a composição nutricional dos seguintes alimentos: bolos e tortas, gelatinas, geléia, pudim, doces de confeitaria, batata frita, amendoim, artigos para feijoada, suco de frutas, "Q.suco", molho de mostarda, erva-doce, jiló, ovos de codorna, nabo, fermento em pó, sopas e frutas cristalizadas. No total eles perfazem $0,11 \%$ dos gastos em alimentação no domicillio.

3.2.1.2.3. Cálculo da quantidade de nutrientes fornecida pela al imentação

As quantidades de nutrientes foram obtidas através da multiplicação das quantidades de alimentos adquiridos pela população de cada classe de renda (calculadas segundo o procedimento descrito em 3.2.1.2.1) pelos nutrientes contidos nesses mesmos alimentos (calculados usando a ta bela obtida através do procedimento descrito em 3.2.1.2.2). A seguir foram divididas pelo numero de familias que constituem cada classe de 
renda para se obter o teor de nutrientes da alimentação por familia.

Desprezou-se, no călculo dos nutrientes adquiridos pela população, $0,28 \%$ dos gastos em al imentação domiciliar por serem constituí dos de alimentos para os quais não se conseguiu a transformação em peso $(0,17 \%)$ ou a composição quîmica $(0,11 \%)$. Mais grave foi não poder incluir no cômputo dos nutrientes adquiridos aqueles provenientes da alimen tação efetuada fora do domicillio, pois somente se levantaram informaçōes sobre o gasto efetuado e não sobre o tipo de alimentação feita. Esses gas tos perfazem $10,76 \%$ dos gastos em al imentação. Todavia nos primeiros estratos de renda que interessam logicamente mais, essa porcentagem ë menor variando de $1,14 \%$ à $10,40 \%$.

3.2.2. Adequação nutricional da al imentação

A adequação nutricional foi calculada por classe de renda, a partir da comparação das calorias e nutrientes adquiridos pela população amostrada, com as necessidades nutricionais estabelecidas.

Serả apresentada em intervalos em virtude de que värios dos al imentos adquiridos poderiam ter sido consumidos crús ou cozidos, podendo ter portanto, contribuições nutricionais diferentes. Assim, os niveis de disponibilidade de consumo de nutrientes oscilam no intervalo com preendido entre os niveis $A$ e $B_{0}$ sendo:

Nivel A - Compreendido pela soma dos nutrientes derivados dos alimentos que são consumidos apenas na forma crua, com os derivados dos al imentos que são consumidos apenas na forma cozida, com derivados 
dos alimentos que podem ser consumidos de ambas as maneiras considerandose que foram consumidos cozidos.

Nivel B - Compreendido pela soma dos nutrientes derivados dos alimentos que são consumidos apenas na forma crua, com os derivados dos al imentos que são consumidos apenas na forma cozida, com os derivados dos alimentos que podem ser consumidos de ambas as formas considerandose que foram consumidos crūs.

Os indices de adequação nutricional são obtidos dividindose as disponibilidades de nutrientes pelas respectivas recomendaçōes. Como para proteínas a perda decorrente da cocção è praticamente nula e para energia e cálcio não foram encontradas informaçōes a respeito, para esses nutrientes a adequação serä fornecida em valores fixos.

\subsection{Călculo das dietas de custo mínimo.}

3.3.1. Informações bäsicas

Para se obter as dietas de custo minimo necessitam-se das seguintes informaçōes:

3.3.1.1. As necessidades nutricionais da população.

Essas necessidades foram estabelecidas durante o cälculo da adequação nutricional e se encontram na Tabela 7 a ser apresentada no pröximo capitulo. 
3.3.1.2. Os alimentos disponiveis e respectivos preços

Consideraram-se al imentos disponiveis os adquiridos na épo ca pela população.

Os preços de $100 \mathrm{~g}$ dos alimentos foram obtidos através da divisão dos gastos (em $(r \$$ ) pelas respectivas quantidades transformadas em $100 \mathrm{~g}$ dos al imentos adquiridos e encontram-se no apêndice 1.

3.3.1.3. Composição química dos alimentos

Utilizou-se a mesma tabela usada no cāiculo da adequação nutricional e que estä no apêndice 2.

3.3.1.4. Hăbitos al imentares da população

Estas informações tambēm se fizeram necessärias para que obtivessemos dietas mensais adequadas no aspecto nutricional, e que possibilitassem, através da distribuição dos alimentos nos värios dias do mes, a obtenção de cardápios estruturados de acordo com hábitos alimentares da população amostrada, palatāveis, com variedade razoāvel e adequadamente condimentados.

Estas informaçōes foram obtidas através dos dados de compras mensais de alimentos por familia de cada classe de renda.

3.3.2. Instrumental analitico

3.3.2.1. Os métodos grä́icos 
3.3.2.1.1. 0 modelo de apenas dois alimentos e um nümero il imitado de restrições nutricionais.

Supondo-se que estão disponiveis os al imentos $X$ e $Y$ e se deseja obter a combinação de custo mínimo que satisfaça as recomendaçōes dietärias especificadas de energia, tiamina e riboflavina.

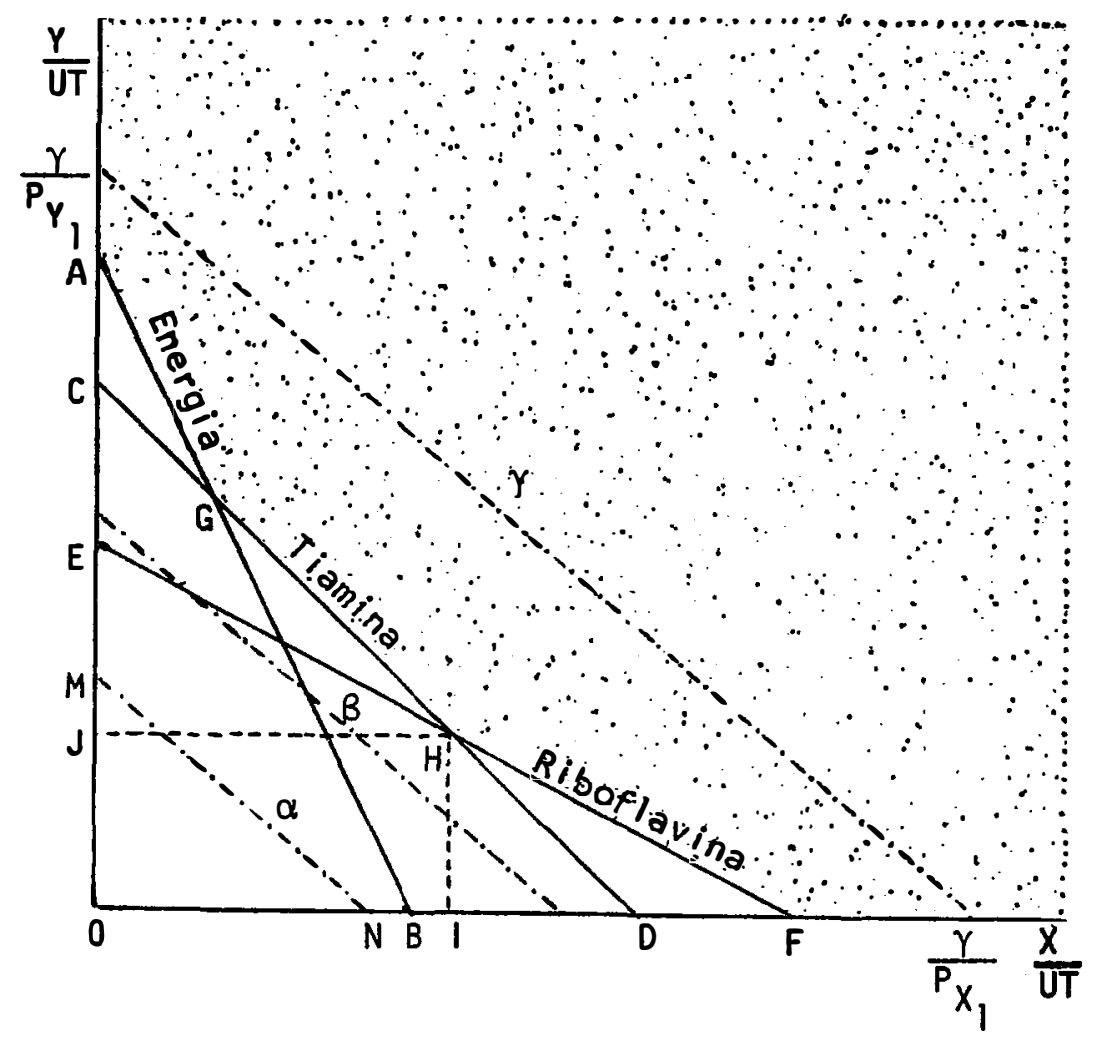

Na Figura I tem-se:

$O A=$ quantidade do al imento $Y$ que fornece 0 montante calorico igual ao estipulado pelas recomendações desse nutriente.

$$
O B=\text { quantidade do al imento } X \text { necessärio para } 0 \text { mesmo pro- }
$$

pósito. 
Portanto verifica-se que os alimentos $X$ e $Y$ podem servir como substitutos a uma taxa constante determinada pela proporção do conteüdo calörico de $X$ em relação ao de $Y$. A linha $A B$ mede a taxa de substi tuição e qualquer combinação alimentar ao longo dessa linha atenderā aos requerimentos calöricos.

Da mesma forma pode-se satisfazer as recomendaçōes da tiamina ao longo da linha CD e de riboflavina em EF.

As recomendações dos três nutrientes serão atendidas simultaneamente nos pontos sobre ou à direita da linha AGHF, sendo esta con siderada por SMITH (1964) como o limite inferior da "região de indiferença'"l/ (representada pela àrea hachureada) na qual qualquer combinação de al imentos representa um meio igualmente satisfatório de atender os objeti vos especificados.

0 problema è escolher a combinação aceitävel no aspecto nutricional e que implique em menor custo.

Logicamente ela deverä estar ao longo da linha AGHF, pois qualquer outra situada à sua direita, embora nutricionalmente aceitāvel, será mais cara por incluir quantidade maior de pelo menos um alimento.

Admitindo-se que se dispōe de uma quantia " $\gamma$ " para ser gasta em alimentação e sendo $P_{x l}$ e $P_{y l}$, respectivamente, os preços dos

8/ DORFMAN et alii (1958) enfatizam que este não è um mapa de indiferença no sentido usual por não estar implícita no problema a escala de preferências do consumidor. 
alimentos $X$ e $Y$, adquirindo-se somente um alimento, obter-se-ä $\frac{Y}{P}$ unidades de $X$ ou $\frac{Y}{P_{Y l}}$ unidades de $Y$.

Na Figura I, a reta que une esses dois pontos pode ser cha mada linha de orçamento, de isocusto ou das combinaçōes possíveis. Todos os pontos ao longo ou abaixo dela representam combinações al imentares que podem ser adquiridas com no måximo $\gamma$ cruzeiros, que foi a quantia monetäria estipulada.

As linhas de isocusto $\alpha$ e $\beta_{0}$ paralelas a $\gamma$, mostram diferentes combinaçōes al imentares que poderão ser adquiridas com menor dispēndio, desde que os preços de $X$ e $Y$ permaneçam constantes.

A combinação alimentar de custo minimo que satisfaz as restriçōes nutricionais estipuladas serä obtida no ponto de tangência de uma das linhas de isocusto com a curva de indiferença $9 /$. No presente caso ela compreenderå 01 unidades de $X$ e OJ de $Y$.

Alterações nos preços dos alimentos irão modificar essa combinação al imentar por alterar a inclinação das linhas de isocusto.

Esta anälise pode ser estendida a um nümero maior de restrições nutricionais mas dificilmente poderä ser visualizada graficamente para mais de dois al imentos.

9/ Poderia acontecer que a quantia monetäria disponivel fosse insuficiente para comprar as quantidades dos al imentos que fornecesse os nutrien tes aos níveis estipulados. Neste caso o modelo não teria utilidadé pràtica. 
3.3.2.1.2. 0 modelo de apenas duas restriçōes nutricionais e nümero ilimitado de al imentos.

Supondo-se que se deseja obter uma dieta de custo mínimo que satisfaça recomendações dietárias especificadas de energia e proteína sendo esses nutrientes contidos em trēs alimentos representados na figura 2 pelas linhas $A_{1}, A_{2}, A_{3}$, em quantidades especificadas pelas suas coordenadas.

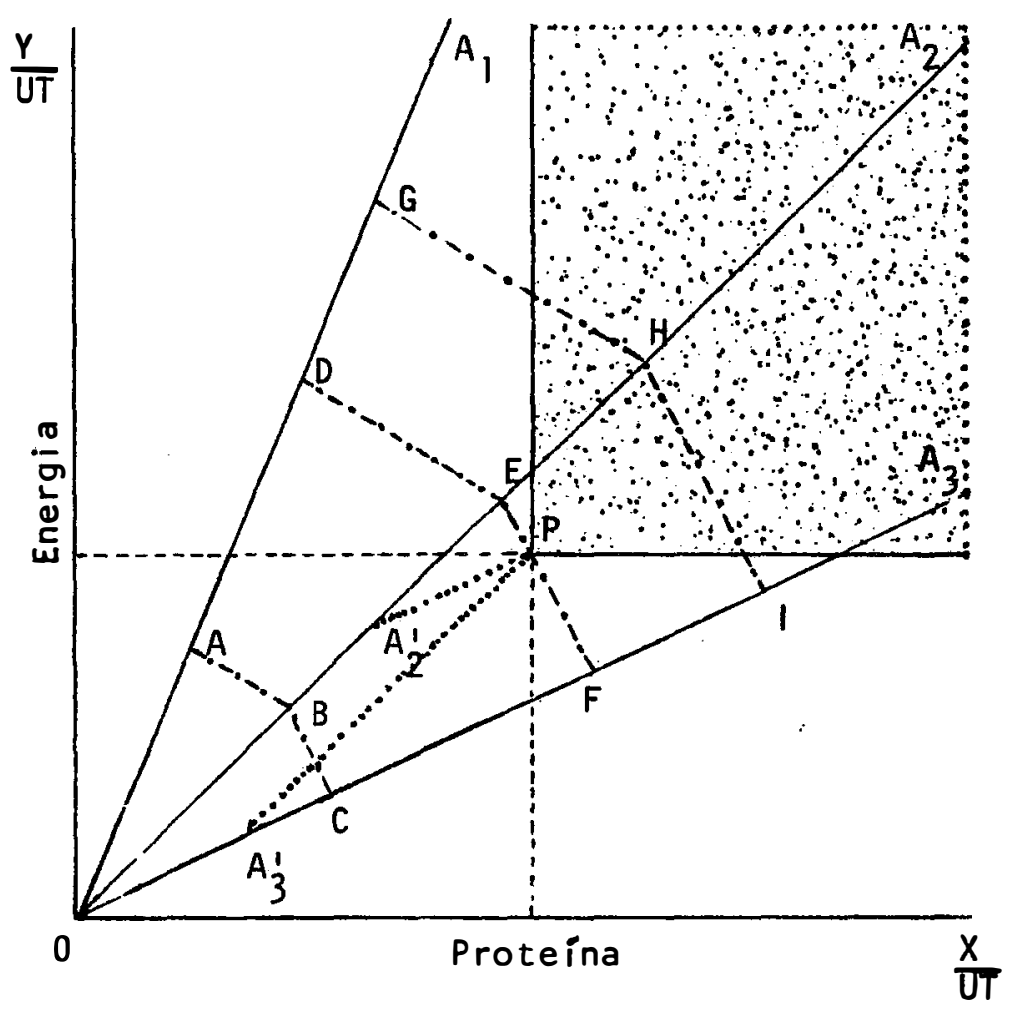

Na figura 2, a ärea hachureada representa a região na qual qualquer combinação alimentar fornece ao menos o montante de proteína e energia estipulado nas recomendações dietãrias. 
Ela pode tambèm ser considerada, utilizando-se 0 mesmo raciocinio empregado no modelo anterior, uma "renião de indiferença" na qual qualquer combinação al imentar representa um meio igualmente satisfatório de atender aos objetivos nutricionais.

As linhas $A B C$, $D E F$ e $G H I$ são linhas de isocusto e mostram as diferentes quantidades dos alimentos que podem ser adquiridas $\operatorname{com} \alpha, \beta$ eY cruzeiros respectivamente. Logicamente, se, por exemplo, $\beta=2 \alpha$,. dispêndio de $B$ cruzeiros no al imento $A_{1}$ deverá proporcionar o dobro dos nutrientes adquiridos com $\alpha$ cruzeiros do mesmo al imento.

A combinação alimentar de custo minimo que satisfaz as recomendações dietárias è a representada pelo ponto $P$.10/ Qualquer outra situada nas coordenadas ou na ärea hachureada (ünicas aceitäveis no aspecto nutricional) implicam em um custo maior, por se colocarem em linhas de isocusto mais distantes da origem.

Como esse ponto está numa linha de isocusto que une os ali mentos $A_{2}$ e $A_{3}$ indica que a citada dieta será constituida desses dois al mentos em quantidades que são obtidas traçando-se paralelas às linhas $A_{2}$ e $A_{3}$ a partir do ponto $P$. Tais quantidades estão indicadas na figura 2 por $O A_{2}^{\prime}$ do al imento $A_{2}$ e $O A_{3}^{\prime}$ de $A_{3}$.

Esta anālise pode ser estendida a um nümero maior de alimentos desde que se permaneça apenas com dois nutrientes.

10/ Novamente poderia acontecer da quantia monetäria disponivel ser Insuficiente para adquirir a combinação alimentar representada pelo ponto P. Neste caso o modelo não teria utilidade prática. 


\subsubsection{0 modelo matemätico}

Somente pode-se obter a combinação de custo minimo atravës do método grä́fico quando se dispōe de apenas dois alimentos e um nümero ilimitado de restrições nutricionais ou duas restrições nutricionais e um nümero ilimitado de al imentos.

Na prätica estas situações dificilmente ocorrem.

O geral é ter-se de obter uma dieta de custo minimo atra-. vès de um nümero relativamente elevado de al imentos e que preencha as ne cessidades de mais de dois nutrientes.

Faz-se então necessārio o uso de expressões matemāticas pạ ra solucionar problemas desse tipo.

Algebricamente, o modelo da programação linear aplicada ao cälculo de dietas pode ser representado da seguinte forma:

$$
\begin{aligned}
& \text { Minimizar a função objetivo: } \\
& z=c_{1} x_{1}+c_{2} x_{2}+\ldots+c_{n} x_{n}
\end{aligned}
$$

onde:

$$
\begin{aligned}
& z=\text { custo da dieta } \\
& c_{j}=\text { custo unitärio do al imento } j \\
& x_{j}=\text { quantidade ao al imento } j \text { na dieta } \\
& n=n \text { o de al imentos }
\end{aligned}
$$


44.

Sat isfazendo às seguintes condiçōes lineares, com respeito aos al imentos disponiveis:

$$
\begin{aligned}
& a_{11} x_{1}+a_{12} x_{2}+\ldots+a_{1 n} x_{n}(\leqslant,=, \geqslant) b_{1} \\
& a_{21} x_{1}+a_{22} x_{2}+\ldots+a_{2 n} x_{n}(\leqslant,=, \geqslant) b_{2} \\
& a_{m 1} x_{1}+a_{m 2} x_{2}+\ldots+a_{m n} x_{n}\left(\leqslant,=, \geqslant b_{m}\right.
\end{aligned}
$$

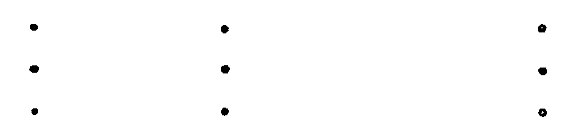

(1) $\sum_{j=1}^{n} a_{i j} x_{j}(\leqslant,=, \geqslant) b_{i}$

$$
\begin{aligned}
& i=1, \ldots, m \\
& j=1, \ldots, n
\end{aligned}
$$

onde:

$x_{j} \geqslant 0$

$a_{i j}=$ proporção do nutriente $i$ no al imento $j$

$b_{i}=$ teor mäximo, mínimo ou fixo do nutriente necessärio

$m=n$ ! de equações de restrição

A representação matricial desse sistema è a seguinte:

$$
\begin{aligned}
& C=\left|\begin{array}{c}
c_{1} \\
c_{2} \\
\vdots \\
c_{n}
\end{array}\right| \quad X=\left|\begin{array}{c}
x_{1} \\
x_{2} \\
\vdots \\
x_{n}
\end{array}\right| \quad A=\left|\begin{array}{cccc}
a_{11} & a_{12} & \ldots & a_{1 n} \\
a_{21} & a_{22} & \ldots & a_{2 n} \\
\vdots & \vdots & & \vdots \\
\vdots & \cdot & & \vdots \\
a_{m 1} & a_{m 2} & \ldots & a_{m n}
\end{array}\right| \quad B=\left|\begin{array}{c}
b_{1} \\
b_{2} \\
\vdots \\
b_{m}
\end{array}\right| \\
& (n \times 1) \quad(n \times 1) \quad(m \times n) \quad(m \times 1)
\end{aligned}
$$


A função objerivo è então expressa pela equação:

$$
z=C^{\prime} x
$$

Sujeita a:

$$
\begin{aligned}
& \text { A. } x \leqslant 0=, \geqslant B \\
& x \geqslant 0
\end{aligned}
$$

Deste modo tem-se um conjunto de inequaçōes lineares cuja solução fornecerà as quantidades dos diferentes alimentos que comporão a dieta de custo minimo.

As inequações poderão ser transformadas em equações através de um conjunto de variảveis auxiliares denominadas variäveis residuais.

Voltando a forma condensada e supondo-se que a expressão (1) apareça sob a forma:

$$
\sum_{j=1}^{n} a_{i j} x_{j} \geqslant b_{i} \quad i=1,2, \ldots, m
$$

Introduzindo-se então as variāveis residuais, positivas, obtem-se:

$$
\sum_{j=1}^{n} a_{i j} x_{j}-x_{n+1}=b_{i} \quad i=1,2, \ldots, m
$$

Podem ser introduzidas nesse conjunto, al ëm das restrições nutricionais, outras que visem a obtenção de dietas palatāveis e que observem os häbitos al imentares da população.

0 método Simplex è o algoritmo mais utilizado para a solução de problemas desse tipo. 
46.

\section{RESULTADOS E DISCUSSÃO}

Neste capitulo são apresentados e discutidos os resultados sobre a adequação nutricional da al imentação adquirida pela população e das dietas de custo minimo obtidas com suas respectivas análises de pósot imização.

Alēm disso sāo analisados os indices de eficiência dos dis pêndios em alimentos efetuados pela população da cidade de São Paulo.

4.1. Adequação nutricional da al imentação adquirida

Inicialmente deve-se mencionar algumas limitaçōes dos resultados devidas, entre outras razões, às seguintes:

a) a aplicação do método "recordatōrio", apesar de facilitar o levantamento, pode apresentar imperfeiçōes em virtude da provävel falta de exatidão das informações fornecidas pelos entrevistados acerca dos alimentos e respectivas quantidades adquiridas no mes em questão; 
b) ○ fato da população ter sido estratificada seṇundo a renda familiar e não a renda familiar "per capita" provavelmente serviu para diminuir as diferenças de renda e, consequentemente, de qualidade de al imentação entre as diferentes classes, pois este tipo de estratificação faz com que as familias maiores, em virtude de terem maior número de pessoas para trabalhar se situem em classes de renda superiores. Portanto, pode ocorrer que familias em estratos de renda superiores apresentem um gasto em alimentos "per capita" menor do que as familias situadas em clas ses inferiores;

c) a maior limitação ocorreu em virtude de não se dispor da informação de compra de alimentos por familia individual e sim a soma dos alimentos adquiridos pelas familias nas värias classes de renda. Assim, para estudar a adequação nutricional da al imentação adquirida pelas classes de renda tem-se que pressupor que haja uma distribuição adequada de alimentos entre e intra familiar. Sabe-se que na realidade è possivel que em uma familia com ingestão nutricional adequada exista algum membro mal alimentado ou, ao conträrio, em uma familia com ingestão inadequada, um ou mais elementos possam estar bem alimentados. Da mesma forma uma classe de renda pode apresentar consumo al imentar suficiente, e grande parte das familias não se alimentar corretamente;

d) como não foi efetuado nenhum exame clínico da população amostrada não se pode considerar as necessidades adicionais de nutrientes que se fariam necessárias caso fosse comprovada a existência de doenças carenciais nessa população; 
e) como a POF estava interessada apenas nas despesas realmente efetuadas no mes anterior pelas familias entrevistadas, não foram levantadas informaçōes sobre os estoques existentes na residência e/ou estoques formados com a compra realizada no período. Para se calcular a adequação da alimentação adquirida, tem-se que pressupor que não tenha havido variação nos estoques alimentares domiciliares nem desperdicios dos al imentos adquiridos:

f) não foram coletados dados sobre a presença de höspedes. em nenhum domicilio no período em estudo;

g) a alimentação feita fora do domicilio não foi incluída no cálculo das disponibilidades de nutrientes em virtude de dispor-se de informações apenas do gasto efetuado e não do tipo de alimentação feita.

Na anālise da adequação nutricional da alimentação adquirida deve-se ter consciência que o nivel de adequação allimentar, apesar de ser um dado muito útil, não justifica por si só a afirmação de que uma determinada população sofre de subnutrição ou mã nutrição. Estas conclusões devem sempre ser apoiadas por exames clínicos ou bioquímicos.

Entretanto, ingestões multo aquēm das recomendações sugerem que esses problemas devem estar presentes.

Sabe-se também, que caso fosse analisada a ingestão nutricional por famillia,provavelmente a situação seria ainda pior do que a que se apresenta quando consideraram-se as familias agrupadas por classe de renda, pois não se tem nenhuma garantia de que os alimentos se distribuam 
49.

homogeneamente entre as familias de uma dada classe de renda.

A necessidade e disponibilidade mensais de nutrientes por famil ia mëdia são apresentadas nas Tabelas 6 e 7 respectivamente.

A divisão dos dados da Tabela 7 pelos equivalentes da Tabela 6 fornece os intervalos de adequação nutricional que são apresentadas na Tabela 8. !/

Ficou evidente neste estudo a relação direta existente entre a renda e disponibilidade de alimentos, sendo que a partir da classe de renda 7 os nutrientes fornecidos pela alimentação alcançaram as recomendações dietárias chegando inclusive a ultrapassä-las nos estratos superiores de renda.

Entretanto, nas primeiras classes, que constituem mais de $70 \%$ da população, as deficiências são grandes. Estas classes apresentam disponibilidade inadequada para os seguintes nutrientes: Ferro, retinol, tiamina, e riboflavina, sendo que destes a situação do reti nol è a mais precária, chegando para a classe 1 a não atingir $30 \%$ das necessidades. $\underline{2}$ primeiro sintoma da deficiência dessa vitamina é a cegueira noturna, seguida pela xerose conjuntiva.

I/ O leitor poderá verificar que para alguns dados, a divisão da Tabela 7 pela 6 resulta em valor ligeiramente diferente do encontrado na Tabela 8. Isto pode ocorrer pois na elaboração desta, trabalhou-se com um nümero maior de decimais do que as que foram apresentadas nas Tabelas 6 e 7 .

2/ Estudos realizados na região por SOBOLL (1973) e CAMPINO e ALVES(1974) apoiam as conclusões relativas ao baixo indice de adequação do retinol. 


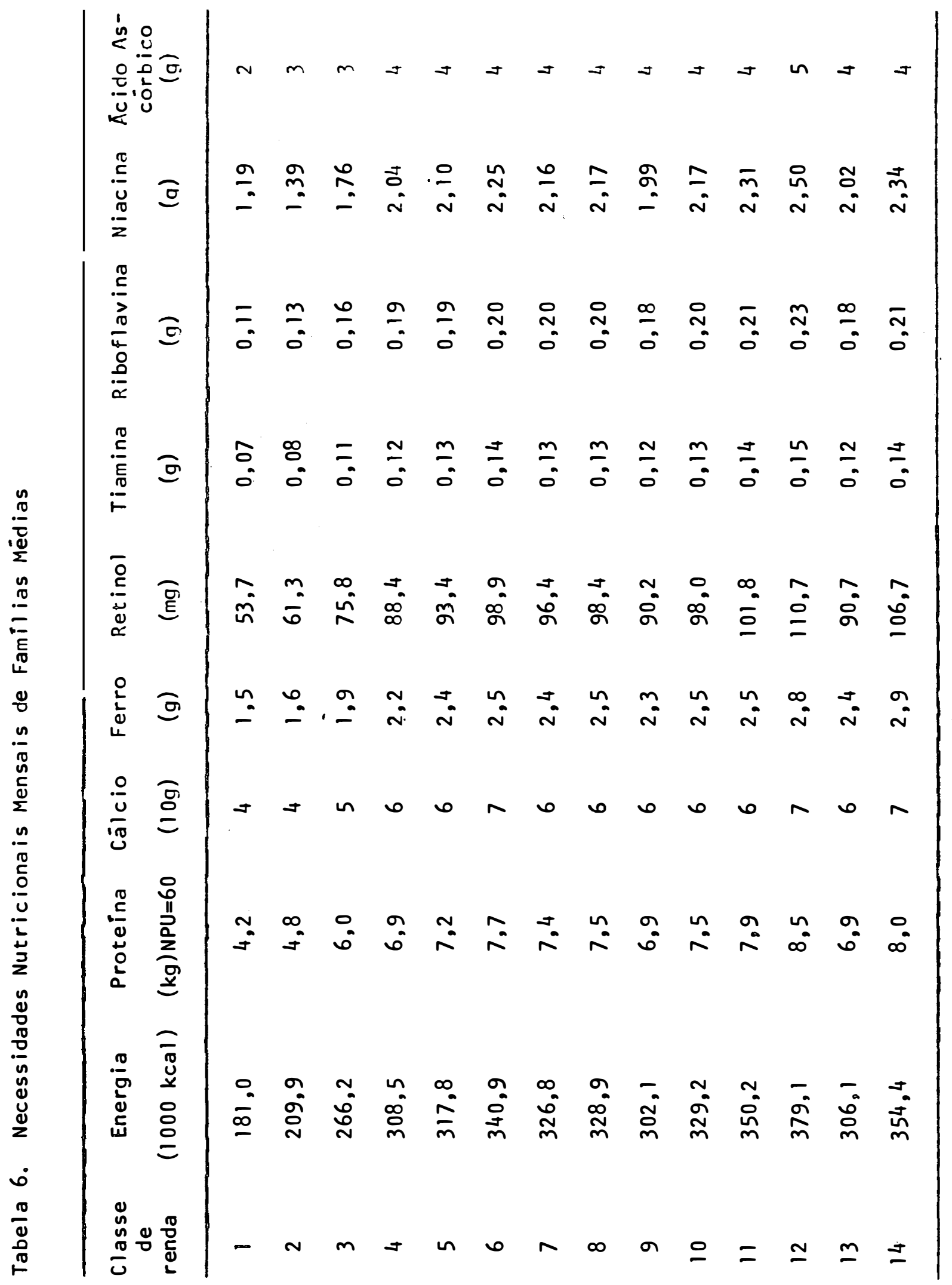




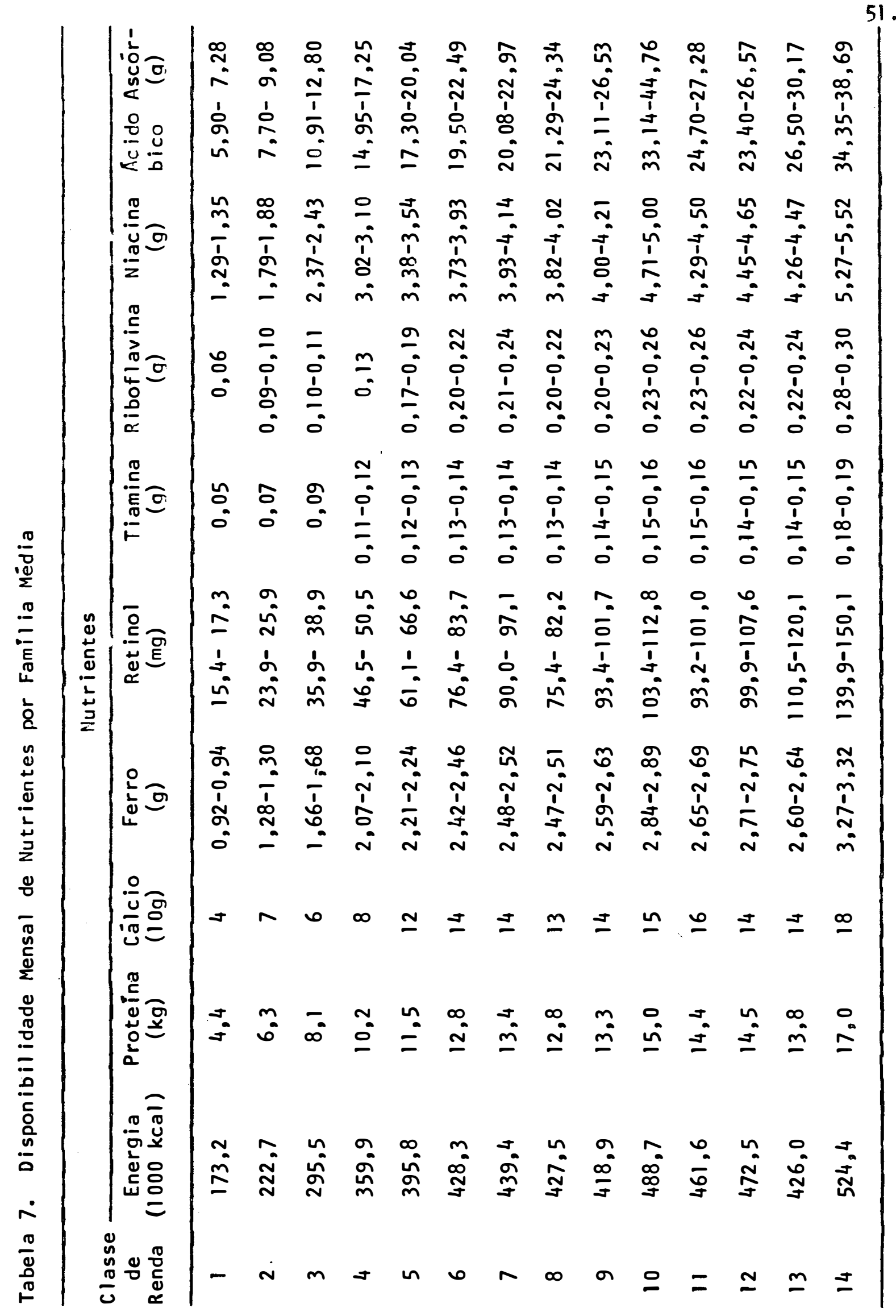




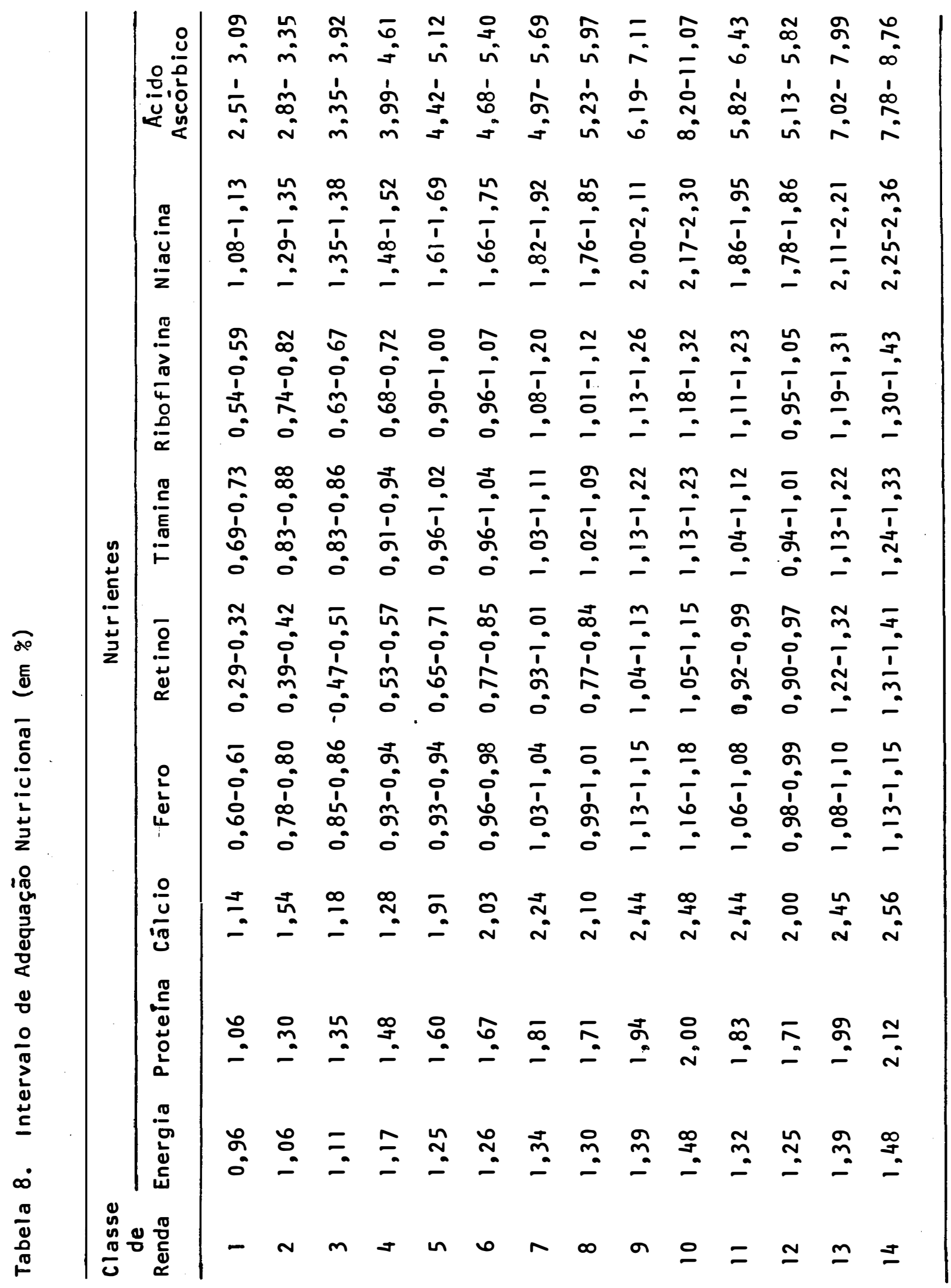


Pode atingị tambèm a cörnea, produzindo a querotomaläcia, que caso não seja tratada pode perfurar ocasionando cegueira permanente no individuo $\underline{3}$.

Outras consequências da ingestão deficiente desse nutriente são: retardamento do crescimento das crianças e jovens, inflamação da mucosa bucal, mã formação dos dentes e gengivas, secura geral com enruga mento e descoloração da pele.

As deficiências de ferro, apesar de não serem tão drästicas estiveram presentes nas seis primeiras classes de renda.

Entretanto, a diferença entre as classes de menores e maio res rendas com relação aos indices de adequação estã subestimada nestes resultados. Isto porque, como a quantidade de ferro estipulada pelas recomendaçōes depende da porcentagem da caloria da dieta que è de origem animal, 4/ optou-se aprioristicamente, independente da classe de renda, pe las recomendações que consideravam que menos $10 \%$ das calorias totais eram de origem animal. Pela Tabela 9 nota-se que a medida que cresce a renda cresce o teor de calorias animais o que indica que as recomendações nas classes de renda mais altas estão mais superestimadas do que as utilizadas para as classes de menor poder aquisitivo.

3/ Os informes FAO: 28/WHO: 61 mencionam estimativas segundo as quais 20 milhöes de crianças se tornam cegas anualmente pela queratomalácia.

4/ Segundo os informes FAO: 28/WHO: 61 na alimentação de origem animal a absorção do ferro se faz de acordo com as seguintes porcentagens: carne: 30\%; peixes: 15\%. Nos al imentos vegetais (com excessão da soja cujo teor de absorção é 20\%) apenas $10 \%$ do ferro é absorvido. 
Tabela 9. Porcentagem de Caloria Alimentar de Origem Animal e Vegetal

\begin{tabular}{|c|c|c|}
\hline \multirow{2}{*}{$\begin{array}{c}\text { Classe de } \\
\text { Renda }\end{array}$} & \multicolumn{2}{|c|}{ Porcentagem da caloria de acordo com a origem } \\
\hline & Animal & Vegetal \\
\hline 1 & 0,17 & 0,83 \\
\hline 2 & 0,17 & 0,83 \\
\hline 3 & 0,15 & 0,85 \\
\hline 4 & 0,16 & 0,84 \\
\hline 5 & 0,20 & 0,80 \\
\hline 6 & 0,21 & 0,79 \\
\hline 7 & 0,24 & 0,76 \\
\hline 8 & 0,23 & 0,77 \\
\hline 9 & 0,23 & 0,77 \\
\hline 10 & 0,25 & 0,75 \\
\hline 11 & 0,25 & 0,75 \\
\hline 12 & 0,24 & 0,76 \\
\hline 13 & 0,26 & 0,74 \\
\hline 14 & 0,26 & 0,74 \\
\hline
\end{tabular}

A insuficiência de ferro causa a anemia hipocrômica, na qual o nümero de cèlulas è reduzido resultando na incapacidade de transportar o oxigênio necessário. A pessoa fica pālida, apresentando entre outros sintomas, fraqueza, tendência para a fadiga, dor de cabeça e palpi tações. 
A tiamina foi outro nutriente cuja disponibilidade não atingiu as recomendaçōes. Sua ingestão deficiente causa o beriberi que po de tomar as seguintes formas: beriberi seco, que è a doença crônica na qual a neurite leva à paralisia dos membros; o beriberi úmido, que è a forma aguda da doença e causa retenção de àgua e distúrbios no sistema circulatörio, que podem levar a morte sübita por parada cardíaca. Ambos os tipos ocasionam perda de apetite, mal estar e fraqueza geral, o que reduzirá drasticamente a capacidade de trabalho. Todavia, esses sintomas podem se estender por anos antes que uma das duas formas se manifeste.

A riboflavina tambēm apresentou disponibilidade inadequada. Sua deficiência, conhecida como arriboflavinose é caracterizada por lesōes bucais, oculares e cutâneas do rosto. Apesar da arriboflavinose não ser considerada tảo prejudicial ao homem quanto as demais deficiências, as dietas que causam o beriberi, pelagra, escorbuto, querotomalàcia ou anemia megaloblastica são igualmente pobres em riboflavina, o que contribui para aumentar o desconforto dos pacientes dessas doenças.

As proteinas, apesar de quantitativamente suficientes, qua litativamente talvez sejam deficitärias, pois apesar de ter sido feita a correção do NPU para 60 que leva em consideração a qualidade da proteína na dieta, de acordo com ESCUDERO (1968) 50\% da proteina alimentar deve ser de origem animal, indice que só foi alcançado a partir da classe de renda 6 , conforme verifica-se na Tabela 10.

Alèm das proteinas de origem animal serem importantes em virtude de conterem aminoācidos essenciais, são indispensāveis na 
manutenção e crescimento normal do organismo. Segundo os informes FAO: 37/WHO: 301 , mais de $90 \%$ dos aminoäcidos das prnteinas animais são absorvidos, enquanto que para as de origem vegetal a absorção pode ser de $80 \%$ ou menos.

Tabela 10. Porcentagem de Proteina Al imentar de Origem Animal e Vegetal

\begin{tabular}{ccc}
\hline $\begin{array}{c}\text { Classe } \\
\text { de } \\
\text { Renda }\end{array}$ & Porcentagem de Proteina Total de Acordo com a Origem \\
\cline { 2 - 3 } & Animal & Vegetal \\
\hline 1 & 0,32 & 0,68 \\
2 & 0,38 & 0,62 \\
3 & 0,37 & 0,63 \\
4 & 0,41 & 0,59 \\
5 & 0,48 & 0,52 \\
6 & 0,50 & 0,50 \\
7 & 0,55 & 0,45 \\
8 & 0,53 & 0,47 \\
9 & 0,54 & 0,46 \\
10 & 0,55 & 0,45 \\
11 & 0,57 & 0,43 \\
12 & 0,55 & 0,45 \\
13 & 0,59 & 0,41 \\
14 & 0,60 & 0,40 \\
\hline & &
\end{tabular}


Dietas deficientes em proteinas ocasionam o kwashiorkor, cujos sintomas principais são o crescimento prejudicado, estado mental de apatia e irritação, edema, vômito, diarrēia, dilatação de fígado e anemia.

\subsection{Dietas de custo minimo}

4.2.1. Indice de eficiência dos gastos em alimentação

Comprovou-se em anälises anteriores, que as familias das seis primeiras classes de renda dispunham de alimentação inadequada para a manutenção da saüde e crescimento, visto que apresentaram em värios nutrientes disponibilidade inferior às recomendaçōes dietärias.

Todavia, poderia acontecer que, apesar de não terem se al i mentado adequadamente, houvessem realizado os dispêndios com certa racionalidade e que os recursos monetärios de que dispunham fossem insuficientes para garantir uma al imentação adequada.

Para testar esta hipótese calcularam-se os indices de eficiência dos gastos em al imentação que mostram o grau no qual os nutrientes adquiridos são obtidos pelo menor custo.

O total dos gastos dispendidos na al imentação por uma dada população pode ser dividido em dois componentes:

- Nutricional, definido como o gasto necessärio para adqui rir a al imentação de custo minimo que fornece o mesmo teor nutricional da que usualmente compra; 
58.

- Não nutricional ou cultural, obtido através da diferença entre o gasto total e o nutricional.

Portanto, para se determinar o gasto nutricional necessita-se inicialmente medir a ingestão de nutrientes de uma dada população e a seguir calcular a dieta de custo minimo que fornece essa ingestão.

Essa al imentação de custo minimo è elaborada sem incluir no modelo restrições sobre a palatabilidade ou os gostos e preferências dos consumidores, visto que a inclusão de limitações dessa natureza implica em acrescentar um componente de teor não nutricional ou cultural.

No presente trabalho, a ünica concessão aos häbitos alimen tares, foi a lista dos alimentos disponiveis ter sido elaborada com base nos alimentos adquiridos na época pela população.

As quantidades de nutrientes das dietas mensais adquiridas pelas famflias médias das seis primeiras classes de renda foram estipuladas baseando-se nas obtidas, considerando-se que os alimentos adquiridos que poderiam ser consumidos crús ou cozidos foram ingeridos na forma crua. Esses valores foram apresentados na Tabela 7. A partir dessas informações obtiveram-se as dietas de custo minimo apresentadas na Tabela 11 , que fornecem esses nutrientes em quantidades iguais ou superiores às contidas nas dietas que eram adotadas pelas familias da amostra.

Verifica-se que, embora as quantidades de nutrientes que deveriam ser fornecidas variassem entre as seis classes, as soluções ötimas obtidas se constituiram basicamente dos mesmos alimentos, com alteraçōes apenas nas quantidades de cada um. 0 conteüdo nutricional dessas 
dietas de custo mínimo è apresentado na Tabela 12.

Como não se estabeleceram restrições quanto às quantidades mäximas ou minimas permitidas para os alimentos, logicamente o "preço sombra" (reduced cost) que mostra de quanto seria reduzido o custo da die ta para cada unidade adicional do alimento, se pudessem ser relaxados os limites impostos as variảveis, foi nulo para todos os alimentos.

Tabela 11. Alimentos e Respectivas Quantidades nas Dietas de Custo Minimo Elaboradas com Base nas Dietas Adquiridas pelas Familias da Amostra

\begin{tabular}{|c|c|c|c|c|c|c|}
\hline \multirow{2}{*}{$\begin{array}{l}\text { Al imento } \\
(100 \mathrm{~g})\end{array}$} & \multicolumn{6}{|c|}{ Classe de Renda } \\
\hline & 1 & 2 & 3 & 4 & 5 & 6 \\
\hline Acelga & 48,75 & $159,62^{\circ}$ & 22,80 & 20,62 & 128,60 & 187,38 \\
\hline Feijão soja & 160,08 & 228,05 & 254,70 & 316,39 & 450,48 & 506,32 \\
\hline Fubá & 288,72 & 341,00 & 500,13 & 593,24 & 552,71 & 573,90 \\
\hline Goiaba & 27,78 & 20,84 & 56,49 & 77,19 & 76,59 & 80,01 \\
\hline Rim & 11,59 & 21,98 & 63,36 & 100,67 & 59,15 & 66,47 \\
\hline Total & 536,92 & 771,49 & 897,48 & 1108,11 & 1267,53 & 1414,08 \\
\hline
\end{tabular}


60.

Tabela 12. Teor de Nutrientes das Dietas de Custo Minimo Elaboradas com Base nas Dietas Adquiridas pelas Familias da Amostra

\begin{tabular}{|c|c|c|c|c|c|c|}
\hline \multirow{2}{*}{ Nutrientes } & \multicolumn{6}{|c|}{ Classe de Renda } \\
\hline & 1 & 2 & 3 & 4 & 5 & 6 \\
\hline $\begin{array}{l}\text { Energia } \\
(1000 \mathrm{kca}))\end{array}$ & 173,2 & 222,7 & 295,5 & 359,9 & 395,8 & 428,3 \\
\hline $\begin{array}{l}\text { Proteina } \\
(\mathrm{kg})\end{array}$ & 7,9 & 10,9 & 13,6 & 17,0 & 20,6 & 22,9 \\
\hline Cálcio(log) & 4 & 7 & 6 & 8 & 12 & 14 \\
\hline Ferro(g) & 2,1 & 3,2 & 3,5 & 4,4 & 5,8 & 6,6 \\
\hline Retinol $(g)$ & 25,6 & 57,1 & 38,9 & 50,5 & 66,6 & 83,7 \\
\hline Tiamina (g) & 0,12 & 0,17 & 0,21 & 0,26 & 0,33 & 0,36 \\
\hline Riboflavina (g) & 0,06 & 0,10 & 0,16 & 0,23 & 0,21 & 0,24 \\
\hline Niacina $(g)$ & 1,35 & 1,88 & 2,43 & 3,10 & 3,54 & 3,93 \\
\hline $\begin{array}{l}\text { Acido } \\
\text { Ascörbico (g) }\end{array}$ & 7 & 9 & 13 & 17 & 20 & 22 \\
\hline
\end{tabular}

As soluções ötimas resultantes, embora no aspecto de estrü tura de almoço e jantar nāo fugissem muito do habitual, apresentaram graves limitaçōes, ou seja:

a) Composição pouco variada, aliada ao aparecimento de quantidades tão el evadas de cada alimento (exceto para o rim e a goiaba), que seu consumo se torna inviävel.

b) Não incluem condimentos, devendo portanto ser ingeridas sem sal, pimenta, öleo e vinagre. 
c) Não estão de acordo com häbitos alimentares da população.

0 indice de eficiência foi calculado separadamente para as familias médias das seis primeiras classes de renda, através do cociente entre o gasto nutricional e total e os resultados obtidos estão na Tabela 13.

Os indices de eficiência encontrados foram muito baixos, sendo que o médio das seis classes de renda foi 0,37 , inferior, portanto, ao 0,59 calculado por SMITH e FLORENCIO (1967) para uma amostra de familias da classe trabalhadora colombiana.

Observa-se tambèm a tendência dos indices crescerem com - decréscimo na renda familiar. Todavia, mesmo a classe de renda mais bai $x a$, que apresentou o melhor indice, efetuou seus dispêndios em alimentação de maneira menos eficiente que a população da Colombia.

Tomando-se as mëdias das classes, ve-se que os nutrientes que foram adquiridos por Cr\$313,79 poderiam ter sido comprados por Cr\$ 114,75 , ou seja, o componente nutricional da alimentação média custou Cr\$114,75 e o cultural ou não nutricional Cr\$199,04. Se as familias gastassem esses Cr\$199,04 adicionais nos alimentos constituintes das die tas de custo minimo poderiam adquirir 1,73 dietas de custo mínimo.

Outro fator importante a se considerar è que embora as familias das seis primeiras classes de renda dispusessem de alimentação ina dequada, para alguns nutrientes a disponibilidade foi maior do que as 
62.

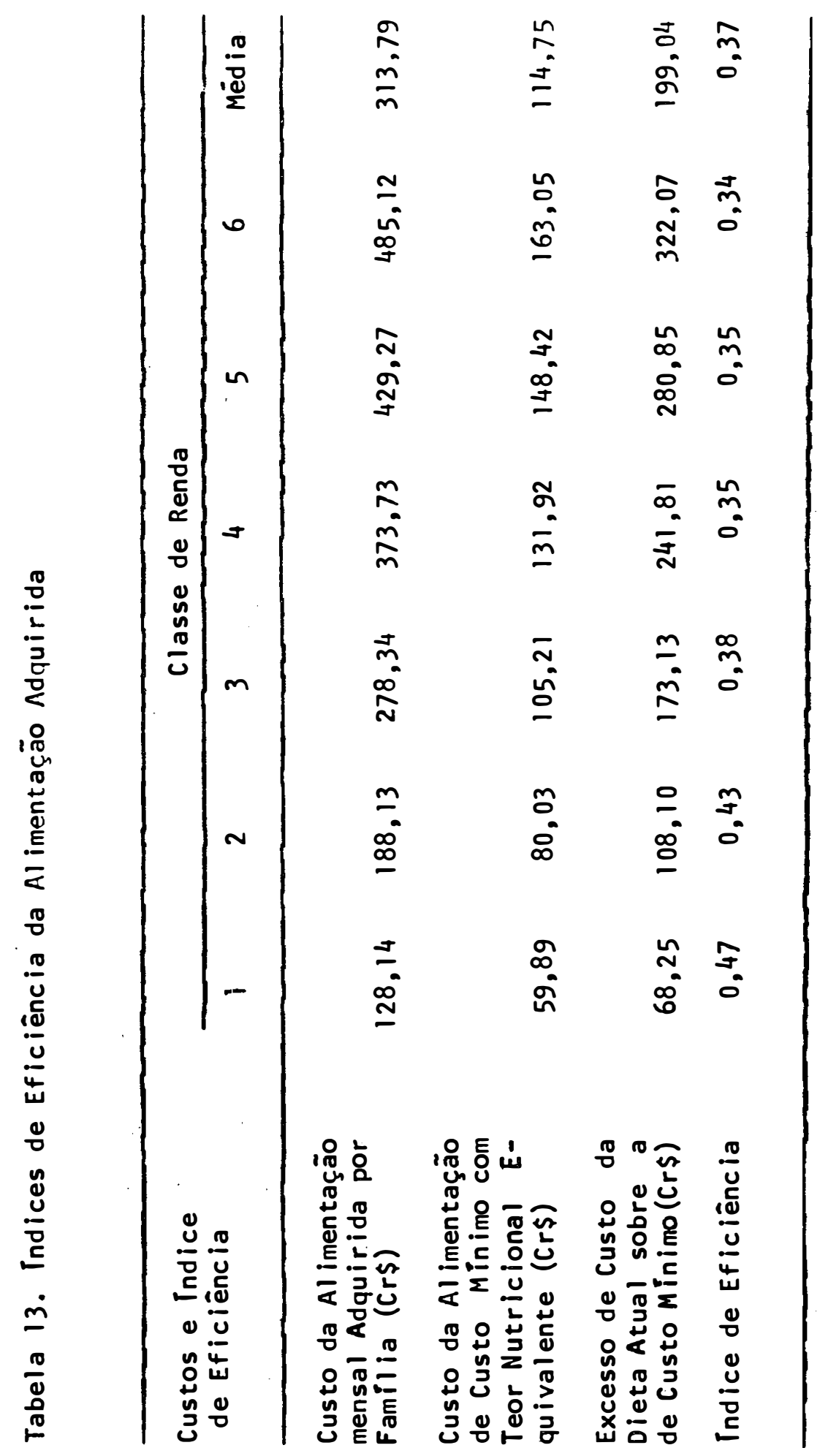


recomendações, como se pode comprovar atravēs da comparação das tabelas 6 e 7. Isto indica que a melhoria da situação nutricional pode ocorrer de duas maneiras: atravès da compra mais eficiente de alimentos no sentido de proporcionar um dado conjunto de nutrientes e através da melhor seleção do montante nutricional a ser fornecido pela alimentação.

As dietas de custo minimo elaboradas com o objetivo de satisfazer as necessidades de nutrientes da população propiciam a melhoria da situação nutricional atravēs das duas maneiras citadas.

4.2.2. Dietas obtidas com o modelo simples

4.2.2.1. Alimentos e teor nutricional das dietas

Neste modelo levaram-se em consideração apenas as restrições relativas às necessidades nutricionais mensais das famillias médias representativas das seis primeiras classes.

A ünica concessão aos häbitos alimentares foi novamente a lista dos alimentos disponiveis à escolha ser baseada nos alimentos adqui ridos na época pela população.

As soluçōes ótimas encontradas estão apresentadas na Tabela 14.

Novamente ocorreu que, embora as necessidades nutricionais fossem diferentes para as familias mëdias das värias classes, os alimentos constituintes das dietas foram os mesmos, alterando-se apenas as quan tidades nas quais deveriam ser ingeridos. 
Tabela 14. Al imentos e Respectivas Quantidades nas Dietas de Custo Mini mo Elaboradas Através do Modelo Simples

\begin{tabular}{lrrrrrr}
\hline $\begin{array}{c}\text { Al imentos } \\
(100 \mathrm{~g})\end{array}$ & \multicolumn{1}{c}{ Classe de Renda } \\
\cline { 2 - 7 } & 1 & \multicolumn{1}{c}{2} & 3 & \multicolumn{1}{c}{4} & \multicolumn{1}{c}{5} & \multicolumn{1}{c}{6} \\
\hline Acelga & 193,19 & 163,72 & 157,24 & 173,43 & 205,47 & 208,58 \\
Feijão soja & 32,62 & 42,56 & 57,80 & 67,63 & 67,53 & 73,39 \\
Fubä & 422,23 & 481,47 & 606,89 & 703,20 & 729,82 & 780,43 \\
Leite em pó & 9,82 & 17,44 & 23,94 & 27,48 & 24,03 & 27,68 \\
Rim & 41,39 & 44,63 & 57,02 & 66,73 & 71,85 & 75,68 \\
\hline Total & 699,25 & 749,82 & 902,89 & 1038,47 & 1098,7 & 1165,76 \\
\hline
\end{tabular}

0 "preço Sombra" foi zero para todos os al imentos, pois não foram estipulados limites mäximos ou mínimos para as quantidades de alimentos, visto que este modelo tinha por objetivo apenas 0 atendimento às necessidades de nutrientes da população.

A Tabela 15 mostra o teor nutricional das dietas obtidas atravès do modelo simples.

A energia, o cälcio, ferro, riboflavina e niacina apareceram em quase todas as soluções ótimas em seus limites inferiores, o que indica que caso estes pudessem ser relaxados as dietas apresentariam custo ainda menor. 
Tabela 15. Teor de Nutrientes das Dietas de Custo Minimo Elaboradas Atra vès do Modelo Simples

\begin{tabular}{|c|c|c|c|c|c|c|}
\hline \multirow{2}{*}{ Nutrientes } & \multicolumn{6}{|c|}{ Classe de Renda } \\
\hline & 1 & 2 & 3 & 4 & 5 & 6 \\
\hline $\begin{array}{l}\text { Energia } \\
(1000 \mathrm{Kcal})\end{array}$ & 181,0 & 209,9 & 266,2 & 308,5 & 317,8 & 340,9 \\
\hline Proteína (g) & 5,6 & 6,7 & 8,5 & 9,9 & 10,1 & 10,9 \\
\hline Cälcio $(10 \mathrm{~g})$ & 4 & 4 & 5 & 6 & 6 & 7 \\
\hline Ferro $(g)$ & 1,5 & 1,6 & 1,9 & 2,2 & 2,4 & 2,5 \\
\hline Retinol (mg) & 74,1 & 71,1 & 78,0 & $88,4^{\circ}$ & 97.7 & 101,8 \\
\hline Tiamina ( $g$ ) & 0,07 & 0,09 & 0,11 & 0,13 & 0,13 & 0,14 \\
\hline Riboflavina (g) & 0,11 & 0,13 & 0,16 & 0,19 & 0,19 & 0,20 \\
\hline Niacina $(g)$ & 1,19 & 1,39 & 1,76 & 2,04 & 2,10 & 2,25 \\
\hline $\begin{array}{l}\text { Acido } \\
\text { Ascörbico (g) }\end{array}$ & 6 & 5 & 5 & 5 & 6 & 7 \\
\hline
\end{tabular}

Supos-se inicialmente que a proteina fosse 0 nutriente mais caro, mas tal não ocorreu pois as dietas fornecen cerca de $40 \%$ a mais do que suas quantidades recomendadas.

4.2.2.2. Anảlise pós-otimização das dietas obtidas atravēs do Modelo Simples

As informações contidas na anālise de pōs-otimização estão apresentadas no Apêndice 3. As três primeiras colunas referem-se aos 
alimentos selecionados, seus preços unitärios e às quantidades obtidas na solução ótima. As demais colunas mostram os preços mäximos e mínimos per mitidos para a variävel sem que se altere a solução ötima. Números negativos na coluna "quantidade do alimento na dieta se o custo atingir o mäximo" significam que se os preços atingirem os niveis indicados, 0 alimento serä el iminado da dieta. Obtem-se informaçōes sobre a estabilidade de um alimento na solução ótima atravēs da comparação entre as variaçōes percentuais nos preços com relação aos preços atuais do produto e as variaçōes percentuais respectivas na sua quantidade.

No apêndice 3, a tabela 29 mostra, por exemplo, que se 0 preço do leite em pó aumentar de Cr\$ 0,370 para Cr\$ 0,394 , sua quantidade na dieta cairá de $982,0 \mathrm{~g}$ para $426,7 \mathrm{~g}$. Por outro lado, se o preço baixar para Cr\$ 0,195 a quantidade aumentarä para 4723,8 g:

Essas informações demonstram a instabilidade desse produto na dieta face à variação de preços, pois um acréscimo de $6,49 \%$ em seu preço ocasionarã a diminuição de $56,55 \%$ em sua quantidade na solução. Por outro lado, uma queda de $47,30 \%$ no seu preço ocasionará o aumento de $381,04 \%$ em sua quantidade.

Esta anälise pode ser estendida aos demais alimentos, sendo que de uma maneira geral, o alimento mais estāvel em relação a alteraçōes nos preços nas dietas resultantes do modelo simples, para todas as classes de renda, foi o fubä e o mais instävel o leite em pó.

A acelga apresentou-se relativamente estävel face a elevaçōes nos preços mas muito sensivel a quedas de preços, o que demonstra a 
tendência do produto ou de permanecer na dieta em quantidade relativamente imutável caso o seu preço se eleve de atē $13,33 \%$ ou de ter a quantidade acrescida em grande escala caso ele baixe de cerca de $10 \%$.

Das dietas encontradas, a elaborada para a classe 6 foi 1 i geiramente mais estāvel, mas, de uma maneira geral, em cada classe alguns al imentos se mostraram menos sensiveis a variações de preços e outros mais sensiveis, o que impossibilita a classificação das dietas por sua es tabilidade face à variações nos preços dos al imentos que a compōem.

\subsubsection{Custo das Dietas e Renda Familiar}

A Tabela 16 apresenta uma comparação entre os custos das dietas adquiridas pelas familias da amostra e das dietas de custo mínimo

Tabela 16. Custo da Al ịmentação Adquirida pelas Familias da Amostra e da Dieta de Custo Minimo Elaborada Atravēs do Modelo Simples

\begin{tabular}{lcccccccc}
\hline $\begin{array}{l}\text { Custos } \\
\text { (Cr\$) }\end{array}$ & 1 & 2 & 3 & 4 & 5 & 6 & Média \\
\cline { 2 - 8 } & 128,14 & 188,13 & 278,34 & 373,73 & 429,27 & 485,12 & 313,79 \\
\hline $\begin{array}{l}\text { Dietas } \\
\text { Adquiridas }\end{array}$ & $\begin{array}{l}\text { Classe de Renda } \\
\begin{array}{l}\text { Dietas de } \\
\text { Custo Minimo }\end{array}\end{array}$ & 58,77 & 68,18 & 86,01 & 99,50 & 102,28 & 109,81 & 87,43 \\
$\begin{array}{l}\text { Excesso de Custo } \\
\text { da Dieta Adquiri } \\
\text { da sobre a de } \\
\begin{array}{l}\text { Custo Minimo } \\
\hline\end{array}\end{array}$ & 69,37 & 119,95 & 192,33 & 274,23 & 326,99 & 375,31 & 226,36 \\
\hline
\end{tabular}


Verifica-se que as familias obteriam reduçōes significativas nos seus dispêndios em al imentação, aliadas ao atendimento das neces sidades nutricionais, se adotassem as dietas de custo minimo. Se, por exemplo, as familias da classe de renda 1 gastassem o componente não nutricional de sua al imentação (cr\$69,37) com 100\% de eficiência poderiam adquirir 1,18 (ou Cr $\$ 69,37 / \operatorname{Cr} \$ 58,77$ ) dietas de custo minimo. Caso elas utilizassem os Cr\$128,14 que è o custo de sua al imentação com $100 \%$ de eficiência poderiam adquirir 2,18 (ou cr $\$ 128,14 / \operatorname{cr} \$ 58,77$ ) unidades da die ta de custo minimo. Dessas 2,18 unidades, 54,14\% $\left(\frac{\operatorname{cr} \$ 69,37 / \operatorname{cr} \$ 58,77}{\operatorname{cr} \$ 128,14 / \operatorname{cr} \$ 58,77}\right)$ viriam da melhoria da eficiência dos gastos por usar o componente não nutricional para a compra da al imentação de custo mínimo. 0s $45,86 \%$ restantes seriam obtidos por utilizar os nutrientes no nivel das recomendaçōes ao invès das quantidades usualmente consumidas.

Independentemente da percentagem de redução de custos ser obtida atravēs da melhor seleção de nutrientes ou de alimentos, a economia resultante è considerävel e mesmo as familias de menor poder aquisiti vo poderiam obter al imentação adequada.

Como se verifica na Tabela 17 mesmo as famillias do estrato 1, que tem menor poder aquisitivo precisariam dispender um valor razoavel, ou seja, 32,33\% de sua renda para obter uma al imentação adequada.

Entretanto, essas soluções ótimas obtidas apresentaram as mesmas limitações das dietas preparadas para o cālculo do indice de eficiência, ou seja, composição pouco variada e não inclusão de condimentos, alèm da não observância de häbitos al imentares da população. 
Tabela 17. Percentagens das Rendas Necessärias para a Aquisição das Dietas de Custo Minimo Elaboradas Atravēs do Modelo Simples

\begin{tabular}{lcccccc}
\hline & \multicolumn{5}{c}{ Classe de Renda } \\
\cline { 2 - 7 } & 1 & 2 & 3 & 4 & 5 & 6 \\
\hline $\begin{array}{l}\text { Renda Familiar } \\
\text { Mensal Mëdia } \\
(\text { Cr\$) }\end{array}$ & 181,76 & 359,76 & 686,72 & 1116,58 & 1569,05 & 2012,36 \\
$\begin{array}{l}\text { Custo da Ali- } \\
\text { mentação Men- } \\
\text { Sal de Custo } \\
\text { Minimo (Cr\$) }\end{array}$ & 58,77 & 68,18 & 86,01 & 99,50 & 102,28 & 109,81 \\
$\begin{array}{l}\% \text { da Renda a } \\
\text { Ser Gasta em }\end{array}$ & 32,33 & 18,95 & 12,52 & 8,91 & 6,52 & 5,46 \\
Al imentos & & & & & & \\
\hline
\end{tabular}

Esses resultados, que são coerentes com os obtidos em trabalhos anteriores!', sugerem que quando não se inclui no modelo de programação linear restrições que visem a obtenção de dietas palatāieis e a observância dos gostos e preferências dos consumidores, este modelo tem pouca aplicabilidade na solução de problemas de al imentação humana.

Assim, para tentar eliminar essas limitações, foi construí do um segundo modelo ao qual convencionou-se denominar "modelo palatável".

I/ Ver a esse respeito o "modelo anão" de SMITH (1964), a dieta 1 de OMETTO et alii (1974) e a dieta de STIGLER (1945). 


\subsubsection{Dietas obtidas com o modelo palatävel}

\subsubsection{Alimentos e teor nutricional das dietas}

Neste modelo, além de serem consideradas as necessidades nutricionais mensais das familias mëdias procurou-se ainda conseguir um conjunto de al imentos que, através de sua distribuição nos värios dias do mes, possibilitasse a obtenção de cardápios estruturados de acordo com hä bitos al Imentares da população amostrada, palatāveis, com variedade razoävel e adequadamente condimentados.

No tocante à estrutura das refeições considerou-se que 0 desjejum è constituído de café, leite, pão e manteiga e que o almoço e jantar compreendem usualmente os seguintes alimentos: arroz, feijão, legumes e hortaliças, carne ou similar e frutas.

Agruparam-se as quantidades adquiridas de legumes e hortaliças por classe de renda e o total assim obtido foi dividido pelo número de familias que a compunham, obtendo-se assim a disponibilidade de consumo por familia mëdia de cada classe.

Procedeu-se da mesma maneira para se obter a disponibilida de de consumo médio das frutas e das carnes ou similares.

Estabeleceu-se como limites minimos metade da disponibilidade média dos seguintes allmentos ou grupos de alimentos: arroz, feijão, legumes, carnes ou similares, frutas, öleo, café, leite, pão, manteiga e açücar. 
Esses limites isoladamente irlam favorecer 0 aparecimento de dietas estruturadas adequadamente. Todavia não implicariam em refeiçōes suficientemente variadas.

Para conseguir essa variedade fixou-se como limites mäximos para todos os alimentos o montante igual a duas ou três vezes a disponibilidade média, ou seja, duas vezes no caso dele ser consumido muito frequentemente como o arroz e o feijão e três vezes para o caso de ser menor a frequência, incluindo aqui os grupos dos legumes, das carnes ou similares, das frutas e os alimentos individuais que participaram ou não desses grupos. Para o óleo e o açücar o limite superior fol 1,5 a disponibilidade média.

Para obter refeições adequadamente condimentadas estipularam-se valores fixos iguais às mëdias de compra para os seguintes alimentos: sal, pimenta, alho, cebola, vinagre e salsa/cebolinha.

Esses limites. foram estabelecidos de forma arbiträria. Entretanto, não se podería proceder de maneira diferente visto a não disponibilidade de informaçōes diretas dos consumidores sobre o intervalo de variação das quantidades de alimentos que estariam dispostos a ingerir.

Saliente-se também que os resultados são extremamente sensiveis à esses coeficientes.

Os alimentos $e$ as respectivas quantidades e atividades duais que compōem as dietas obtidas através desse modelo são apresentados nas Tabelas 18 a 23. 
Tabela 18. Al imentos, Respectivas Quantidades e Atividade Dual das Dietas Obtidas Através do Modelo Palatável para a Familia Média da Classe de Renda 1

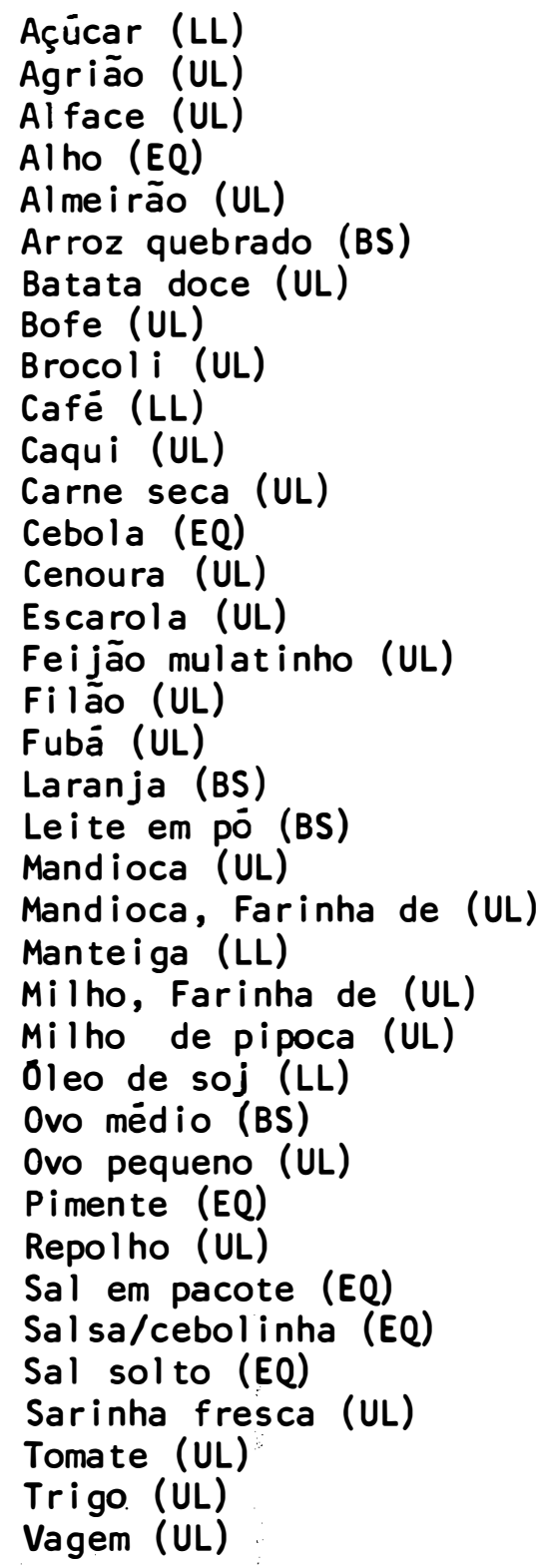$$
\begin{array}{r}
-0,08856 \\
0,42215 \\
0,01409 \\
-0,86647 \\
0,30068 \\
-0,04012 \\
0,2372 \\
0,55021 \\
0,09055 \\
-0,20816 \\
0,21537 \\
0,20307 \\
-0,05339 \\
1,22766 \\
0,19068 \\
0,60142 \\
0,05597 \\
0,06790 \\
0
\end{array}
$$$$
0,00509
$$$$
0,49792
$$$$
-0,17984
$$$$
0,03444
$$$$
0,10980
$$$$
-0,27000
$$$$
0
$$$$
0,04000
$$$$
2,75394
$$$$
0,04395
$$$$
-0,04856
$$$$
0,18002
$$$$
-0,04856
$$$$
0,23857
$$$$
0,03743
$$$$
0,18960
$$

0,01500 
Tabela 19. Alimentos, Respectivas Quantidades e Atividade Dual das Dietas Obtidas Através do Modelo Palatável para a Familia Média da Classe de Renda 2

\begin{tabular}{|c|c|c|}
\hline Al imento & Quantidade & Atividade Dual \\
\hline $\begin{array}{l}\text { Aböbora (UL) } \\
\text { Acelga (UL) } \\
\text { Açúcar (LL) } \\
\text { Agrião (UL) } \\
\text { Alho (EQ) } \\
\text { Almeirão (UL) } \\
\text { Arroz quebrado (LL) } \\
\text { Banana nanica (BS) } \\
\text { Batata doce (UL) } \\
\text { Brocoli (UL) } \\
\text { Café (LL) } \\
\text { Cebola (EQ) } \\
\text { Cenoura (UL) } \\
\text { Escarola (UL) } \\
\text { Espinafre (UL) } \\
\text { Feijão mulatinho (UL) } \\
\text { Feijão soja (UL) } \\
\text { Figado de boi (UL) } \\
\text { Filão (BS) } \\
\text { Fubä (UL) } \\
\text { Leite em pó (BS) } \\
\text { Mandioca, Farinha de (UL) } \\
\text { Manga (UL) } \\
\text { Manteiga (LL) } \\
\text { Milho, Farinha de (UL) } \\
\text { Milho de pipoca (UL) } \\
\text { Miolo de boi (UL) } \\
\text { Nabo (UL) } \\
\text { Oleo de soja (LL) } \\
\text { Ovo médio (BS) } \\
\text { Ovo pequeno (UL) } \\
\text { Pimenta (EQ) } \\
\text { Repolho (UL) } \\
\text { Requeijão (UL) } \\
\text { Sal em pacote (EQ) } \\
\text { Salsa/cebolina (EQ) } \\
\text { Sal solto (EQ) } \\
\text { Sardinha fresca (UL) } \\
\text { Tomate (BS) } \\
\text { Trigo (UL) } \\
\text { Vinagre (EQ) }\end{array}$ & $\begin{array}{r}1,9300 \\
1,49600 \\
40,31600 \\
3,38000 \\
1,77700 \\
5,63300 \\
59,91200 \\
104,29700 \\
3,31300 \\
1,21600 \\
8,13700 \\
12,38400 \\
9,18400 \\
5,58700 \\
1,21600 \\
115,45300 \\
3,13900 \\
1,79400 \\
103,92429 \\
7,68800 \\
95,98580 \\
33,18300 \\
5,36900 \\
1,67200 \\
3,86300 \\
0,85600 \\
1,15800 \\
1,49600 \\
15,97100 \\
21,90800 \\
8,08900 \\
0,21000 \\
68,21100 \\
2,22600 \\
11,71600 \\
0,86600 \\
0,46600 \\
9,59300 \\
101,98664 \\
0,24400 \\
4,49500\end{array}$ & $\begin{array}{c}0,08742 \\
0,45874 \\
-0,03862 \\
0,28476 \\
-0,91344 \\
0,20532 \\
-0,05166 \\
0 \\
0,19013 \\
0,03060 \\
-0,33956 \\
-0,09918 \\
1,07652 \\
0,09532 \\
0,31522 \\
0,27452 \\
0,46829 \\
7,82526 \\
0 \\
0,06197 \\
0 \\
0,23864 \\
0,09716 \\
-0,16576 \\
0,02642 \\
0,03867 \\
0,22659 \\
0,01129 \\
0 \\
0 \\
0,04000 \\
2,05637 \\
0,01495 \\
0,66467 \\
-0,05422 \\
0,05833 \\
-0,05422 \\
0,28984 \\
0 \\
0,05806 \\
-0,06934\end{array}$ \\
\hline
\end{tabular}


Tabela 20. Alimentos, Respectivas Quantidades e Atividade Dual das Dietas Obtidas Através do Modelo Palatāvel para a Familia Média da Classe de Renda 3

\begin{tabular}{|c|c|c|}
\hline Al imento & Quantidade & Atividade Dual \\
\hline $\begin{array}{l}\text { Acelga (UL) } \\
\text { Açúcar (LL) } \\
\text { Agrião (BS) } \\
\text { Alho (EQ) } \\
\text { Almeirão (UL) } \\
\text { Arroz quebrado (LL) } \\
\text { Banana nanica (BS) } \\
\text { Batata doce (UL) } \\
\text { Bofe (UL) } \\
\text { Cafē (LL) } \\
\text { Caqui (UL) } \\
\text { Cebola (EQ) } \\
\text { Cenoura (UL) } \\
\text { Espinafre (UL) } \\
\text { Feijão mulatinho (UL) } \\
\text { Feijão de soja (UL) } \\
\text { Figado de boi (UL) } \\
\text { Filão (BS) } \\
\text { Fubá (UL) } \\
\text { Leite em pó (BS) } \\
\text { Mandioca, Farinha de (UL) } \\
\text { Manga (UL) } \\
\text { Margarina (LL) } \\
\text { Milho, Farinha de (UL) } \\
\text { Milho de pi poca (UL) } \\
\text { Miolo de boi (UL) } \\
\text { Moranga (UL) } \\
\text { Mostarda (UL) } \\
\text { Oleo de soja (LL) } \\
\text { Ovo médio (BS) } \\
\text { Ovo pequeno (UL) } \\
\text { Pimenta (UL) } \\
\text { Repolho (UL) } \\
\text { Sal em pacote } \\
\text { Salsa/cebolinha } \\
\text { Sal solto } \\
\text { Sardinha fresca (UL) } \\
\text { Toucinho fresco (BS) } \\
\text { Trigo (UL) } \\
\text { Vinagre (EQ) }\end{array}$ & $\begin{array}{r}9,88300 \\
47,40400 \\
1,94284 \\
2,42300 \\
9,87800 \\
80,94300 \\
139,59300 \\
4,15700 \\
0,07100 \\
9,70900 \\
5,67500 \\
17,90500 \\
23,02900 \\
6,50300 \\
132,56500 \\
1,26800 \\
3,59600 \\
221,12708 \\
12,92900 \\
60,15957 \\
23,39000 \\
9,65700 \\
2,75900 \\
3,50900 \\
2,18000 \\
0,43200 \\
0,75600 \\
2,23100 \\
25,01700 \\
33,29533 \\
10,99600 \\
0,22800 \\
88,77600 \\
14,48400 \\
2,00300 \\
0,29200 \\
13,92600 \\
8,79667 \\
0,33400 \\
6,21900\end{array}$ & $\begin{array}{c}0,21540 \\
-0,00262 \\
0 \\
-0,92052 \\
0,03544 \\
-0,03670 \\
0 \\
0,04593 \\
0,27002 \\
-0,37185 \\
0,03525 \\
-0,11268 \\
0,34695 \\
0,10411 \\
0,18417 \\
0,32121 \\
3,01304 \\
0 \\
0,05485 \\
0 \\
0,16650 \\
0,00534 \\
-0,50762 \\
0,00666 \\
0,03743 \\
0,15632 \\
0,09536 \\
0,09309 \\
-0,05445 \\
0 \\
0,04000 \\
-0,02754 \\
0,00256 \\
-0,05625 \\
-0,16814 \\
-0,05625 \\
0,24794 \\
0 \\
0,03664 \\
-0,07834\end{array}$ \\
\hline
\end{tabular}


Tabela 21. Alimentos, Respectivas Quantidades e Atividade Dual das Dietas Obtịdas Através do Modelo Palatāivel para a Família Média da Classe de Renda 4

\begin{tabular}{|c|c|c|}
\hline Al imento & Quantidade & Atividade Dual \\
\hline 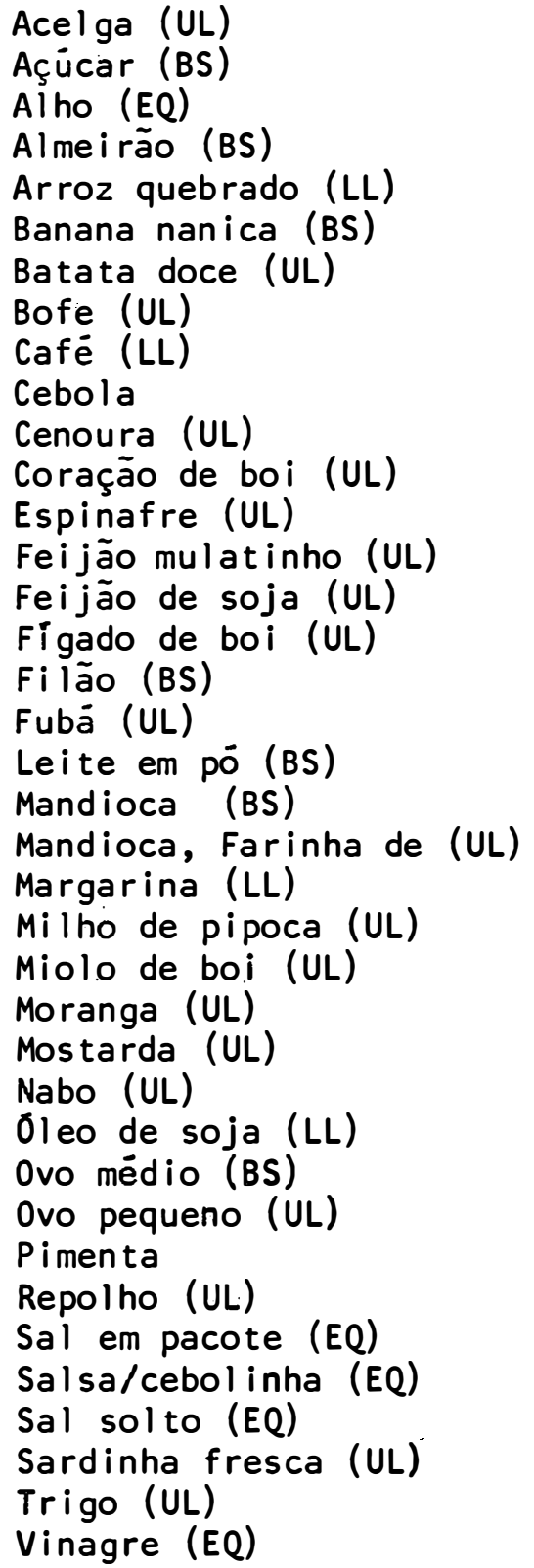 & $\begin{array}{r}9,82100 \\
83,50980 \\
2,84100 \\
14,20711 \\
96,59600 \\
213,93900 \\
5,50900 \\
1,29800 \\
11,38100 \\
21,03800 \\
30,60600 \\
0,62100 \\
9,00500 \\
151,81600 \\
0,71700 \\
3,85400 \\
236,74520 \\
19,22900 \\
65,68818 \\
8,96189 \\
18,61000 \\
3,80000 \\
2,74900 \\
0,52100 \\
2,63700 \\
2,48700 \\
1,55400 \\
28,61900 \\
64,38700 \\
8,71300 \\
0,27100 \\
96,96800 \\
16,74600 \\
3,02900 \\
0,07900 \\
18,60500 \\
0,46600 \\
7,46000\end{array}$ & $\begin{array}{c}0,15648 \\
0 \\
-0,92069 \\
0 \\
-0,03621 \\
0 \\
0,01495 \\
0,26823 \\
-0,37640 \\
-0,11442 \\
0,04254 \\
0,02397 \\
0,05427 \\
0,17332 \\
0,30416 \\
0,77502 \\
0 \\
0,04393 \\
0 \\
0 \\
0,15609 \\
-0,50099 \\
0,03783 \\
0,12807 \\
0,01424 \\
0,07601 \\
0,03158 \\
-0,04772 \\
0 \\
0,04000 \\
-0,96479 \\
0,03569 \\
-0,05656 \\
-0,26425 \\
-0,05656 \\
0,21888 \\
0,03491 \\
-0,07977\end{array}$ \\
\hline
\end{tabular}


Tabela 22. Alimentos, Respectivas Quantidades e Atividade Dual das Dietas Obtidas Através do Modelo Palatável para a Família Média da Classe de Renda 5

\begin{tabular}{|c|c|c|}
\hline Alimento & Quant idade & Atividade Dual \\
\hline 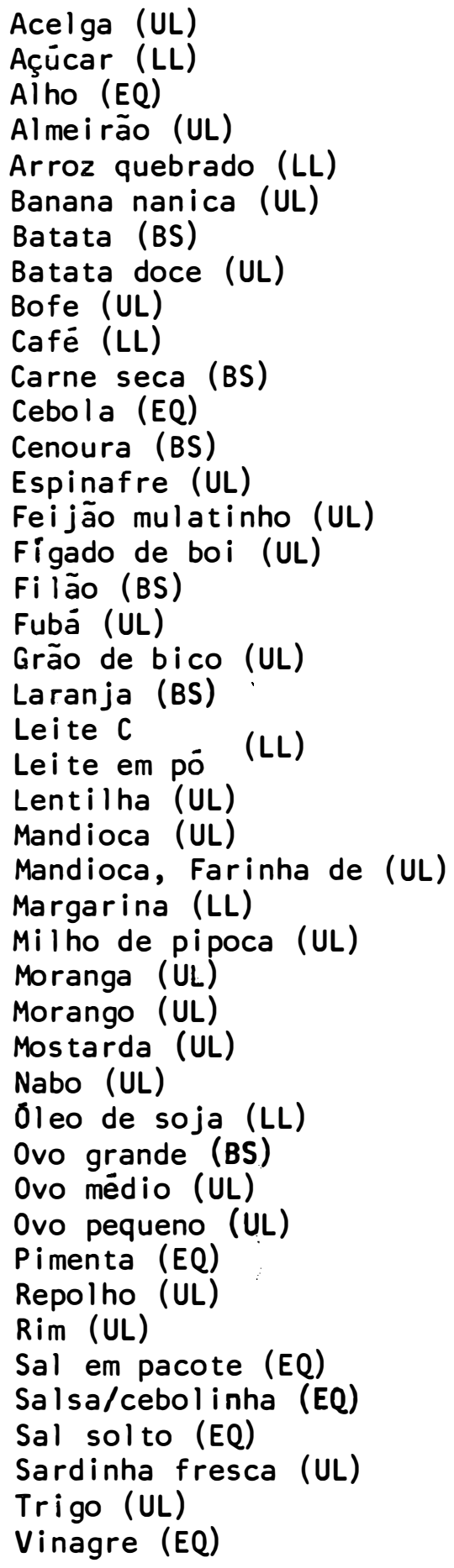 & $\begin{array}{r}8,74500 \\
58,82400 \\
3,48900 \\
20,14300 \\
86,24300 \\
187,62200 \\
8,68125 \\
6,42700 \\
2,18500 \\
13,04700 \\
0,05156 \\
26,15800 \\
20,66975 \\
16,33100 \\
133,35000 \\
5,57600 \\
306,75971 \\
13,50400 \\
1,99300 \\
32,02400 \\
42,06610 \\
1,98700 \\
14,39800 \\
16,96700 \\
4,29900 \\
9,65500 \\
4,13000 \\
22,60500 \\
3,85000 \\
6,54400 \\
33,39000 \\
13,47244 \\
67,84200 \\
10,39600 \\
0,30700 \\
99,60300 \\
0,21900 \\
17,70800 \\
3,55200 \\
0,23100 \\
19,10100 \\
1,09700 \\
8,31100\end{array}$ & $\begin{array}{c}0,23622 \\
-0,06985 \\
-0,90528 \\
0,02889 \\
-0,06819 \\
0,01804 \\
0 \\
0,00734 \\
0,41938 \\
-0,32471 \\
0 \\
-0,09202 \\
0 \\
0,10542 \\
0,32728 \\
0,55259 \\
0 \\
0,00495 \\
0,01203 \\
0 \\
-0,00498 \\
0,03782 \\
0,00902 \\
0,27028 \\
-0,66661 \\
0,04269 \\
0,04249 \\
0,01561 \\
0,16035 \\
0,05553 \\
-0,21582 \\
0 \\
0,02000 \\
0,06000 \\
-0,90814 \\
0,04874 \\
0,62713 \\
-0,05338 \\
-0,22898 \\
-0,05338 \\
0,18768 \\
0,07568 \\
-0,06618\end{array}$ \\
\hline
\end{tabular}


Tabela 23. Alimentos, Respectivas Quantidades e Atividade Dual das Dietas Obtidas Através do Modelo Palatāvel para a Família Média da Classe de Renda 6

\begin{tabular}{|c|c|c|}
\hline Al imento & Quantidade & Atividade Dual \\
\hline 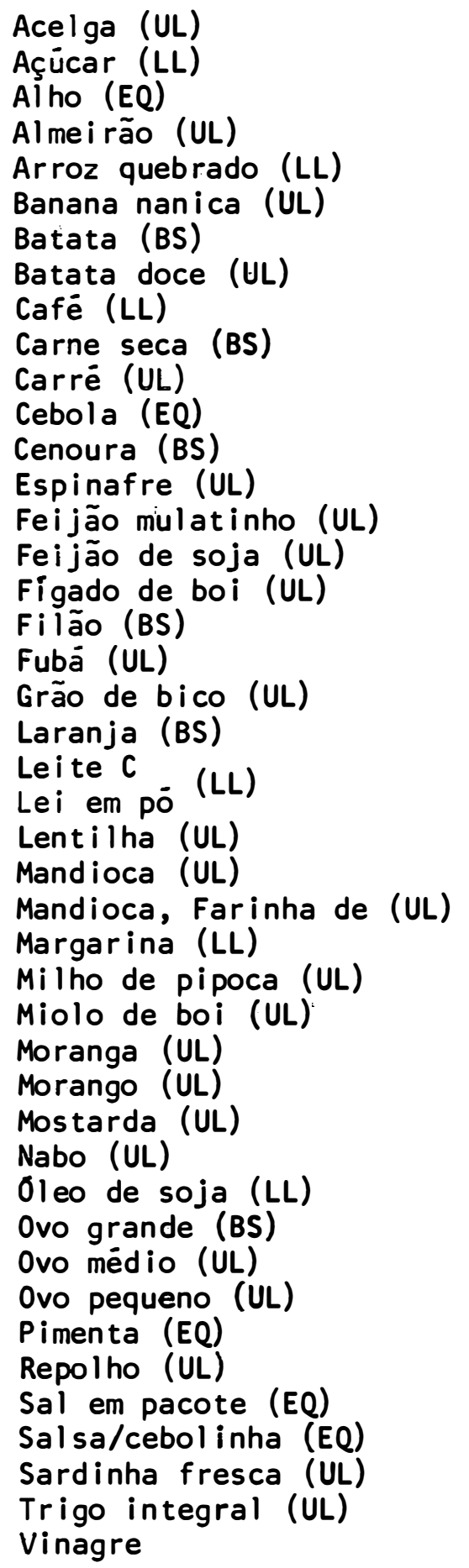 & $\begin{array}{r}6,98700 \\
60,97300 \\
3,66200 \\
17,63400 \\
90,34300 \\
216,83700 \\
36,23850 \\
8,41200 \\
14,04400 \\
0,42234 \\
0,70300 \\
26,67300 \\
6,26750 \\
17,25700 \\
128,61300 \\
4,44400 \\
8,32500 \\
344,78351 \\
15,51500 \\
2,70600 \\
1,03600 \\
177,76070 \\
35,80330 \\
1,55500 \\
23,93900 \\
12,61100 \\
4,81200 \\
3,96000 \\
0,52600 \\
3,86600 \\
52,99000 \\
7,25800 \\
1,40600 \\
36,60800 \\
15,66866 \\
73,45600 \\
6,75400 \\
0,26500 \\
98,14200 \\
17,59200 \\
3,92800 \\
25,55500 \\
1,75300 \\
9,93300\end{array}$ & $\begin{array}{c}0,23622 \\
-0,06985 \\
-0,90528 \\
0,02889 \\
-0,06819 \\
0,01804 \\
0 \\
0,00734 \\
-0,32471 \\
0 \\
0,34748 \\
-0,09202 \\
0 \\
0,10542 \\
0,32728 \\
0,55788 \\
0,55259 \\
0 \\
0,00495 \\
0,01203 \\
0 \\
-0,00498 \\
0,03782 \\
0,00902 \\
0,27028 \\
-0,66661 \\
0,04269 \\
0,16743 \\
0,04249 \\
0,01561 \\
0,16035 \\
0,05553 \\
-0,21582 \\
0 \\
0,02000 \\
0,06000 \\
-0,90814 \\
0,04874 \\
-0,05338 \\
-0,22898 \\
0,18768 \\
0,07568 \\
-0,06618\end{array}$ \\
\hline
\end{tabular}


dietas mais variadas do que o primeiro.

Tem-se tambëm relativa segurança para afirmar que as dietas são condimentadas e estruturadas de acordo com os häbitos da amostra.

Todavia, a restrição que limita o aparecimento de um alimento em quantidade igual a no máximo três vezes o consumo médio, teve um duplo efeito: de um lado forçou a uma maior variedade, na medida em que atingido esse 1 imite o programa de computação procurava outro al imento para satisfazer as restrições, mas por outro lado limitou a variedade e a possibilidade de escolha, principalmente nas classes de menor poder aquisitivo, na medida em que essas classes consomem um nümero menor de a1 imentos.

Isto resultou inclusive em que a dieta planejada para a familia média da classe de renda 1 apresentasse custo superior ao da da classe 2, sendo que deveria ser ao conträrio pois, como jä foi discutido anteriormente, as necessidades nutricionais da familia média crescem com a el evação da classe de renda.

0 ideal seria se, ao invēs de se elaborar as dietas baseados em quantidades compradas, dispusessemos de informaçōes sobre o que os consumidores desejariam ingerir, com que frequência estariam dispostos a fazê-lo, etc. Isto porque, se planejar as dietas baseados em quantidades compradas elimina, pelo menos parcialmente, o perigo de conseguir soluçōes muito diferentes dos hăbitos al imentares, por outro lado, pressupõe 
que os alimentos que não são adquiridos pelos componentes de uma dada classe de renda não teriam boa aceitabilidade, o que pode não ser verdadeiro.

A coluna "Atividade Dual" estä relacionada com a de "reduced cost" (ou preço sombra), mencionada no modelo simples.

Mas tem uma pequena diferença: enquanto o "reduced cost" mostra de quanto seria reduzido o custo da dieta se os limites impostos às variāveis fossem relaxados, ou seja, aumentados caso estivessem no limite superior e diminuidos no inferior, o "dual ativity" mostra de quanto seria reduzido o custo da dieta caso os limites impostos às variäveis fos sem apenas aumentados.

Os alimentos que aparecem nos limites superiores apresentam um valor positivo na "dual ati vity", os que aparecem nos limites inferiores um valor negativo e os que estão no nivel intermediärio valores nulos.

Isto pode ser verificado nas Tabelas 18 a 23 , onde os alimentos que estão nos limites inferiores vêm acompanhados das letras LL, os que estão nos niveis intermediärios, BS, e nos limites superiores UL.

Esta anālise permite verificar para quais alimentos seria mais interessante aumentar os limites impostos. Por exemplo, na dieta obtida para a familla média da classe de renda 2, para cada $100 \mathrm{~g}$ adicionais de figado de boi que pudessem entrar na solução ótima, o custo desta 
80.

se reduziria de $\operatorname{cr} \$ 7,82526$, enquanto que para cada 100 gdicionais de manteiga, o custo da dieta aumentaria de Cr\$0,16576.

Os seguintes alimentos se apresentaram em quase todas as soluçōes ötimas em seus limites superiores: almeirão, batata-doce, espinafre, fígado de boi, fubä, farinha de mandioca, ovo pequeno e repolho.

Os alimentos que apareceram em seus limites inferiores em quase todas as dietas foram: açūcar, arroz, café, manteiga-margarina e öleo de soja.

A Tabela 24 mostra o conteüdo nutricional das dietas elaboradas atravès do "modelo palatável".

Tabela 24. Teor de Nutrientes das Dietas de Custo Minimo Elaboradas Atra vès do Modelo Palatävel

\begin{tabular}{lcccccc}
\hline Nutrientes & \multicolumn{7}{c}{ Classe de Renda } \\
\cline { 2 - 7 } & 1 & 2 & 3 & 4 & 5 & 6 \\
\hline Energia(1000Keal) & 210,68 & 209,95 & 266,21 & 308,47 & 317,81 & 340,88 \\
Proteina (kg) & 7,99 & 8,00 & 9,12 & 10,53 & 11,05 & 11,86 \\
Cälcio (10g) & 12,6 & 12,0 & 9,4 & 10,5 & 10,7 & 11,2 \\
Ferro (g) & 1,54 & 1,63 & 1,95 & 2,23 & 2,38 & 2,52 \\
Retinol (mg) & 53,72 & 61,32 & 75,80 & 88,35 & 93,39 & 98,95 \\
Tiamina (g) & 0,110 & 0,109 & 0,114 & 0,132 & 0,135 & 0,141 \\
Riboflavina (g) & 0,197 & 0,194 & 0,160 & 0,185 & 0,191 & 0,205 \\
Niacina (g) & 2,174 & 2,098 & 2,345 & 2,690 & 2,894 & 3,144 \\
Acido & & & & & & 11,4 \\
Ascórbico (g) & 14,2 & 7,3 & 6,4 & 7,2 & 10,0 & \\
\hline
\end{tabular}


Observa-se, pela comparação dessa tabela com a de nümero 6 , que a energia, ferro, retinol e riboflavina apareceram em quase todas as soluções ottimas em seus limites inferiores, o que significa que caso estes pudessem ser relaxados obter-se-iam reduções em seus custos.

E interessante verificar que o ferro, retinol e a riboflavina foram nutrientes para os quais a disponibilidade de consumo nas seis principais classes de renda foi inferior às recomendações.

Como o modelo palatável foi elaborado para se conseguir uma certa concordância com os hảbitos alimentares da população, isto parece sugerir que esses mesmos häbitos dificultam o atendimento das recomendações desses nutrientes.

0 teor proteico das dietas foi novamente bem superior ao necessārio, reforçando as conclusões obtidas com a solução do modelo simples, no tocante ao custo desse nutriente não ser fator limitante como usualmente se imagina.

4.2.3.2. Anālise pōs-otimização das dietas obtidas atravès do modelo palatável

As informações da anālise de pōs-otimização dessas dietas estão apresentadas no apêndice 4.

As três primeiras colunas mostram os alimentos selecionados, seus preços unitärios e as quantidades obtidas na solução ötima. As demais colunas mostram os preços máximos e minimos permitidos para a 
variävel sem que se altere a solução òtima.

Da mesma maneira descrita na anålise de po̊s-otimização das dietas obtidas atravēs do modelo simples, as informaçōes sobre a estabili dade de um alimento na solução òtima são conseguidas atravēs da comparação entre as variações percentuais nos preços com relação aos preços atuais do produto, e as variações percentuais respectivas na sua quantidade.

A acelga foi o alimento mais estävel face à elevações de preços, sendo que na solução obtida para a familia média da classe de ren da 2 , ela permaneceria na solução na quantidade mencionada com uma el evação de preços de até 15,29 vezes.

De uma maneira geral as dietas obtidas para as familias mé dias das classes de renda 1 e 2 foram menos sensiveis à variações de preços.

\subsubsection{Custo das dietas e renda familiar}

A Tabela 25 evidencia a redução de dispêndios em alimentos que seria conseguida pelas famillias com a adoção das dietas de custo minimo.

Observamse que exceto para a classe de renda 1 , as familias obteriam significativa economia de recursos com a adoção dessas dietas, aliadas ao atendimento das necessidades nutricionais. Apenas a classe de renda de menor poder aquisitivo não poderia adotar a dieta de custo 
minimo pois esta foi mais cara do que a que ela usualmente adquire.

Tabela 25. Custo da Alimentação Adquirida e da Dieta de Custo Mínimo Ela borada Através do Modelo Palatável

\begin{tabular}{|c|c|c|c|c|c|c|c|}
\hline \multirow{2}{*}{$\begin{array}{l}\text { Custos } \\
\text { (Cr\$) }\end{array}$} & \multicolumn{7}{|c|}{ Classe de Renda } \\
\hline & 1 & 2 & 3 & 4 & 5 & 6 & Média \\
\hline $\begin{array}{l}\text { Dietas } \\
\text { Adquiridas }\end{array}$ & 128,14 & 188,13 & 278,34 & 373,73 & 429,27 & 485,12 & 313,79 \\
\hline $\begin{array}{l}\text { Dietas de } \\
\text { Custo Mínimo }\end{array}$ & 152,03 & 142,82 & 159,33 & 188,60 & 210,24 & 227,02 & 180,01 \\
\hline $\begin{array}{l}\text { Excesso de Cus } \\
\text { to da Dieta } \\
\text { Adquirida so- } \\
\text { bre a de Custo } \\
\text { Minimo }\end{array}$ & $-23,89$ & 45,31 & 119,01 & 185,13 & 219,03 & 258,1 & 113,78 \\
\hline
\end{tabular}

Todavia, como jä foi discutido anteriormente, este alto custo poderia ser reduzido caso se dispusesse de informações que possibilitassem a entrada na solução ótima de outros alimentos que são aceitos por familias dos estratos superiores de renda.

Logicamente o custo dessas dietas foi superior ao das elaboradas atravēs do modelo simples, pois quanto mais restrições são adicionadas para observar häbitos al imentares, mais cara se torna a solução ót ima.

Entretanto supōe-se que a melhoria na palatabilidade compensa esse adicional nos custos. 
As percentagens da renda necessärias para a aquisição dessas dietas são apresentadas na Tabela 26 .

Tabela 26. Percentagens das Rendas Necessärias para a Aquisição das Dietas de Custo Minimo Elaboradas Atravès do Modelo Palatāvel

\begin{tabular}{lcccccc}
\hline & \multicolumn{6}{c}{ Classe de Renda } \\
\cline { 2 - 7 } & 1 & 2 & 3 & 4 & 5 & 6 \\
\hline $\begin{array}{l}\text { Renda Familiar } \\
\text { Mensal Mëdia } \\
\text { (Cr\$) }\end{array}$ & 181,76 & 359,76 & 686,72 & 1116,58 & 1569,05 & 2012,36 \\
$\begin{array}{l}\text { Custo Mensal da } \\
\text { Dieta de Custo } \\
\text { Minimo } \\
\text { (Cr\$) }\end{array}$ & 152,03 & 142,82 & 159,33 & 188,60 & 210,24 & 227,02 \\
$\begin{array}{l}\% \text { da Renda a } \\
\text { Ser Gasta em }\end{array}$ & 83,64 & 39,70 & 23,20 & 16,89 & 13,40 & 11,28 \\
\hline Alimentos & & & & & & \\
\hline
\end{tabular}

Ve-se que as familias de todas as classes de renda, exceto as da primeira, poderiam adquirir as dietas correspondentes às soluçōes ótimas do ponto de vista orçamentärio, pois elas não implicam em percentagens muito el evadas da renda na compra de al imentos. 
5. CONCLUSOES

A anälise dos resultados obtidos permite elaborar as conclusöes que seguem.

Os individuos incluidos nos estratos de menor renda apresentaram disponibilidade inferior às recomendações para ferro, retinol, tiamina e riboflavina. Este fato, isoladamente, não prova a existência de deficiências desses nutrientes, mas sugere que elas devem estar presentes.

Quando se analisou a alimentação adquirida no que se refere à eficiência, ou seja, grau em que os nutrientes obtidos são adquiridos pelo menor custo, verificou-se que os indices foram extremamente baixos, sugerindo que a população estudada ou desconhece as noções bäs cas de nutrição ou não considera o problema nutricional como prioritärio.

As dietas de custo mínimo obtidas atravēs do modelo simples, ou seja, o que estabelecia restrições relativas apenas às necessidades de nutrientes, apresentaram custo värias vezes menor do que o das 
dietas compradas pelos componentes da população estudada, sendo que mesmo as familias da classe de menor poder aquisitivo poderiam adquiriolas dentro de suas restrições orçamentärias. Entretanto, a aceitação dessas dietas implicaria em mudança radical nos häbitos alimentares, pois as soluções encontradas não incluíam condimentos, tinham composição pouco variada, alèm de que os al imentos que as compunham estavam presentes em quantidades excessivas. Aliås, pela literatura observa-se que todas as dietas obtidas atravès desse modelo apresentam basicamente as mesmas limitações, o que dả ao modelo interesse apenas teörico.

Jả o modelo palatåvel foi baseado na pressuposição de que - grau de aceitação de uma dieta estã em função de sua semelhança com a alimentação usual. Portanto, o conjunto de pestrições estabelecidas objetivou uma solução ötima cujos alimentos e respectivas quantidades estivessem dentro de limites impostos pelas informações de compra dos consumidores.

As soluções obtidas atravës deste modelo, embora mais caras do que as do modelo simples, tiveram, de um modo geral, custo consideravelmente inferior ao da alimentação adquirida pelas familias em questão. Apenas as famílias da classe de renda 1 não teriam condiçōes econômicas de adquiri-la, pois para tal, necessitariam dispen der $83,64 \%$ de sua renda em alimentos, valor esse inclusive maior do que aquele que estavam gastando. Para as demais classes, as percentagens da renda necessärias para a aquisição dessas dietas são menores do que as usuais e, segundo o conceito de AMARAL (1963) sobre o "orça mento doméstico satisfatörio", são viāveis, pois, em nenhuma classe 
ultrapassam $50 \%$ da renda. Pode-se concluir, portanto, que atravës desse modelo se consegue soluçōes que levam a uma melhor alocação dos recursos familiares, alèm de que as dietas obtidas são adequadas no aspecto nutri cional e presumivelmente aceitåveis pela semelhança que guardam com a alimentação usual.

Entretanto, o modelo tambẻm apresenta limitações, pois restringir a solução ótima pelas quantidades de alimentos comprados implica em pressupor que os alimentos que não são usualmente consumidos não teriam boa aceitabilidade, o que talvez não seja verdade. Isto inclusive ocasionou que a dieta planejada para a famillia média da classe de menor poder aquisitivo tivesse custo mais elevado do que a da classe de renda imediatamente acima, o que não deveria acontecer pois os requisitos de nutrientes da primeira eram menores. Tal fato ocorreu porque a maior variedade de itens alimentares, comprados pelas familias da segunda classe, possibilitou maior flexibilidade ao programa de computação na busca da solução de custo mininimo. Essas considerações levam a conclusão de que o ideal seria dispormse de informações sobre as preferências dos consumidores e não apenas sobre o seu consumo. Isto inclusive eliminaria a arbitrariedade na determinação de alguns coeficientes. Entretanto, tal metodologia não pode ser adotada pela inexistência desses dados.

Todavia, a despeito das limitações da metodologia utilizada, os resultados obtidos mostram que a programação linear ẻ um instrumento valioso para a elaboração de dietas humanas palatåveis, e que um programa de educação alimentar baseado nesses resultados levaria à melhoria das condições nutricionais da população em apreço. 
88.

6. SUMMARY

The main objectives of the present study were: (1) to analyze the nutritional adequacy of nutrition habits of a sample of families in the city of São Paulo, and (2) to determine diets that were adequate nutritionally, palatable and that satisfied certain eating habits of the mentioned sample.

The necessary data were obtained from the Research on Family Budgets in the City of São Paulo. This study was conducted in the period August 1971 to July 1972, and collected information on the food consumption patterns of 2380 families.

This information was collected by family but was presented grouped into fourtenn family income classes.

FAO recommendations, adapted to average annual temperatures in the region, were taken in order to establish the nutritional needs. 
The results disclosed the existence of a direct relationship between income and food adequacy. The first six classes presented significant nutritional deficiencies, especially in relation to iron, retinol, thiamine and riboflavine.

Next, minimum cost diets which met the nutritional needs of the average families of these six income classes were calculated, using the linnear programming technique. The computer program utilized provided minimum cost diets and also an analysis of the sensitivity indicating what modifications the optimal solution may have as a result of changes in food prices.

The optimal solutions obtained, in addition to meeting the nutritional recommendations for the population analyzed, also presented costs that were markedly lower than those of the foods usually consumed, for all income strata. However, these results presented limitations which prevented their acceptance, such as, little variety together with the inclusion of high quantities of one food and the exclusion of spices.

A second model was formulated which considered the nutritional needs of the population and also established a wide number of restrictions with a view to obtaining diets structured according to the eating habits of the sampled population, that were palatable and presented a reasonable variety and were adequately seasoned.

The cost of the diets obtained by using the second model was considerably hlgher than that of the diets obtained by using the first 
model. However, it was still lower than that of the diet usually consumed, except in the case of the lower purchasing power class.

Although it was not possible to test the acceptability of this diet, it is believed to be reasonably acceptable, since the restrictions stipulated aimed at obtaining a certaln conformity with the food usually eaten. 
7. BIBLI OGRAFIA

ALMEIDA, J.R. de, 1940. Alcool e Destilaria. Piracicaba, Editora Natanael dos Santos. 333 p.

AMARAL, P. de, 1963. O Problema da Al imentação. Rio de Janeiro, Livraria José Olympio, Vol. I, 325 p.

BALINTFY, J.L., 1964. Menu Planing by Computer. Association for Computing Machinery Commun, 7:255-259.

BERG, A., 1973. The Nutrition Factor. Washington, D.C., The Brookings Institution. $290 \mathrm{p}$.

CAMPINO, A.C.C. e E.L.G.ALVES, 1974. Fatores Sócio-Econômicos Associados à Nutrição no Municipio de São Paulo. In: 11 Encontro Anual da Associação Nacional de Centros de Pós-Graduação em Economia. Minas Gerais. CEDEPLAR/UFMG. $30 \mathrm{p}$.

CHRISTENSEN, R.P. 1943. Using Resources to Meet Food Needs. Washington, D.C. U.S. Department of Agriculture Bureau of Agricultural Economics, U.S. Government Printing Office. 
BRASIL. Fundação Instituto Brasileiro de Geografia e Estatística, 1968. Anuário Estatístico, Rio de Janeiro, Vol. 29.

BRASIL. Fundação Instituto Brasileiro de Geografia e Estatística, 1969. Anuärio Estatístico, Rio de Janeiro, 720 p. Vol. 30.

BRASIL. Fundação Instituto Brasileiro de Geografia e Estatística, 1970. Anuärio Estatístico, Rio de Janeiro, 772 p. Vol. 31.

BRASIL. Ministērio da Saúde. Comissão Nacional de Alimentação, 1961 . Estudo da Alimentação e das Condições Econômico-Sociais Realizado no Povoado de Currais, Município de Nisia Floresta - Rio Grande do Norte (Brasil), Agos to de 1961 .

BRASIL. Ministērio da Saúde. Comissão Nacional de Alimentação, 1960. Estudo de Consumo de Alimentos e das Condições Söcio-Econômicas das Familias Representativas do Povoado de Boacica, Município de Louros, Rio Grande do Norte, Brasil, Novembro de 1960.

BRASIL. Ministério da Saúde. Comissão Nacional de Alimentação, 1959. Inquērito de Alimentação Realizado em Santo Antonio, Estado do Rio. Grande do Norte (Brasil), Novembro de 1959.

BRASIL. Ministērio da Saúde. Comissão Nacional de Alimentação, 1961 . Inquérito sobre Häbitos e Recursos Al imentares, São Paulo do Potengi, Rio Grande do Norte, Brasil.

DEPARTAMENTO INTERS INDICAL DE ESTATISTICA E ESTUDOS SOCIO-ECONOMICOS, São Paulo, 1972. Boletim n? 2.

DAVIS, J.G., 1965. The Nutritional Index and the Economic Nutritional Index of Foods. Dairy Industries. EUA, 30:193-197. 
DORFMAN, R.; P.A.SAMUELSON E R.M.SOLOW, 1958. Linear Programming and Economic Analysis, New York, RAND Corporation, Mc Graw-Hill Book Company, Inc. 525 p.

ESCUDERO, P. 1968. Las Leyes de la Alimentacion. In: VeLOSO, C.S. Trinta Regimes Alimentares. Rio de Janeiro, Ed. Leitura.

ESTAC10, F.B. de S. 1961. Técnica de Programação Linear. Lisboa, Fundação Calouste Gulbenkian. $214 \mathrm{p}$.

PASSMORE, R.; B.M.NICOL; M.NARAYANARAO, 1974. Handbook on Human Nutritional Requirements. ROMA: FAO Nutritional Studies n: 28. WHO Monograph Series n: 61 .

FOOD AND AGRICULTURE ORGANIZATION/WORLD HEALTH ORGANIZATION, ROMa, 1965.

Protein Requirements. FAO Nutrition Meetings Report Series n: 37. WHO Technical Report Series n: 301.

FOOD AND AGRICULTURE ORGANIZATION/WORLD HEALTH ORGANIZATION, ROMa, 1973. Energy and Protein Requirements. FAO Nutrition Meetings Report Series n: 52. WHO Technical Report Series n: 322.

FLORENCI0, C. e V.E.SMITH, 1967. Efficiency of Food Purchasing Among Working-Class Families in Colombia. Journal of the American Dietetic. Association. 55:239-245.

GELPI, M.J.; J.L.BALINTFY; L.C.DENNIS e I.K.FINDORFF, 1972. Integrated nutrition and food cost control by computer. Journal of the American Dietetic Association. 6l:637-646.

GOLDSMITH, G.A., 1969. World Food Supply and Population Increase. In: Proceedings Western Hemisphere Nutrition Congress 11 - 1968. Chicago, American Medical Association. 
IBM, N. YORK. 1968. 1130 Linear Programming. 3a. ed. IBM Technical Publications Department.

KIRSTEN, J.T. e outros. 1973. Orçamentos Familiares na Cidade de São Paulo. São Paulo, Instituto de Pesquisas Econômicas, 246 p. (Série Monografias, 3).

LAURENTI, R. 1973. Alguns Aspectos da Mortalidade de Crianças Menores de 5 Anos em Três Áreas Brasileiras - Trabalho apresentado na 259 Reunião da SBPC.

LOPES, L.J. 1966. Programação Linear. Rio de Janeiro, Divisão de Documentação e Informação da Universidade Rural do Brasil. 36 p.

MARTINS, I.S. e outros. 1977. Relação entre Consumo Alimentar e Renda Familiar na Cidade de Iguape. Revista de Saúde Pública. São Paulo, $11: 27-38$.

MC MICHAEL, C.E. A A.E.BAILEY, 1951. Edible Fats and Oils. In: JACOBS, M.B. The Chemistry and Tecnology of Food and Food Products. 2a. ed. New York, Interscience Publishers. Vol. 2. p. 365-417.

OMETTO, A.M.H.; M.S.do CARMO e N.M.S.FIGUEIREDO, 1974. Dietas de Custo Minimo Para a Região de Ribeirão Preto. Série Pesquisa n? 26. Piracicaba. Departamento de Ciências Sociais Aplicadas, ESALQ/USP. 63 p.

OMETTO, A.M.H.; B.de C.VICTORIA; E.E.M.COSTA; M.A.M.FIORE e M.I.PASSI NI, 1977. Tabela de Composição Química dos Alimentos. Piracicaba, Departamento de Tecnologia dos Alimentos, ESALQ/USP.

SIMÕES, M.H.R., 1969. Dietas Adequadas de Custo Minimo em Cristalina, Estado de Goiàs. Viçosa, UREMG, 63 p. 
SIQUEIRA, P.B., 1968. Nível de Salário e Alimentação em Belo Horizonte. In: II Simpósio Brasileiro de Alimentação e Nutrição. Belo Horizonte, Mimeografado. $3 p$.

SMITH, V.E., 1959. Linear Programing Model for the Determination of Palatable Human Diets. Journal of Farm Economics. Wisconsin, XLL, n? 2.

SMITH, V.E., 1964. Eletronic Computation of Human Diets. East Lansing: Division of Research, Graduate School of Business Administration, Michigan State University.

SOBOLL, M.L. de M.S., 1973. Nivel Alimentar da População Trabalhadora da Cidade de São Paulo. DIEESE em Resumo. São Paulo, 1: 32 .

STIGLER, G.J., 1945. The Cost of Subsistence. Journal of Farm Economics. Wisconsin. 27:303-314.

TERROINE, E.F., 1962. Valeur Aliméntaire et Coût des Denrées. Annales de la Nutrition et de l'Aliméntation. 16:91-172.

THEIL, H.; J.BOOT e T.KLOEX, 1965. Operations Research and Quantitative, Economics an Elementary Introduction. New York, McGraw Hill Book Com pany. $258 \mathrm{p}$.

TREMOLIERES, J.; Y.SERVILLE e R.JACQUOT, 1962. La Pratique de l'Aliméntation. 2a. ed. Paris, Les Edition Sociales Françaises. Vol. 3. 


$$
\text { APENDICES }
$$




\section{Apêndice 1}

Tabela 27. Informação Bāsica

\begin{tabular}{|c|c|c|c|}
\hline Al imen to & Un i dade & $\begin{array}{l}\text { Peso da Unidade } \\
\text { (em } 100 \mathrm{~g})\end{array}$ & $\begin{array}{c}\text { Preço } \\
\text { (de } 100 \mathrm{~g})\end{array}$ \\
\hline Abacate & un idade & 0,50 & 0,08 \\
\hline Abacaxi & un i dade & 19,00 & 0,06 \\
\hline Aböbora & qui lograma & 10,00 & 0,09 \\
\hline Abobrinha & qui lograma & 10,00 & 0,11 \\
\hline Acel ga & pé & 20,00 & 0,03 \\
\hline Acem & qui lograma & 10,00 & 0,47 \\
\hline Açūcar & qui lograma & 10,00 & 0,10 \\
\hline Agrião & maço & 3,00 & 0,24 \\
\hline Aguardente & garrafa & 5,70 & 0,23 \\
\hline Alcachofra & un i dade & 1,20 & 0,40 \\
\hline Alcatra & qui lograma & 10,00 & 0,69 \\
\hline Alface & $\mathrm{pē}$ & 2,50 & 0,15 \\
\hline Alho & quilograma & 10,00 & 1,00 \\
\hline Almeirão & maço & 5,00 & 0,12 \\
\hline Ame i xa & qui lograma & 10,00 & 0,33 \\
\hline Amêndoa & qui lograma & 10,00 & 1,04 \\
\hline Arroz, creme de & caixa & 2,00 & 0,34 \\
\hline Arroz empacotado & qui lograma & 10,00 & 0,22 \\
\hline Arroz quebrado & qui lograma & 10,00 & 0,17 \\
\hline Arroz solto & qui lograma & 10,00 & 0,19 \\
\hline Atum fresco & qui lograma & 10,00 & 0,70 \\
\hline Aveia & qui lograma & 10,00 & 0,56 \\
\hline Avelã & qui lograma & 10,00 & 1,16 \\
\hline Azeite estrangeiro & lata & 8,74 & 0,64 \\
\hline Aze i tona & qui lograma & 10,00 & 0,87 \\
\hline Bacalhau & qui lograma & 10,00 & 0,96 \\
\hline Bala & pacote & 4,07 & 0,44 \\
\hline Banana maçã & dúzia & 10,00 & 0,11 \\
\hline
\end{tabular}


Tabela 27. (continuação)

\begin{tabular}{|c|c|c|c|}
\hline Al imento & Unidade & $\begin{array}{c}\text { Peso da Unidade } \\
\text { (em } 100 \mathrm{~g})\end{array}$ & $\begin{array}{c}\text { Preço } \\
\text { (de } 100 \mathrm{~g})\end{array}$ \\
\hline Banana nanica & dúzia & 13,00 & 0,04 \\
\hline Banha & qui lograma & 10,00 & 0,40 \\
\hline Batata comum & quilograma & 10,00 & 0,09 \\
\hline Batata doce & quilograma & 10,00 & 0,09 \\
\hline Batatinha & qui lograma & 10,00 & 0,10 \\
\hline Bengala & un idade & 3,00 & 0,22 \\
\hline Beringela & qui lograma & 10,00 & 0,14 \\
\hline Beterraba & maço & 3,00 & 0,25 \\
\hline Bofe & quilograma & 10,00 & 0,17 \\
\hline Bolacha cream crackers & pacote & 2,00 & 0,65 \\
\hline Bolacha āgua e sal & pacote & 2,00 & 0,61 \\
\hline Bolacha maria & pacote & 2,00 & 0,52 \\
\hline Bolacha maizena & pacote & 2,00 & 0,54 \\
\hline Bolo de forma & un idade & 4,00 & 0,46 \\
\hline Bombom & pacote & 4,07 & 0,68 \\
\hline Braço & qui lograma & 10,00 & 0,52 \\
\hline Brocoli & maço & 8,00 & 0,17 \\
\hline Bucho & qui lograma & 10,00 & 0,32 \\
\hline Cabrito & qui lograma & 10,00 & 0,61 \\
\hline Cação & quilograma & 10,00 & 0,62 \\
\hline Café & quilograma & 10,00 & 0,54 \\
\hline Cajú & un idade & 0,70 & 0,27 \\
\hline Caldo de galinha/carne & caixa & 0,32 & 1,65 \\
\hline Camarão fresco & quilograma & 10,00 & 1,00 \\
\hline Camarão em pacote & pacote & 1,50 & 1,84 \\
\hline Camarão Rosa & qui lograma & 10,00 & 1,97 \\
\hline Capa de filé & qui lograma & 10,00 & 0,49 \\
\hline Caquí & un idade & 1,90 & 0,10 \\
\hline Carne moida & qui lograma & 10,00 & 0,52 \\
\hline
\end{tabular}


Tabela 27. (continuação)

\begin{tabular}{|c|c|c|c|}
\hline Al imento & Unidade & $\begin{array}{l}\text { Peso da Unidade } \\
\text { (em 100g) }\end{array}$ & $\begin{array}{l}\text { Preço } \\
\text { (de } 100 \mathrm{~g})\end{array}$ \\
\hline Carne seca & qui lograma & 10,00 & 0,77 \\
\hline Carrē & qui lograma & 10,00 & 0,57 \\
\hline Castanha portuguêsa & qui lograma & 10,00 & 0,85 \\
\hline Castanha do Parā & qui lograma & 10,00 & 0,93 \\
\hline Catupiri & caixa & 5,00 & 0,46 \\
\hline Cebola & qui lograma & 10,00 & 0,16 \\
\hline Cenoura & qui lograma & 10,00 & 0,14 \\
\hline Cerveja & garrafa & 6,60 & 0,22 \\
\hline Cerveja (meia) & garrafa & $3 ; 30$ & 0,36 \\
\hline Champanhe & garrafa & 6,50 & 1,18 \\
\hline Chocolate em pō & caixa & 4,07 & 0,38 \\
\hline Chuchu & qui lograma & 10,00 & 0,08 \\
\hline Cidra & garrafa & 6,50 & 0,56 \\
\hline Côco, Leite de & vidro & 2,00 & 0,72 \\
\hline Coel ho & qui lograma & 10,00 & 1,79 \\
\hline Conhaque & garrafa & 8,53 & 0,59 \\
\hline Contra filé & quilograma & 10,00 & 0,75 \\
\hline Coração de boi & qui lograma & 10,00 & 0,44 \\
\hline Costela de boi & qui lograma & 10,00 & 0,70 \\
\hline Costela de porco & qui lograma & 10,00 & 0,72 \\
\hline Couve & maço & 5,00 & 0,13 \\
\hline Couve-flor & pè & 12,50 & 0,08 \\
\hline Coxão duro & qui lograma & 10,00 & 0,63 \\
\hline Coxão mole & qui lograma & 10,00 & 0,66 \\
\hline Creme de leite & lata & 3,00 & 0,32 \\
\hline Ervilha fresca & quil lograma & 10,00 & 0,24 \\
\hline Ervilha em lata & lata & 3,09 & 0,29 \\
\hline Escarola & pë & 1,90 & 0,23 \\
\hline Espinafre & maço & 8,00 & 0,10 \\
\hline
\end{tabular}


Tabela 27. (continuação)

\begin{tabular}{|c|c|c|c|}
\hline Al imento & Unidade & $\begin{array}{l}\text { Peso da Unidade } \\
(\text { em } 100 \mathrm{~g})\end{array}$ & $\begin{array}{c}\text { Preço } \\
\text { (de } 100 \mathrm{~g})\end{array}$ \\
\hline Farinha de rosca & quilograma & 10,00 & 0,18 \\
\hline Farinha de trigo & quilograma & 10,00 & 0,13 \\
\hline Feijão branco & quilograma & 10,00 & 0,76 \\
\hline Feijão jalo & quilograma & 10,00 & 0,17 \\
\hline Feijão mulatinho & qui lograma & 10,00 & 0,16 \\
\hline Feijão empacotado & qui lograma & 10,00 & 0,21 \\
\hline Feijão preto & quilograma & 10,00 & 0,85 \\
\hline Feijão roxinho & quilograma & 10,00 & 0,19 \\
\hline Fei jão roxão & qui lograma & 10,00 & 0,16 \\
\hline Feijão soja & quilograma & 10,00 & 0,17 \\
\hline Figado de boi & qui lograma & 10,00 & 0,59 \\
\hline Figo & caixa & 10,00 & 0,19 \\
\hline Figo cristalizado & pacote & 5,00 & 0,68 \\
\hline Figo em calda & lata & 6,74 & 0,56 \\
\hline Filão & unidade & 5,50 & 0,15 \\
\hline Filé mignon & quilograma & 10,00 & 1,15 \\
\hline Frango/gal inha & qui.lograma & 10,00 & 0,50 \\
\hline Fubá & quilograma & 10,00 & 0,09 \\
\hline Gim & litro & 9,51 & 0,74 \\
\hline Goiaba & un idade & 1,80 & 0,13 \\
\hline Goiabada & lata & 7,66 & 0,34 \\
\hline Grão de bico & quilograma & 10,00 & 0,49 \\
\hline Inhame & quilograma & 10,00 & 0,14 \\
\hline Jaboticaba & quilograma & 10,00 & 0,17 \\
\hline Lagar to & quilograma & 10,00 & 0,66 \\
\hline Laranja & düzia & 19,20 & 0,06 \\
\hline Leite tipo $B$ & litro & 10,30 & 0,12 \\
\hline Leite tipo C & litro & 10,32 & 0,07 \\
\hline Leite condensado & lata & 3,95 & 0,43 \\
\hline
\end{tabular}


Tabela 27. (continuação)

\begin{tabular}{|c|c|c|c|}
\hline Al imento & Unidade & $\begin{array}{c}\text { Peso da Unidade } \\
\text { (em } 100 \mathrm{~g})\end{array}$ & $\begin{array}{c}\text { Preço } \\
\text { (de } 100 \mathrm{~g})\end{array}$ \\
\hline Leite em pö & lata & 10,53 & 0,37 \\
\hline Lentilha & quilograma & 10,00 & 0,47 \\
\hline Limão galêgo & dúzia & 5,00 & 0,18 \\
\hline Limão (outros) & dúzia & 12,00 & 0,16 \\
\hline Lingua & quilograma & 10,00 & 0,50 \\
\hline Linguiça & quilograma & 10,00 & 0,81 \\
\hline Lombo de porco & quilograma & 10,00 & 1,13 \\
\hline Maçã dura & quilograma & 10,00 & 0,11 \\
\hline Maçã estrangeira & un idade & 2,00 & 0,21 \\
\hline Macarrão fresco & quilograma & 10,00 & 0,46 \\
\hline Macarrão & pacote & 10,00 & 0,37 \\
\hline Ma i zena & caixa & 4,61 & 0,14 \\
\hline Mamão & unidade & 18,00 & 0,09 \\
\hline Mandioca & quilograma & 10,00 & 0,09 \\
\hline Mandioca, Farinha de & quilograma & 10,00 & 0,12 \\
\hline Mandi oqu inha & quilograma & 10,00 & 0,17 \\
\hline Manga & unidade & 2,50 & 0,08 \\
\hline Manteiga & qui lograma & 10,00 & 1,12 \\
\hline Maracu jā & unidade & 1,00 & 0,21 \\
\hline Margarina & pacote & 2,81 & 0,72 \\
\hline Marisco & quilograma & 10,00 & 0,19 \\
\hline Marmelada & lata & 7,66 & 0,35 \\
\hline Melancia & quilograma & 10,00 & 0,06 \\
\hline Melão estrangeiro & quilograma & 10,00 & 0,36 \\
\hline Melão nacional & quilograma & 10,00 & 0,28 \\
\hline Mexerica & dūzia & 16,00 & 0,09 \\
\hline Milho, Farinha de & quilograma & 10,00 & 0,16 \\
\hline Milho de pipoca & quilograma & 10,00 & 0,14 \\
\hline Milho verde & unidade & 4,70 & 0,06 \\
\hline
\end{tabular}


Tabela 27. (continuação)

\begin{tabular}{|c|c|c|c|}
\hline Alimento & Unidade & $\begin{array}{l}\text { Peso da Unidade } \\
\text { (em } 100 \mathrm{~g})\end{array}$ & $\begin{array}{l}\text { Preço } \\
\text { (de } 100 \mathrm{~g})\end{array}$ \\
\hline Miolo de boi & qui lograma & 10,00 & 0,22 \\
\hline Moranga & qui lograma & 10,00 & 0,07 \\
\hline Morango & caixa & 40,00 & 0,08 \\
\hline Mortadela & qui lograma & 10,00 & 0,81 \\
\hline Mostarda & maço & 8,00 & 0,10 \\
\hline Músculo & qui lograma & 10,00 & 0,54 \\
\hline Mussarela & qui lograma & 10,00 & 0,86 \\
\hline Nabo & maço & 20,00 & 0,04 \\
\hline Nozes & qui lograma & 10,00 & 1,14 \\
\hline Oleo de algodão & lata & 11,21 & 0,29 \\
\hline Oleo de amendoim & lata & 11,20 & 0,31 \\
\hline Oleo de arroz & lata & 11,21 & 0,32 \\
\hline Oleo de girassol & lata & 11,24 & 0,34 \\
\hline Oleo de litro & lata & 9,22 & 0,29 \\
\hline Oleo de oliva + amendoim & lata & 11,15 & 0,35 \\
\hline Oleo de mi lho & lata & 11,23 & 0,39 \\
\hline Oleo de soja & lata & 11,25 & 0,27 \\
\hline Ovo grande & dúzia & 6,90 & 0,34 \\
\hline Ovo médio & dūzia & 6,30 & 0,32 \\
\hline Ovo pequeno & dūzia & 5,70 & 0,28 \\
\hline Palmi to & un idade & 15,00 & 0,15 \\
\hline Palmito em lata & lata & 4,41 & 0,60 \\
\hline Pão de forma & unidade & 4,00 & 0,34 \\
\hline Pãozinho (francês) & unidade & 0,50 & 0,25 \\
\hline Patê & lata & 1,45 & 1,22 \\
\hline Pat inho & quilograma & 10,00 & 0,65 \\
\hline Pato & qui lograma & 10,00 & 0,40 \\
\hline Peito de boi & qui lograma & 10,00 & 0,41 \\
\hline Pepino & quilograma & 10,00 & 0,09 \\
\hline Pera estrangeira & unidade & 2,00 & 0,29 \\
\hline
\end{tabular}


Tabela 27. (continuação)

\begin{tabular}{|c|c|c|c|}
\hline Alimento & Un idade & $\begin{array}{l}\text { Peso da Unidade } \\
\text { (em } 100 \mathrm{~g})\end{array}$ & $\begin{array}{c}\text { Preço } \\
\text { (de } 100 \mathrm{~g})\end{array}$ \\
\hline Pera nacional & quilograma & 10,00 & 0,06 \\
\hline Pernil & quilograma & 10,00 & 0,61 \\
\hline Perú & quilograma & 10,00 & 0,61 \\
\hline Pescada & quilograma & 10,00 & 0,46 \\
\hline Pessego & unidade & 1,00 & 0,30 \\
\hline Pessego em calda & lata & 6,74 & 0,53 \\
\hline Pimenta, coloral & pacote & 0,25 & 1,73 \\
\hline Pimentão & unidade & 1,20 & 0,13 \\
\hline Presuntada-fiambrada & lata & 3,20 & 0,95 \\
\hline Presunto & qui lograma & 10,00 & 1,33 \\
\hline Provolone & quilograma & 10,00 & 1,01 \\
\hline Queijo para ralar & qui ilograma & 10,00 & 0,76 \\
\hline Queijo fresco & qui lograma & 10,00 & 0,78 \\
\hline Queijo prato & qui lograma & 10,00 & 0,73 \\
\hline Quiabo & qui lograma & 10,00 & 0,20 \\
\hline Rabanete & maço & 5,00 & 0,16 \\
\hline Refrigerante grande & garrafa & 3,35 & 0,25 \\
\hline Refrigerante pequeno & garrafa & 2,10 & 0,22 \\
\hline Repolho & pë & 20,00 & 0,03 \\
\hline Requei jão & copo & 2,55 & 0,93 \\
\hline Ricota & quilograma & 10,00 & 0,61 \\
\hline Rim & qui lograma & $1.0,00$ & 0,14 \\
\hline Rosbife & quilograma & 10,00 & 1,01 \\
\hline Rum & litro & 9,51 & 0,68 \\
\hline Salame-salaminho & un idade & 3,70 & 1,29 \\
\hline Sal empacotado & quilograma & 10,00 & 0,06 \\
\hline Salsa/cebolinha & maço & 1,00 & 0,38 \\
\hline Salsicha & quilograma & 10,00 & 0,85 \\
\hline Sal sol to & quilograma & 10,00 & 0,06 \\
\hline
\end{tabular}


Tabela 27. (cont inuação)

\begin{tabular}{lrrr}
\hline Alimento & Unidade & $\begin{array}{c}\text { Peso da Unidade } \\
(\mathrm{em} \mathrm{100g})\end{array}$ & $\begin{array}{c}\text { Preço } \\
\text { (de 100g) }\end{array}$ \\
\hline Sardinha fresca & quilograma & 10,00 & 0,14 \\
Sardinha em lata & lata & 1,34 & 0,77 \\
Tâmara & pacote & 2,25 & 1,83 \\
Toddy, Nescau & lata & 4,07 & 0,71 \\
Tomate & qui lograma & 10,00 & 0,11 \\
Tomate, Extrato de & lata & 2,03 & 3,78 \\
Toucinho defumado & qui lograma & 10,00 & 0,86 \\
Toucinho fresco & qui lograma & 10,00 & 0,36 \\
Trigo & qui lograma & 10,00 & 0,18 \\
Uva & qui lograma & 10,00 & 0,15 \\
Vagem & quilograma & 10,00 & 0,17 \\
Vermouth & litro & 9,85 & 0,39 \\
Vinagre & litro & 10,04 & 0,10 \\
Vinho & litro & 9,85 & 0,29 \\
Vodka & litro & 9,44 & 0,80 \\
Wisky & litro & 9,44 & 2,85 \\
& & & \\
\hline
\end{tabular}


105.

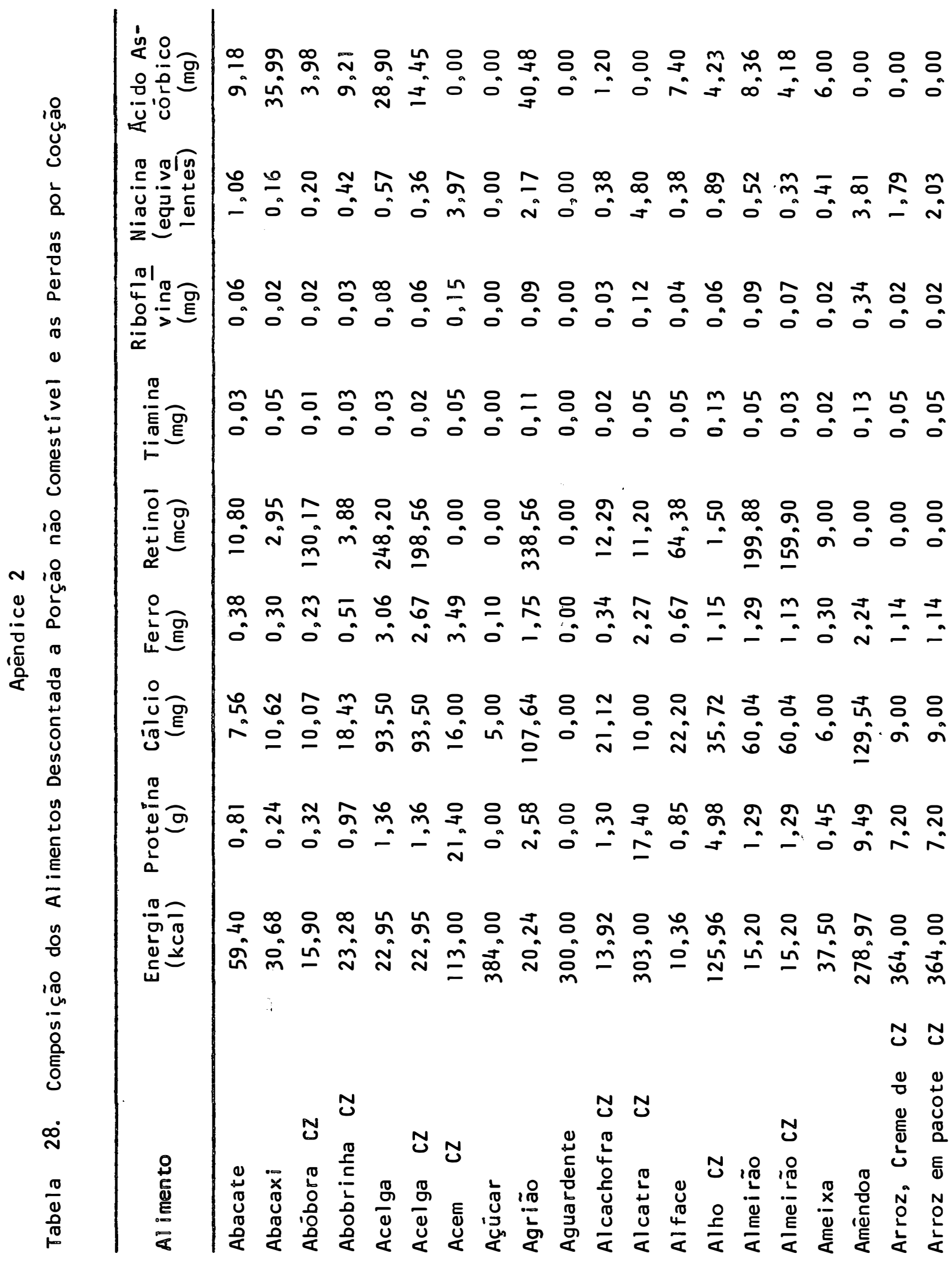




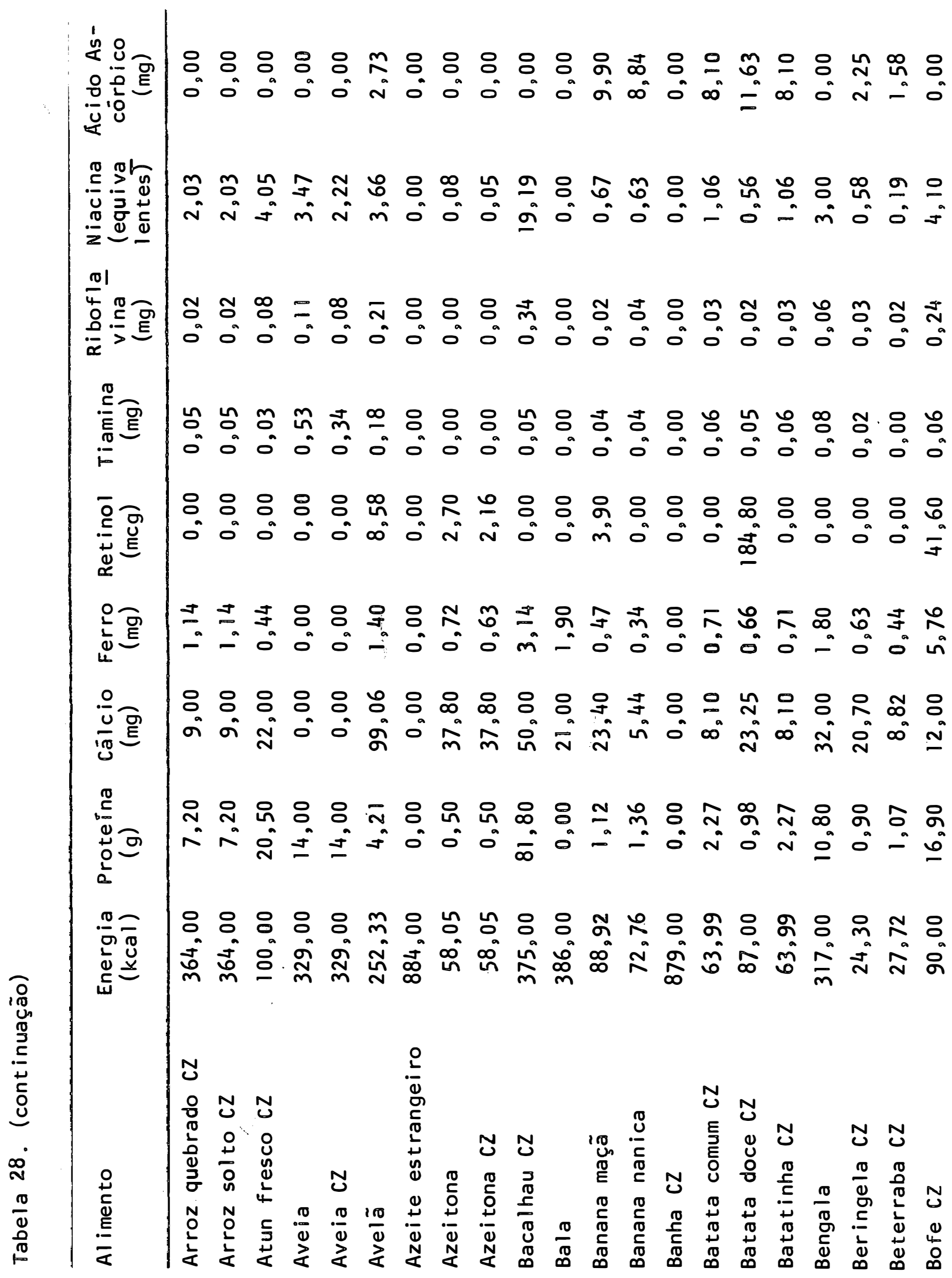




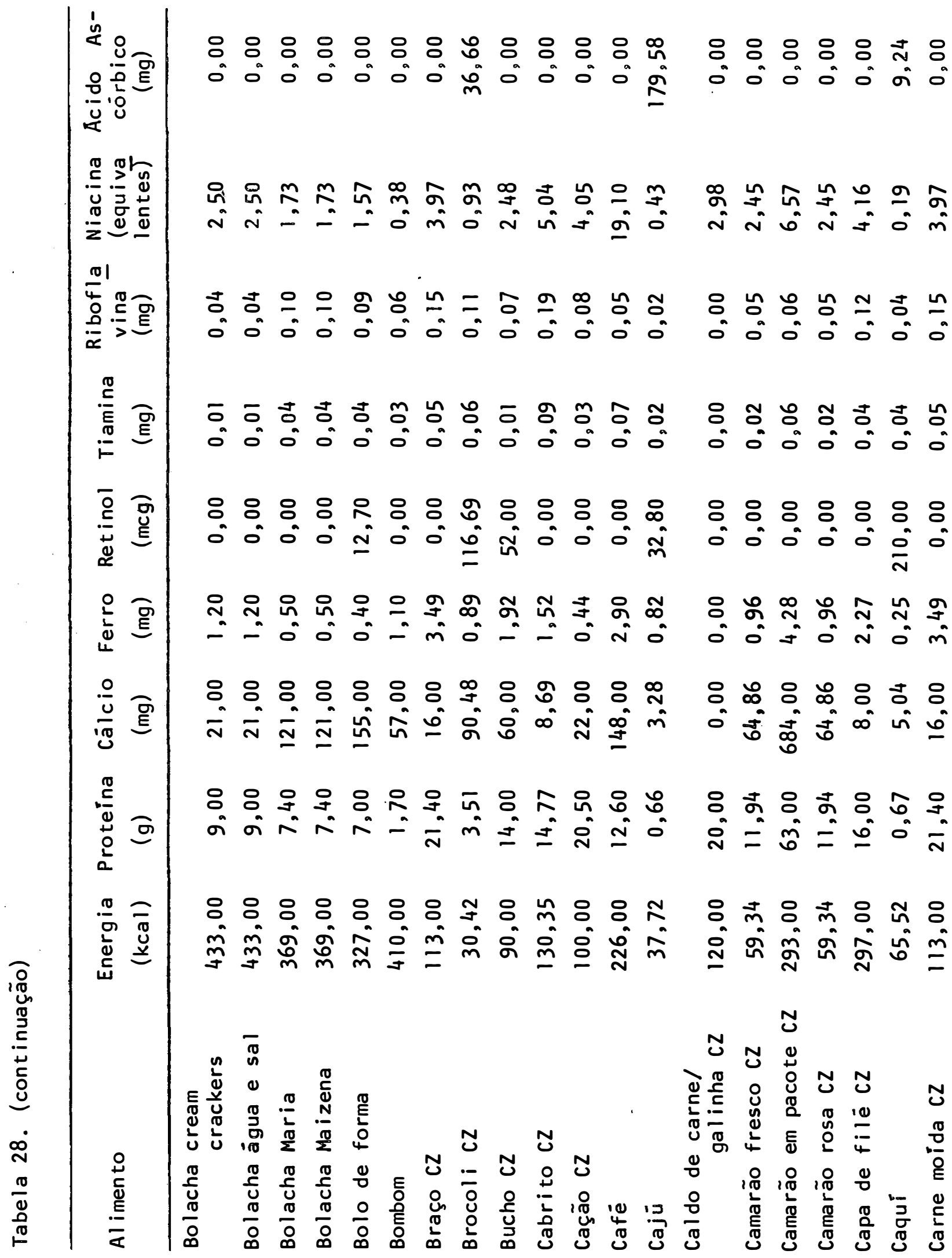




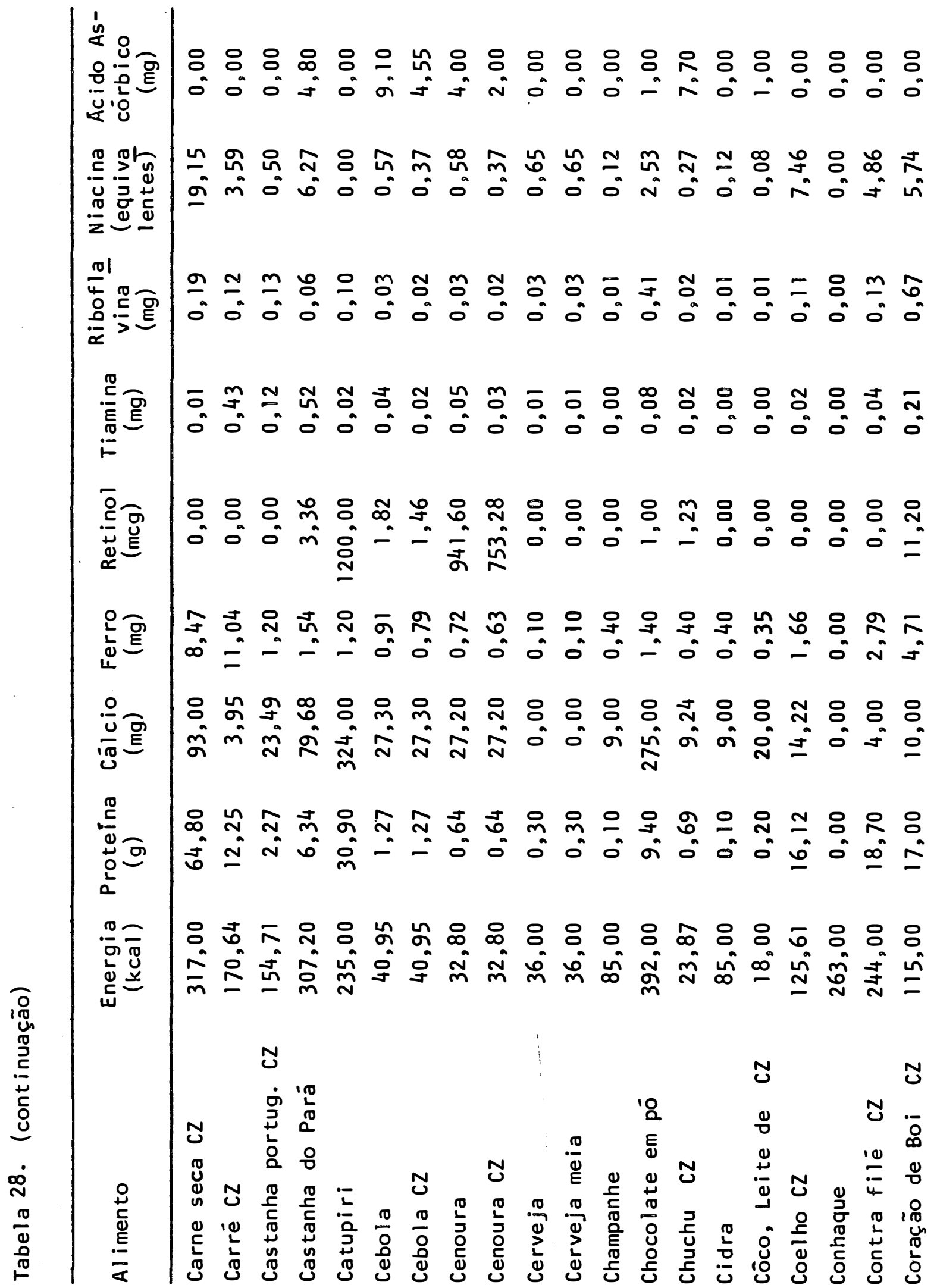




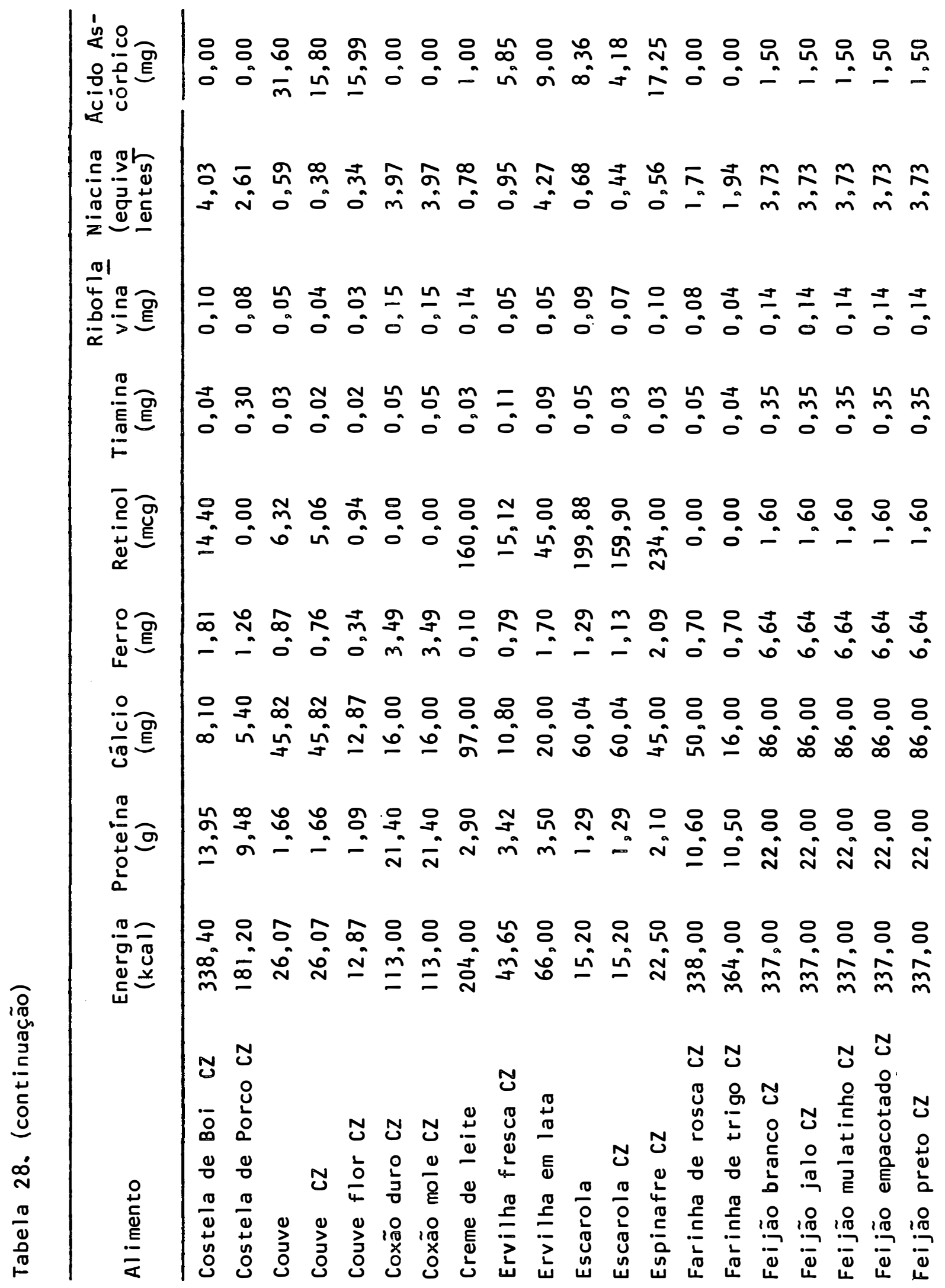




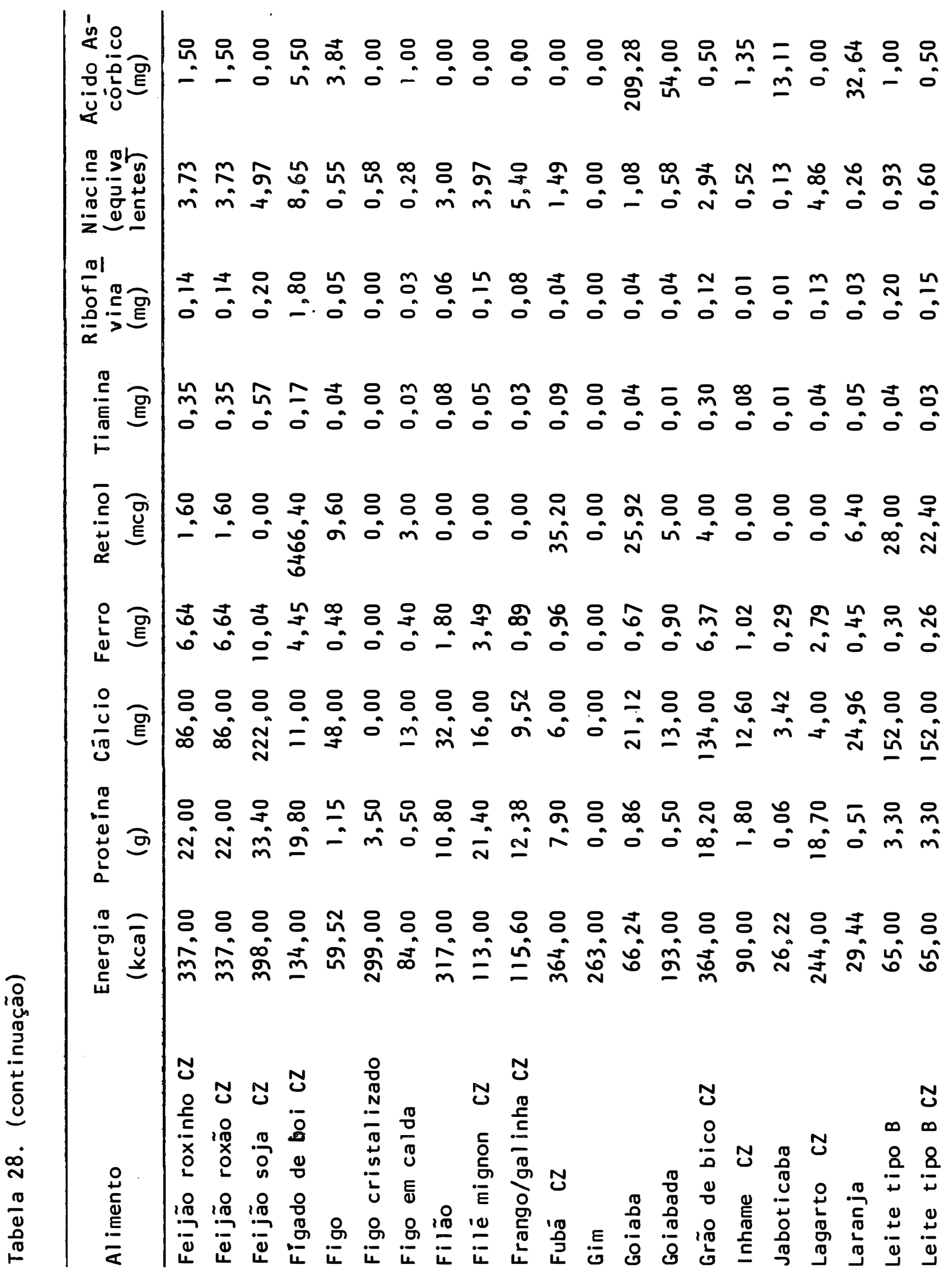




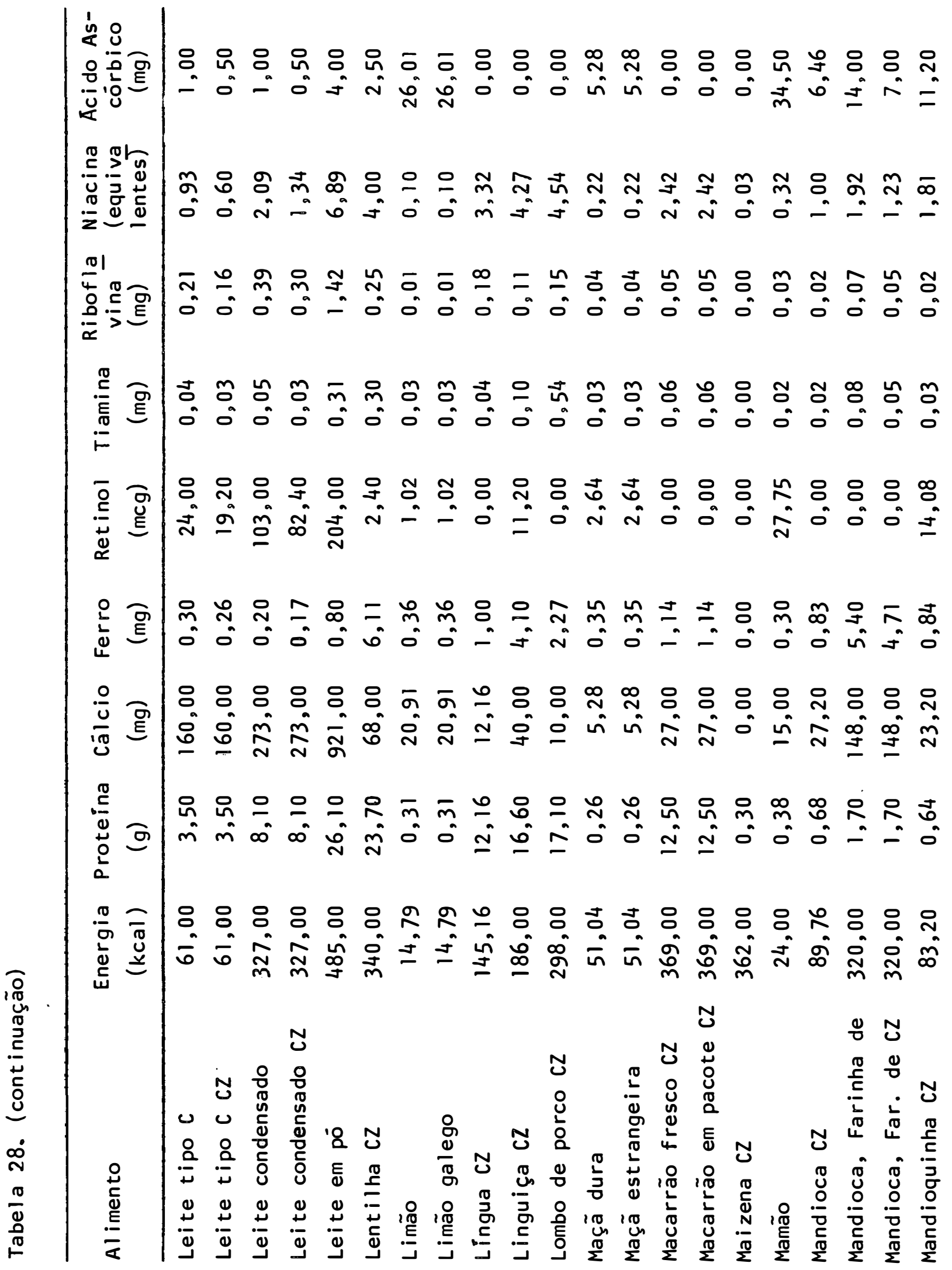




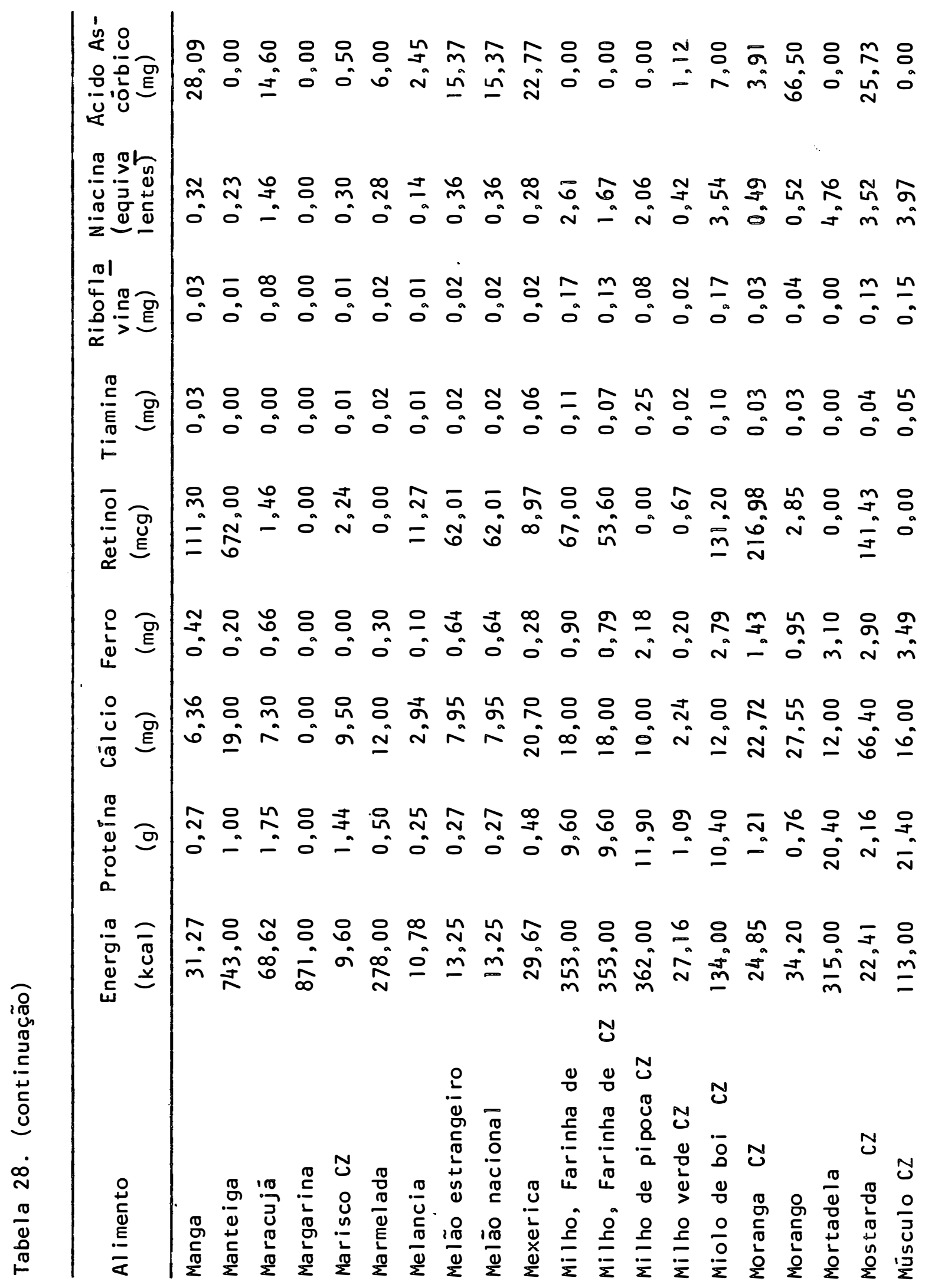




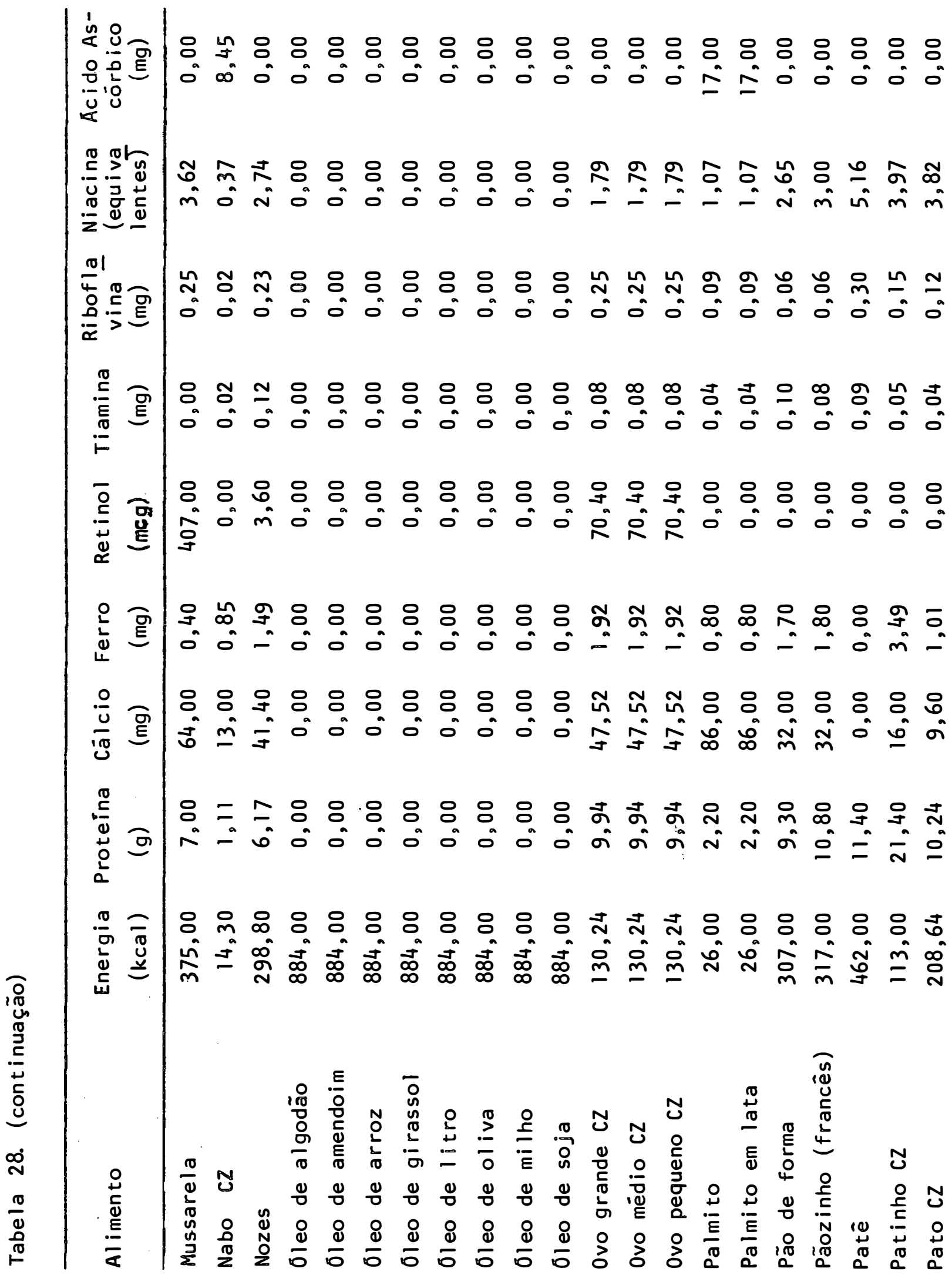


114.

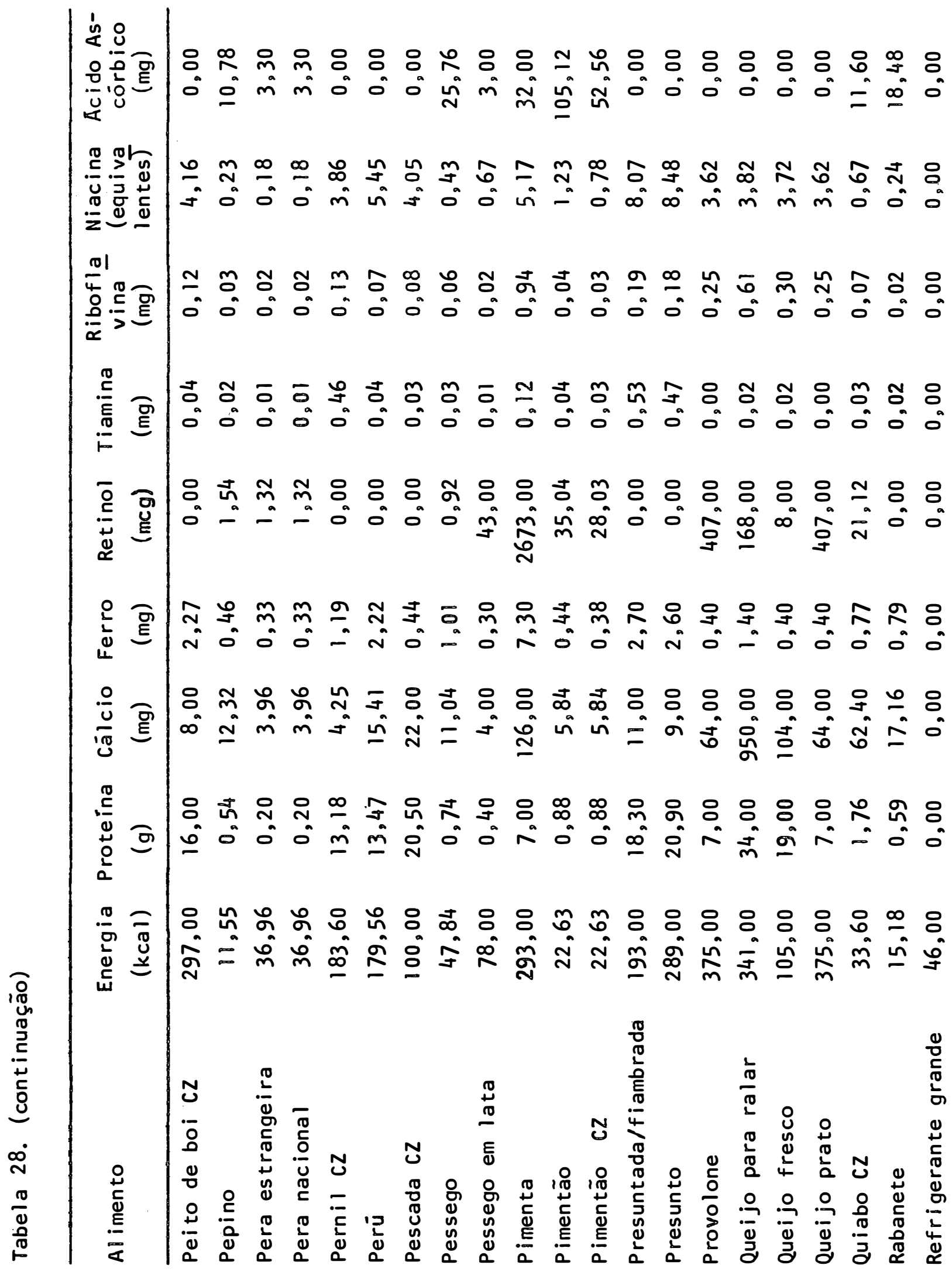


115.

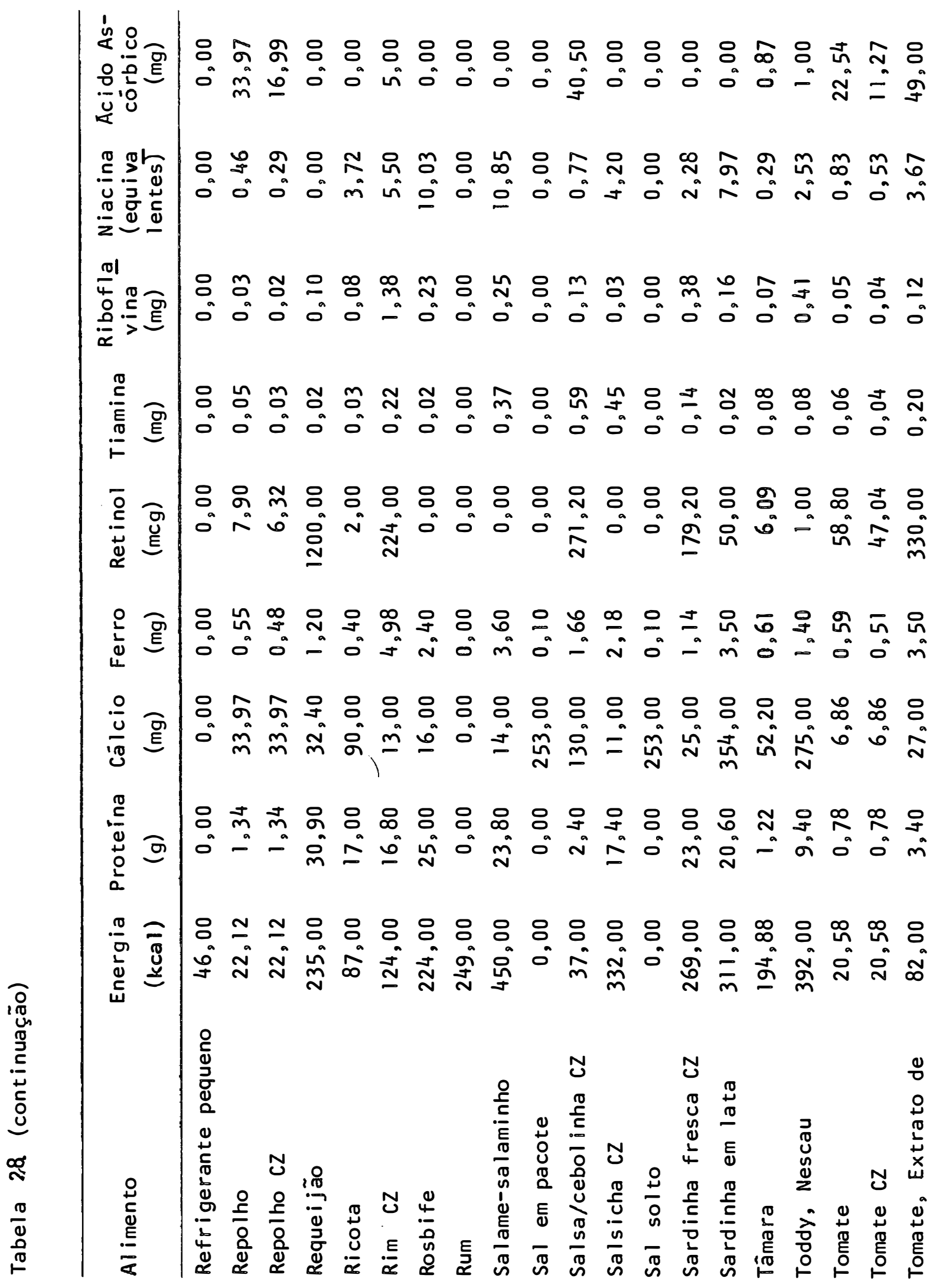




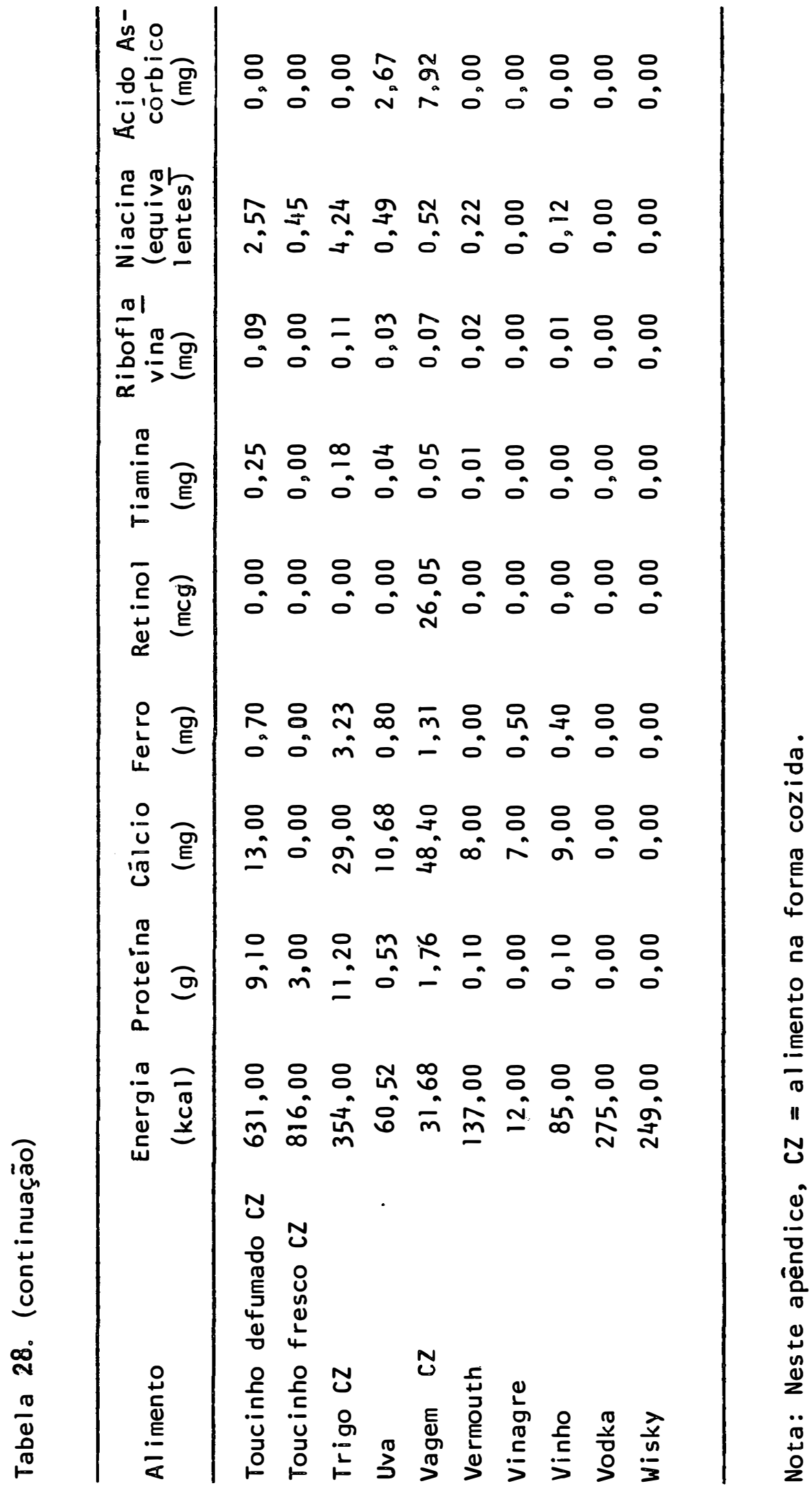




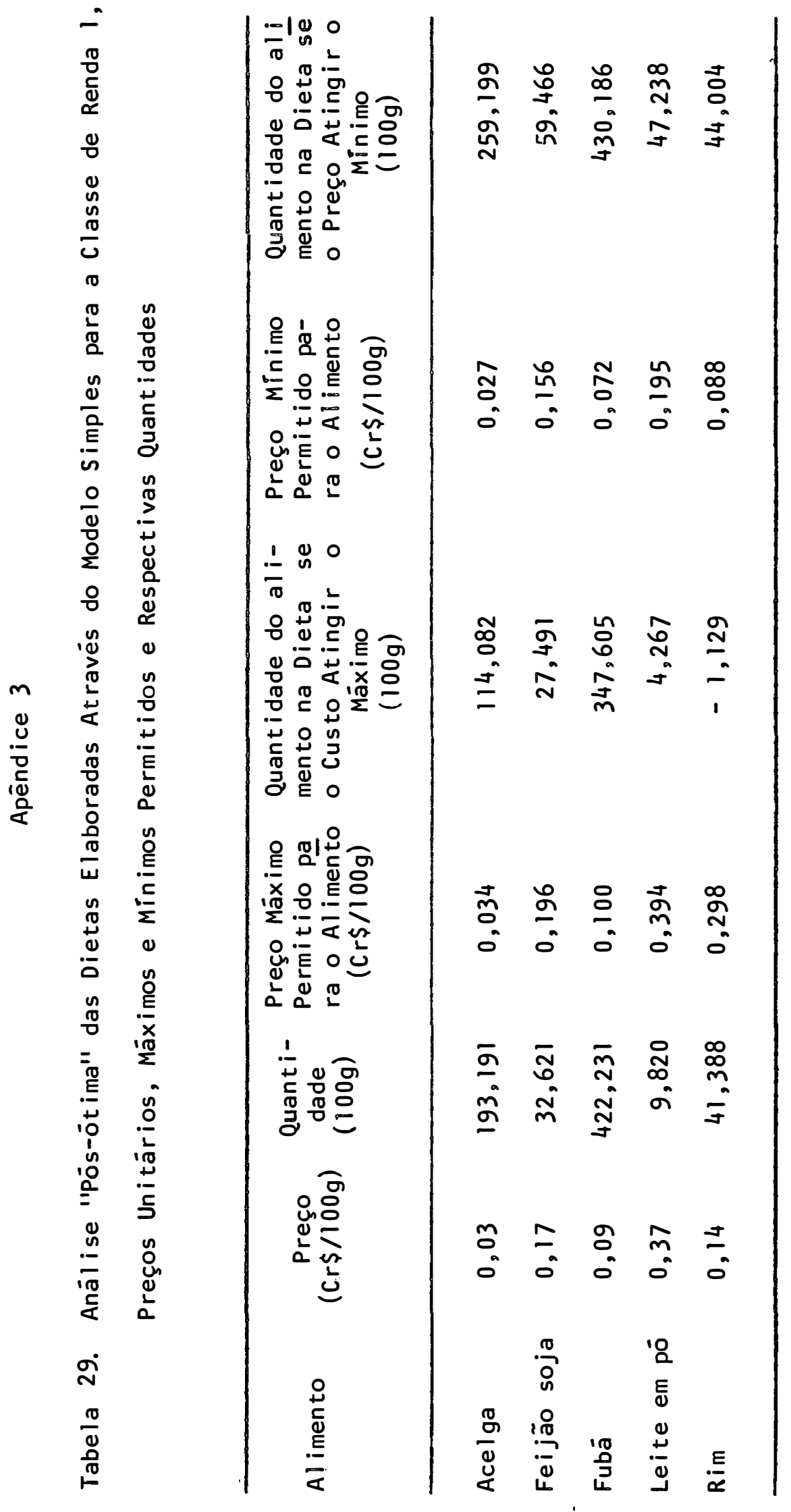




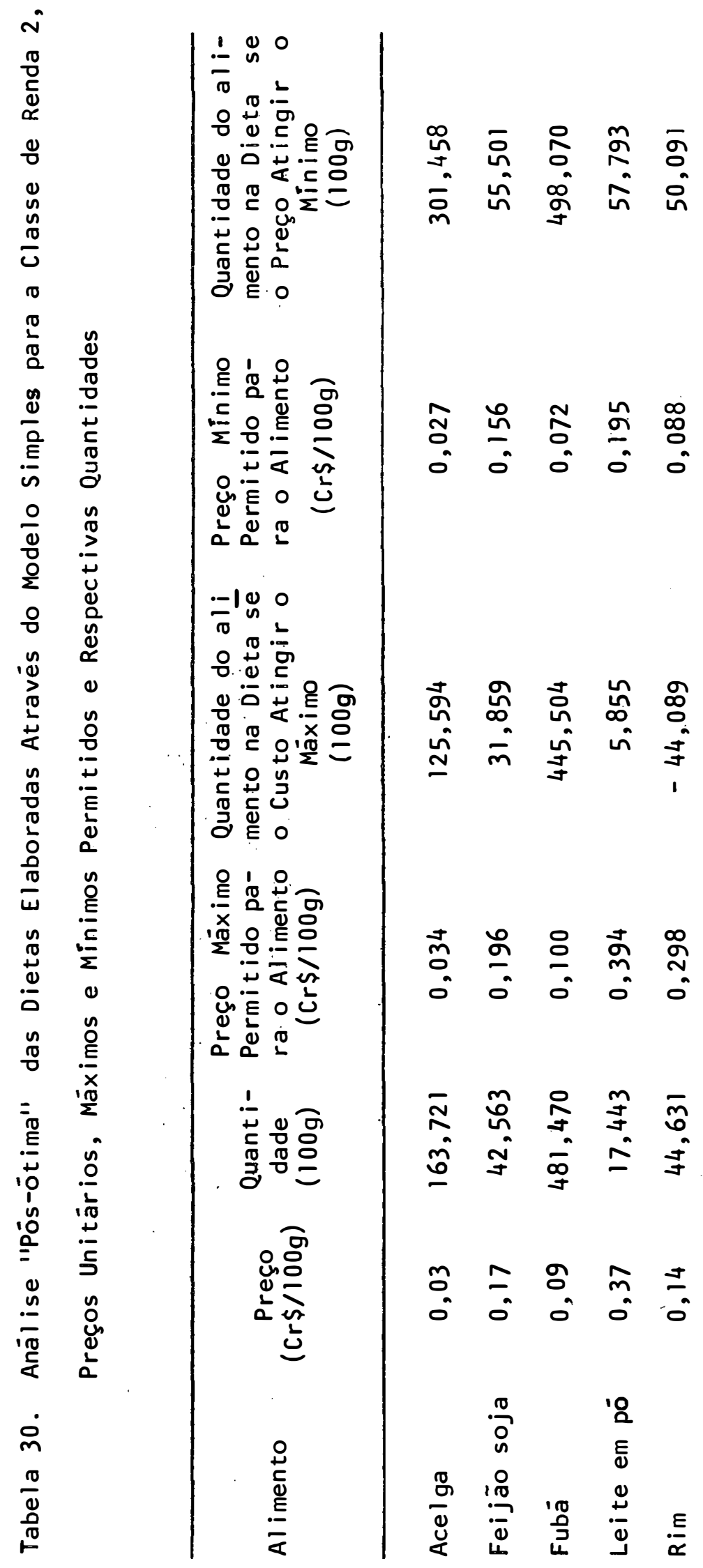


119.

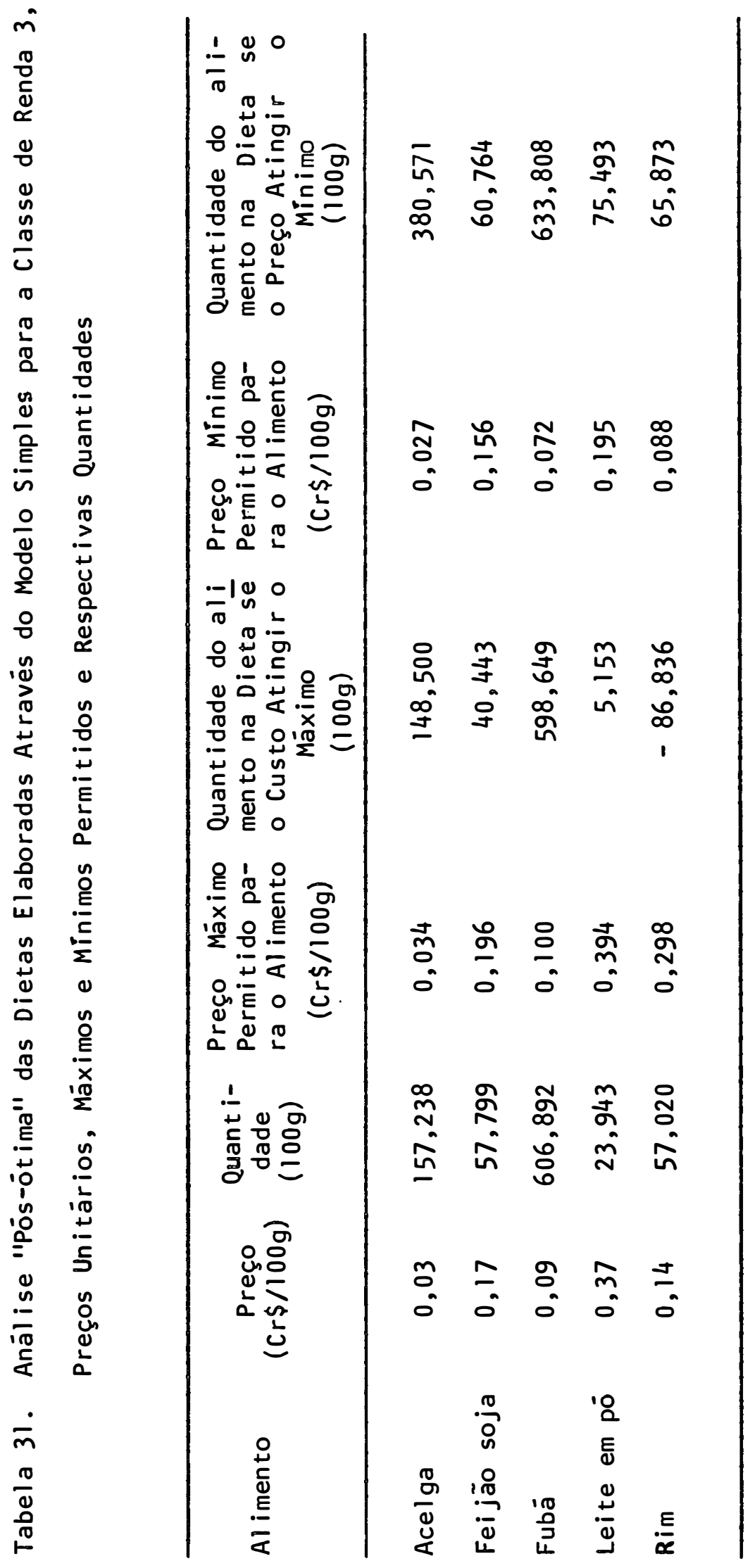


120.

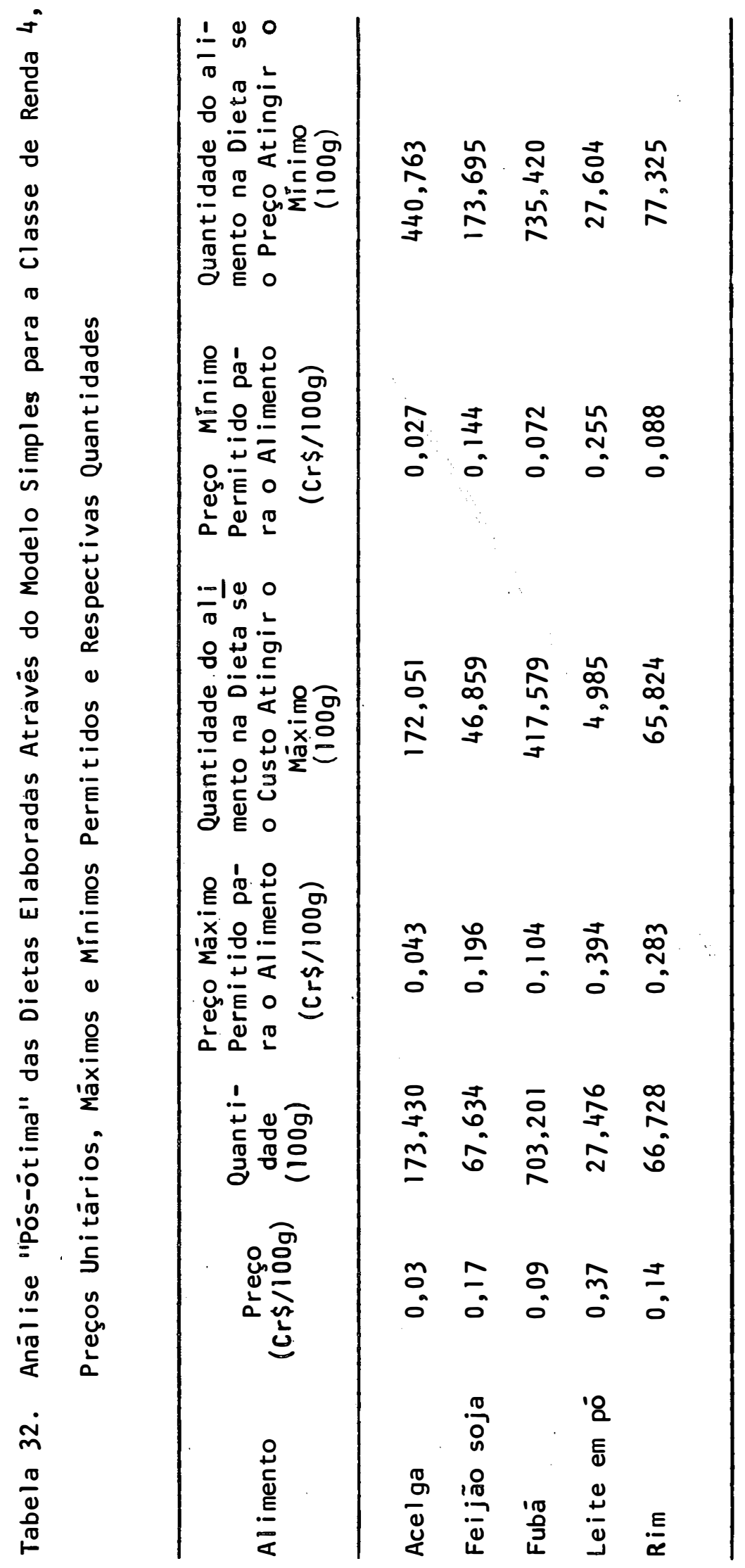


RI.

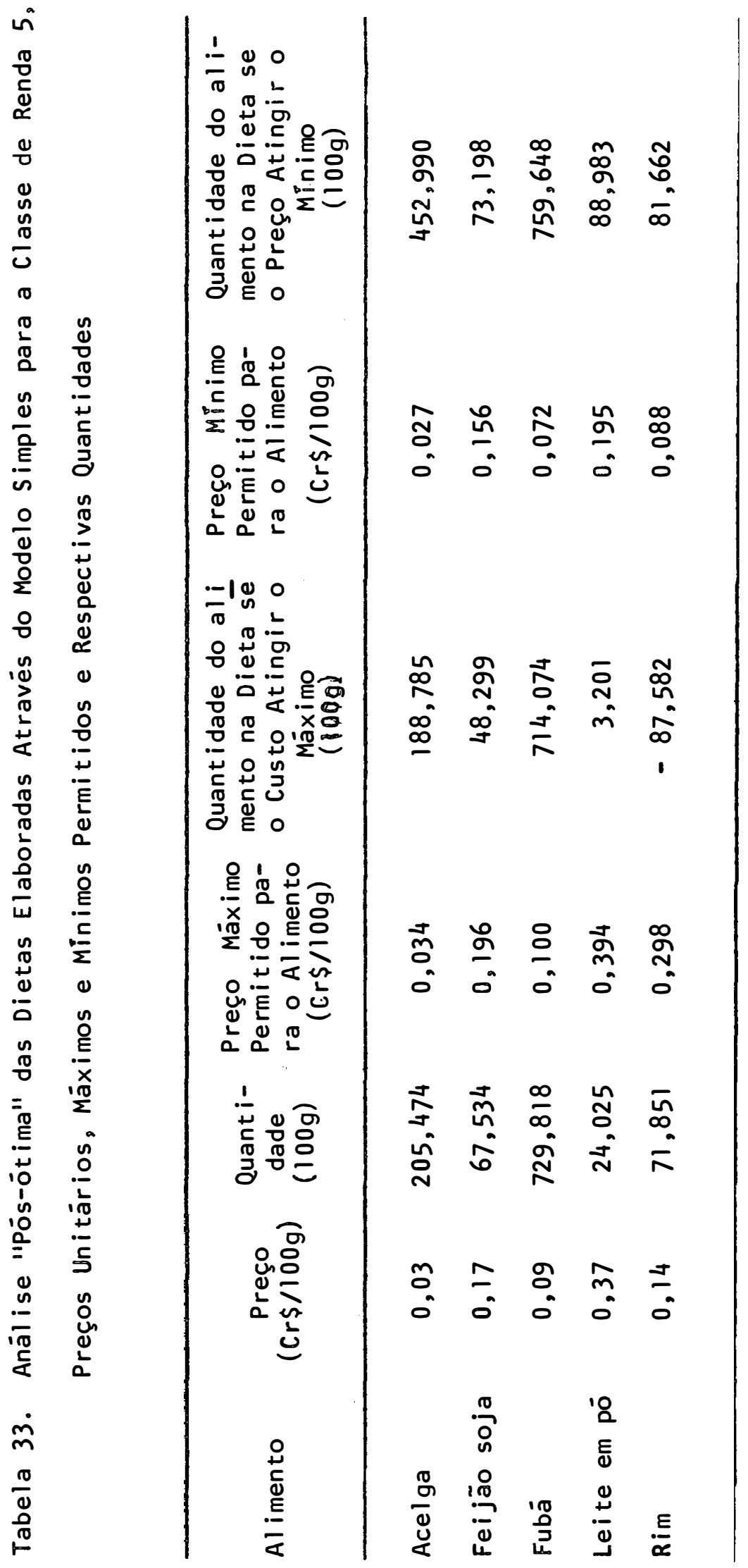




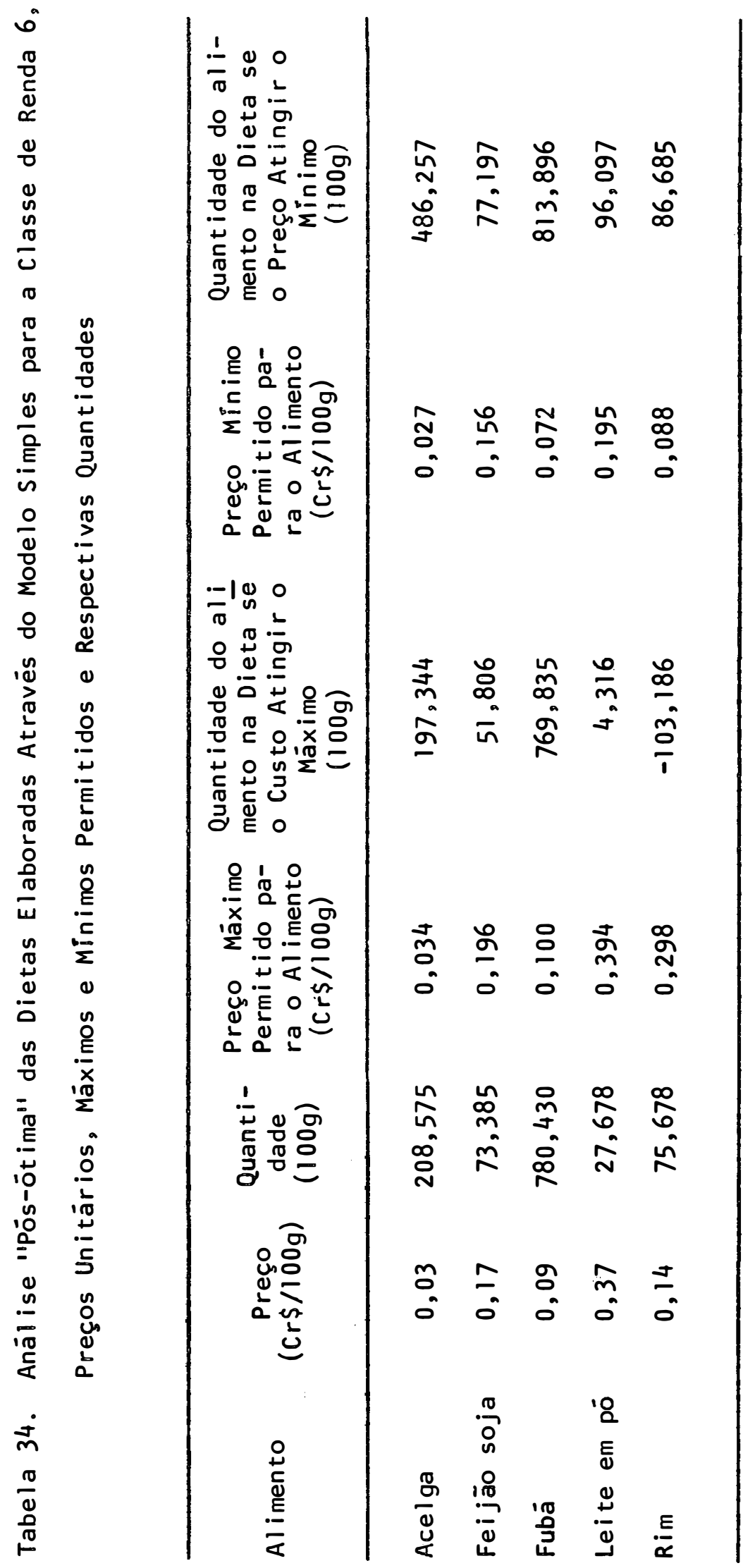


123.

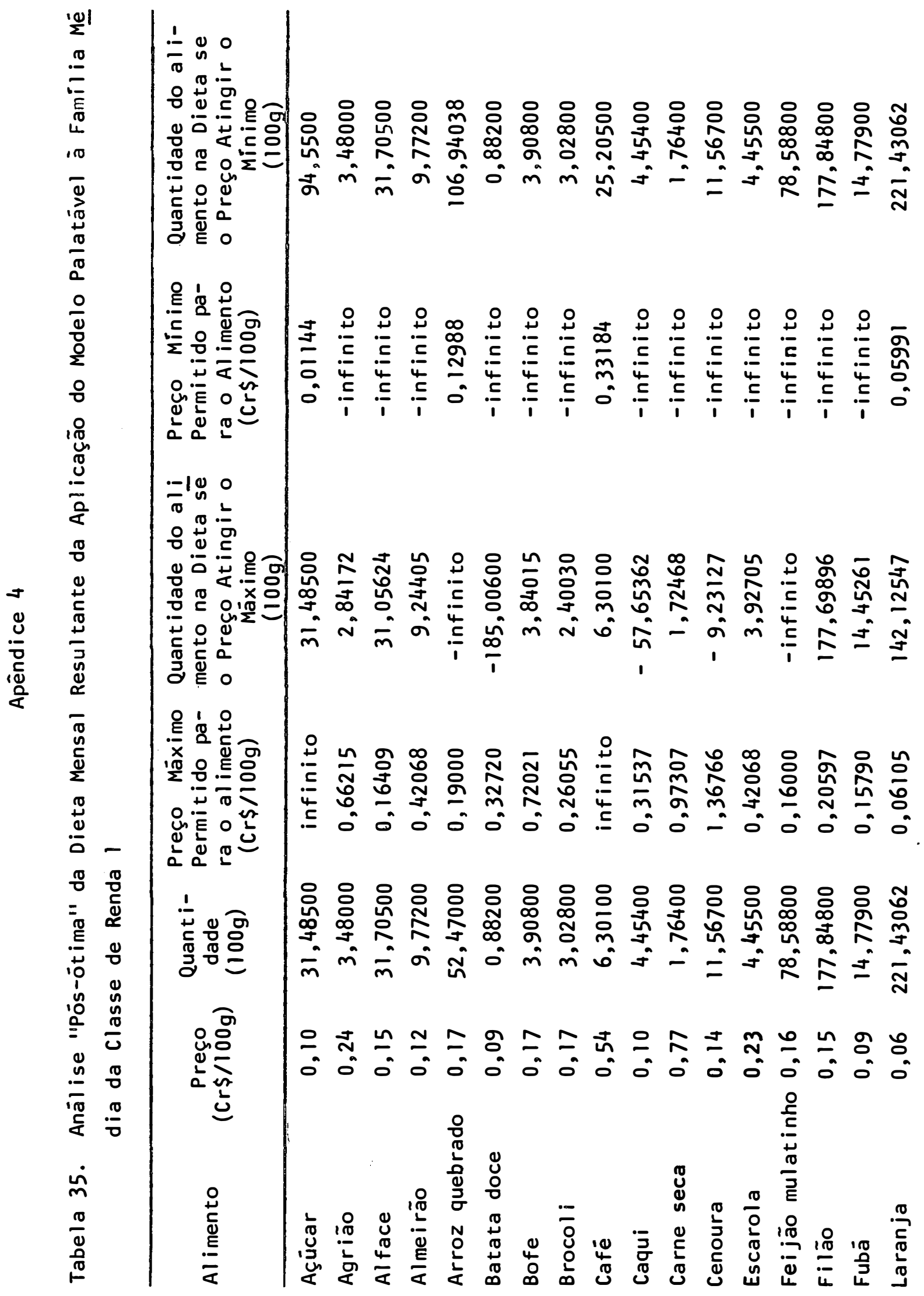




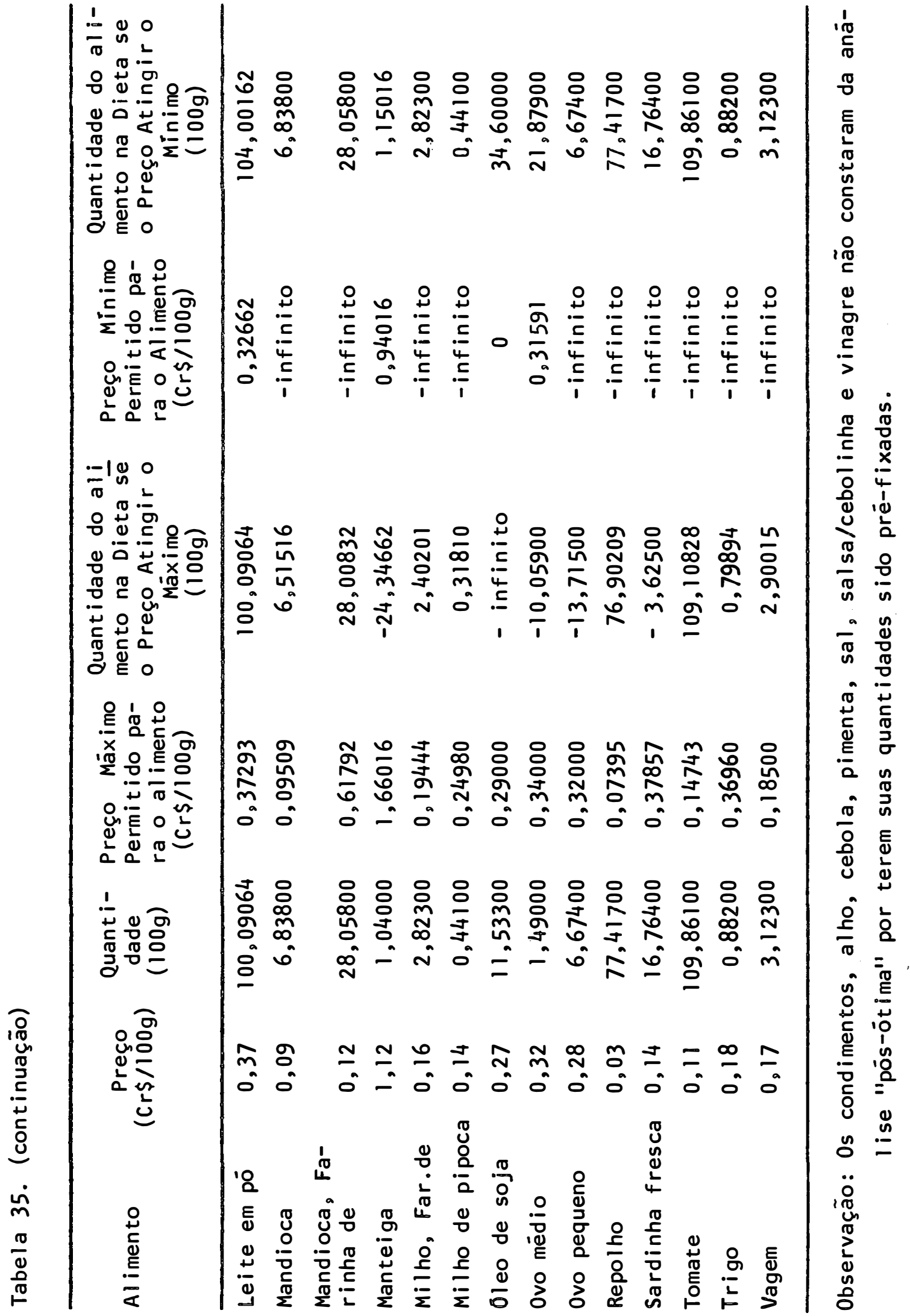


125.

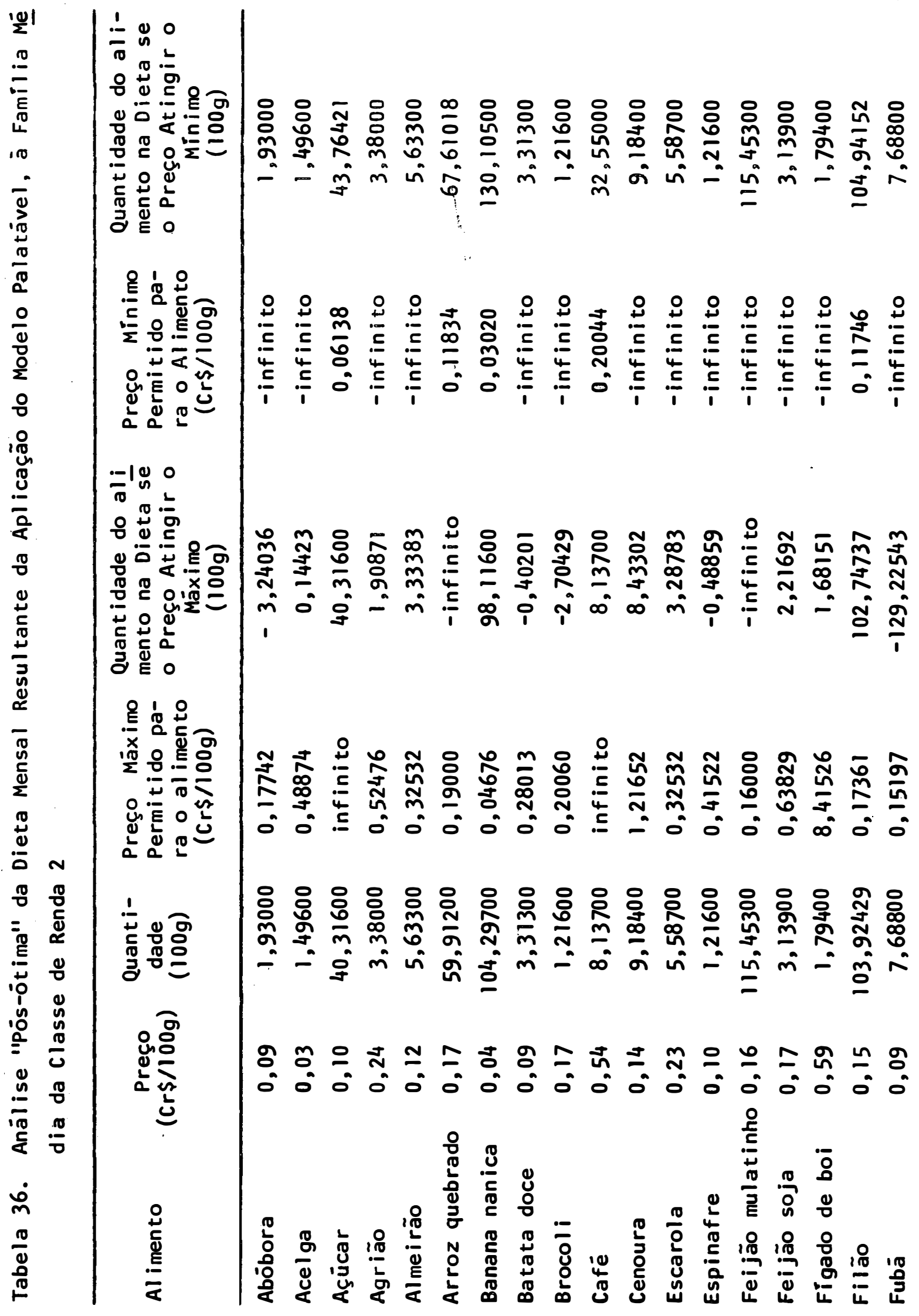




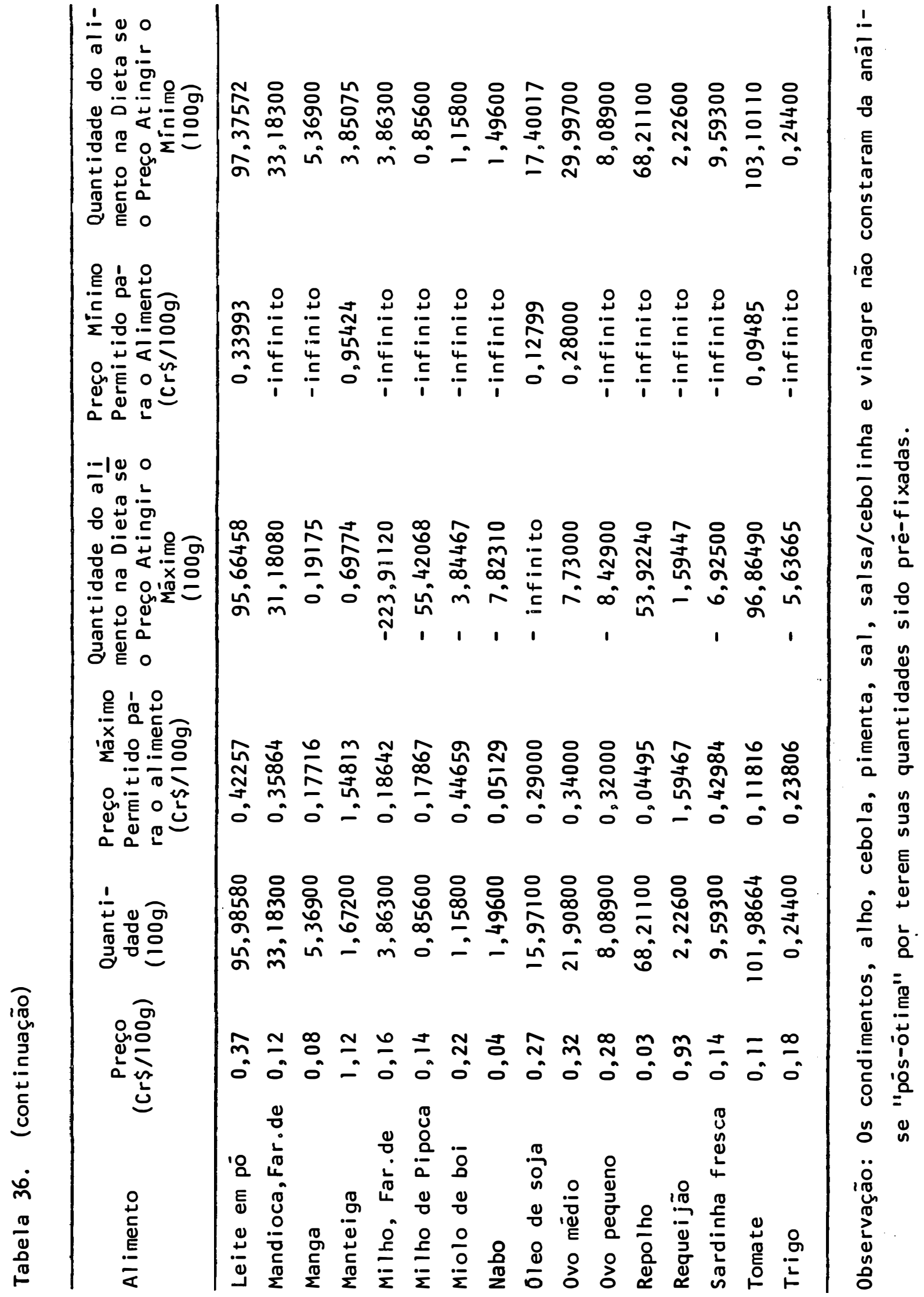




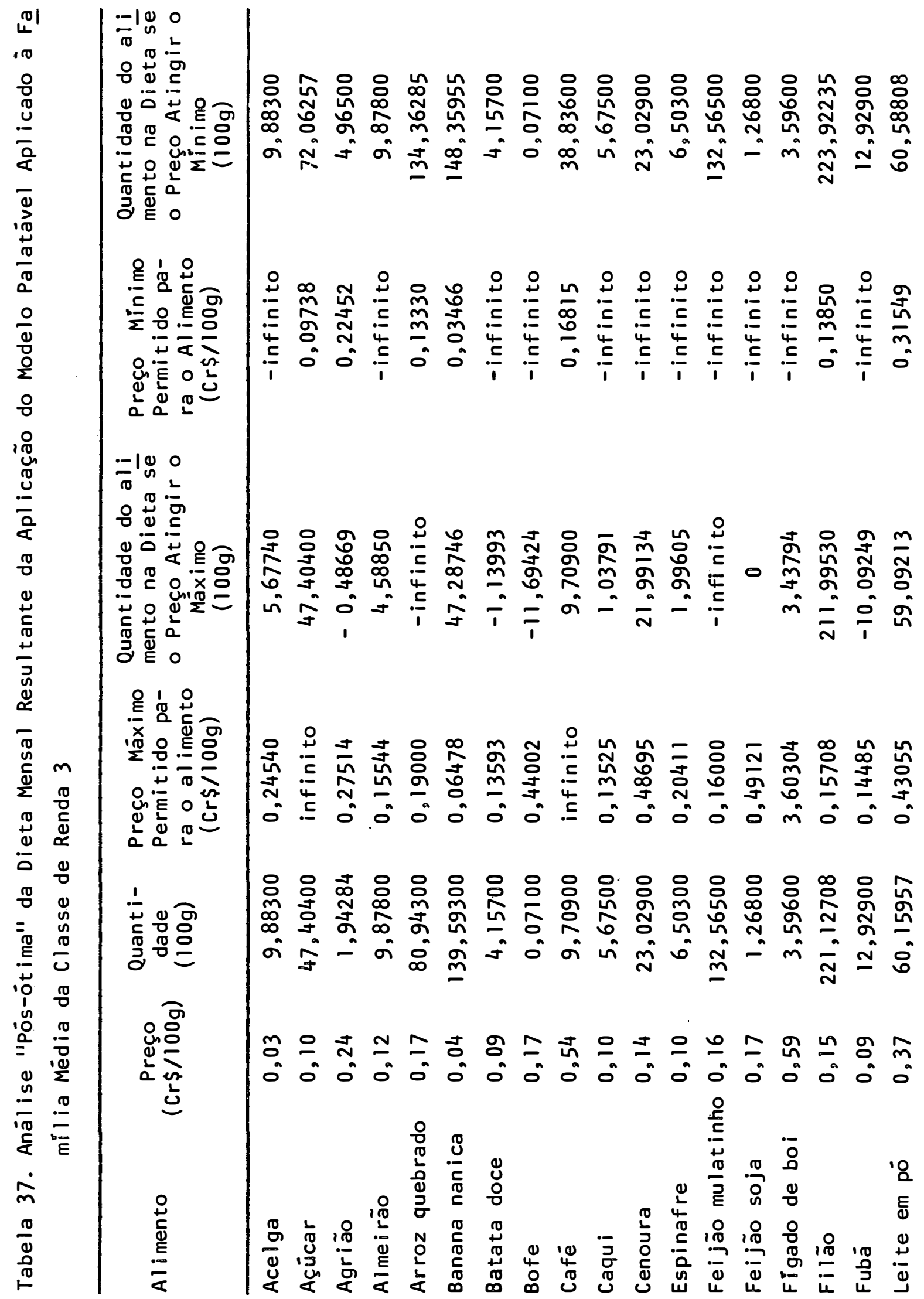




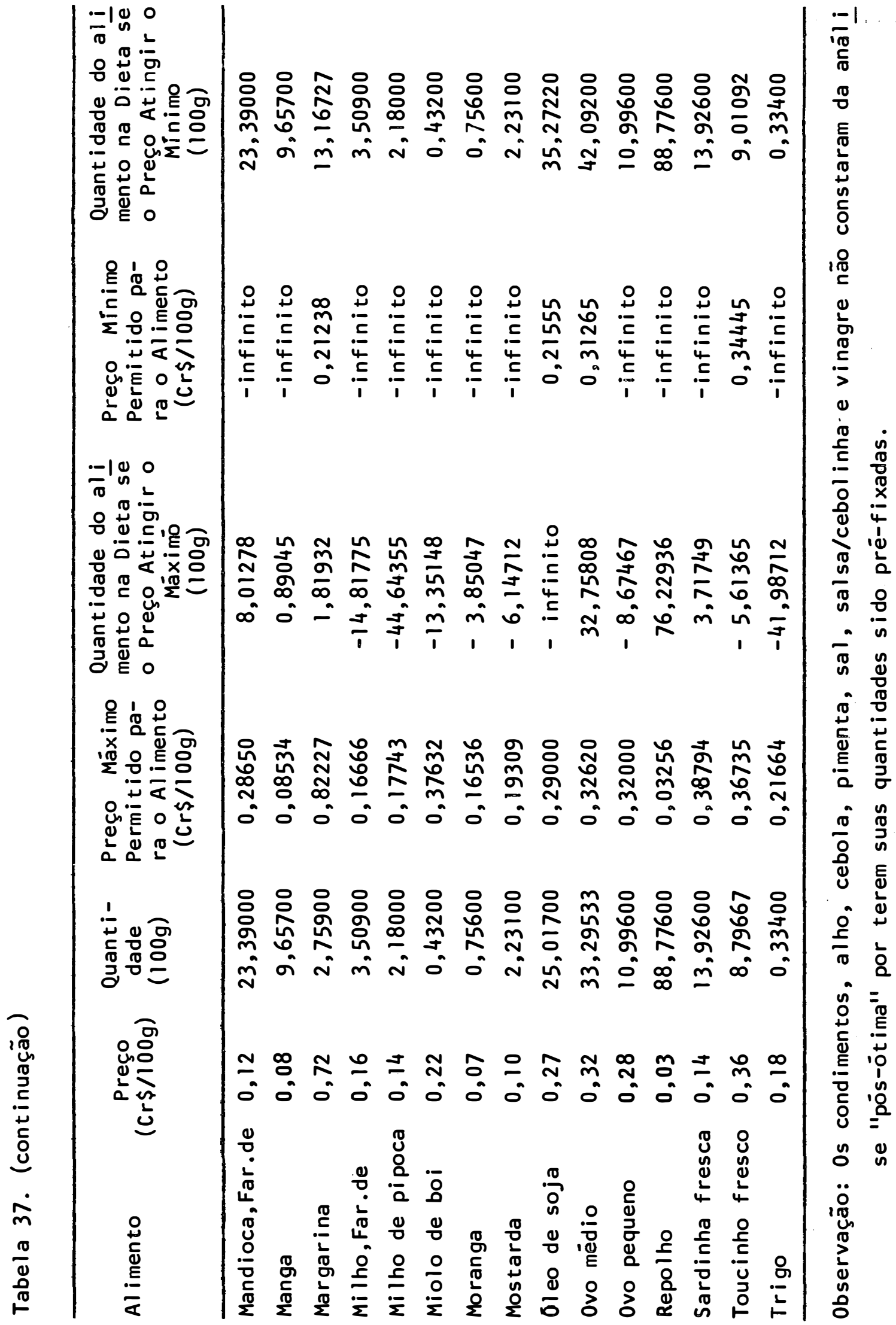




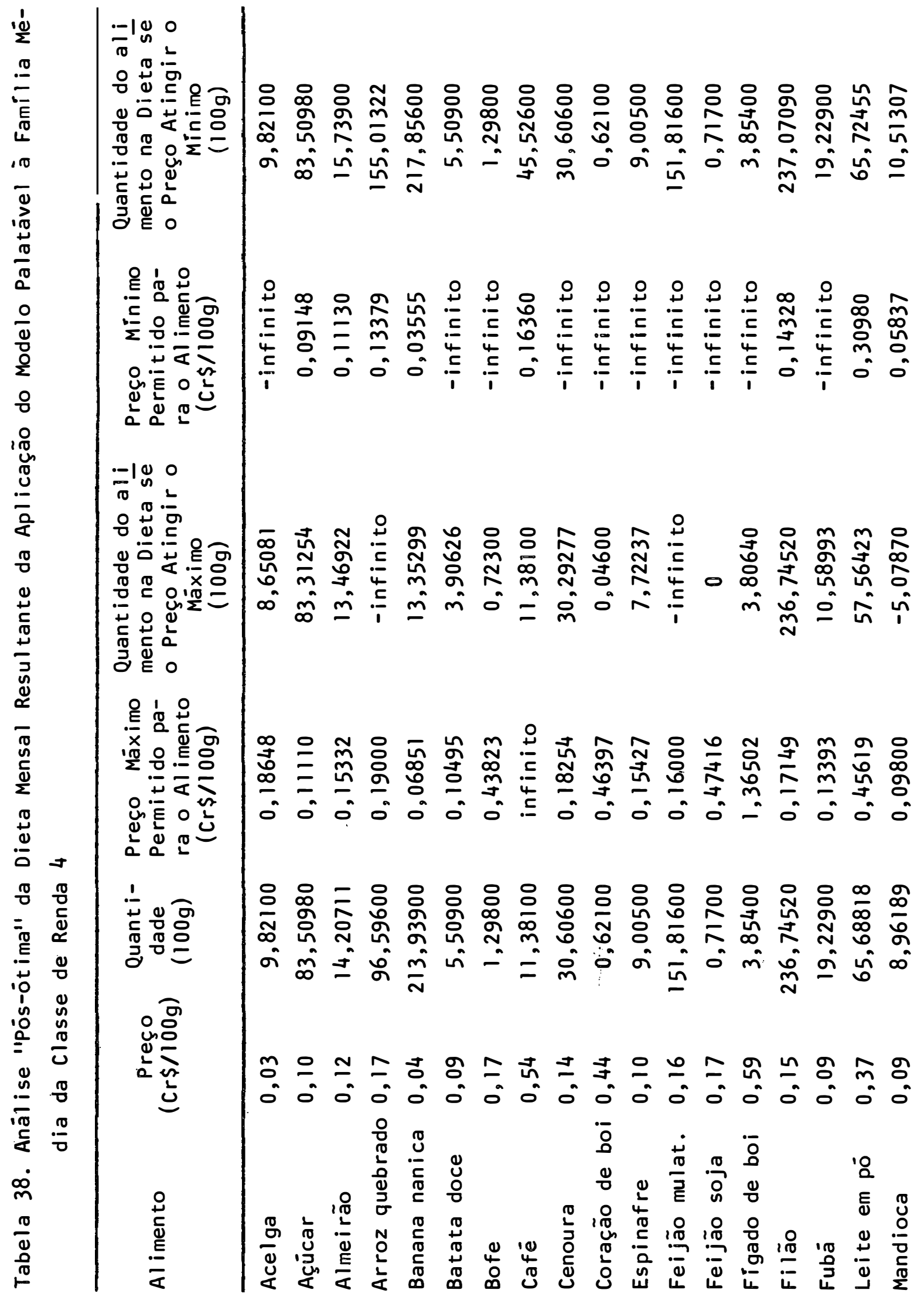




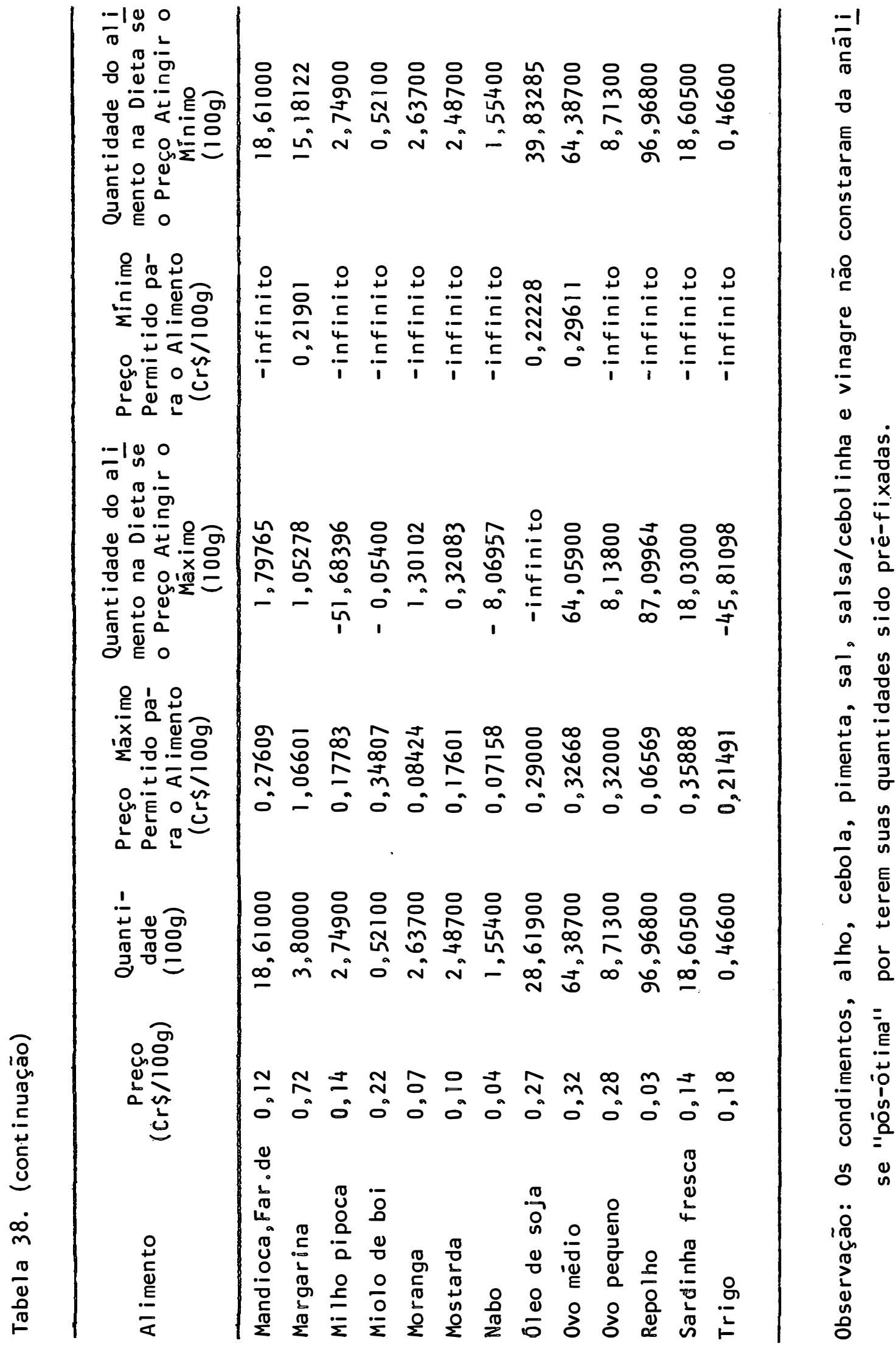


131.

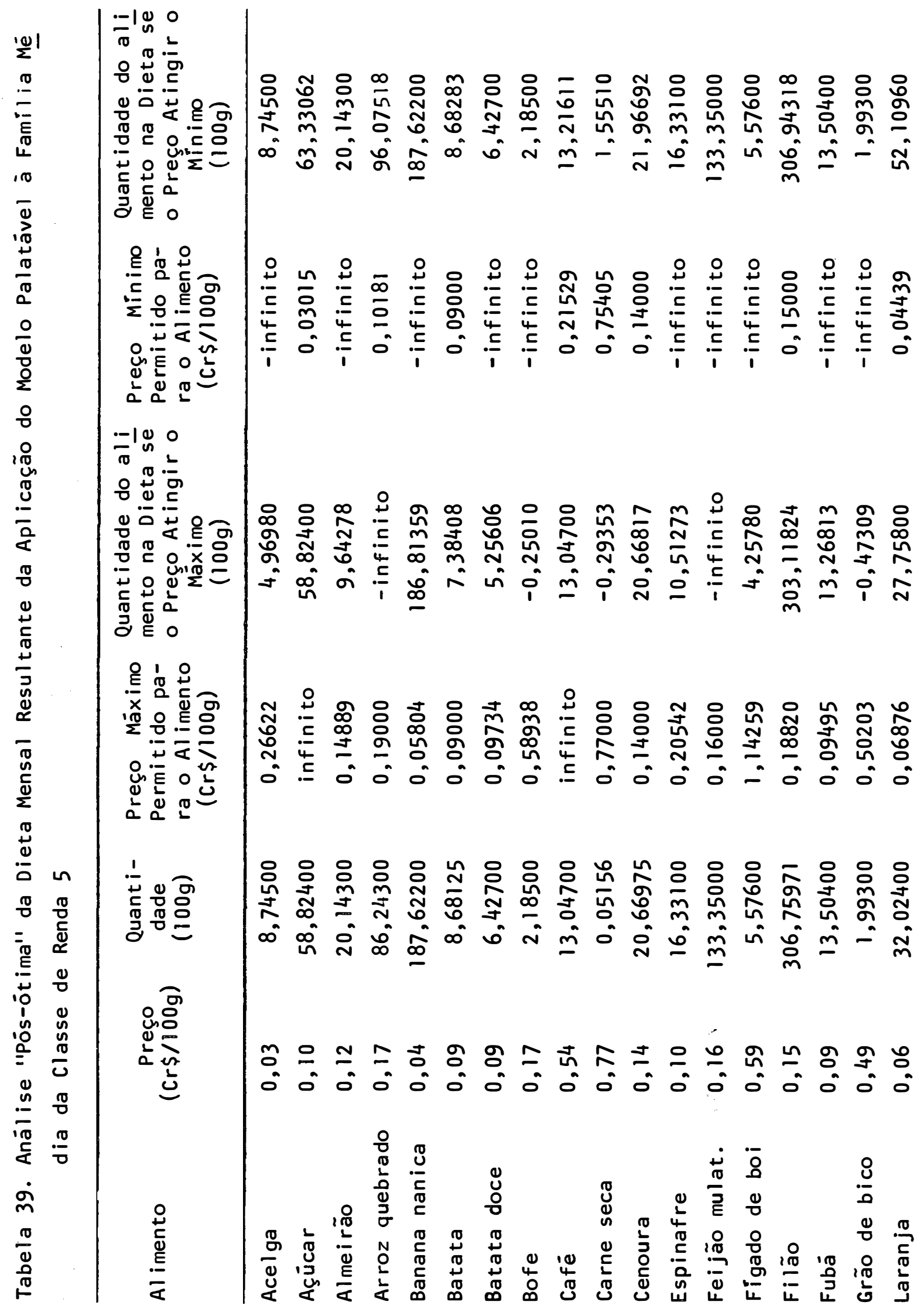




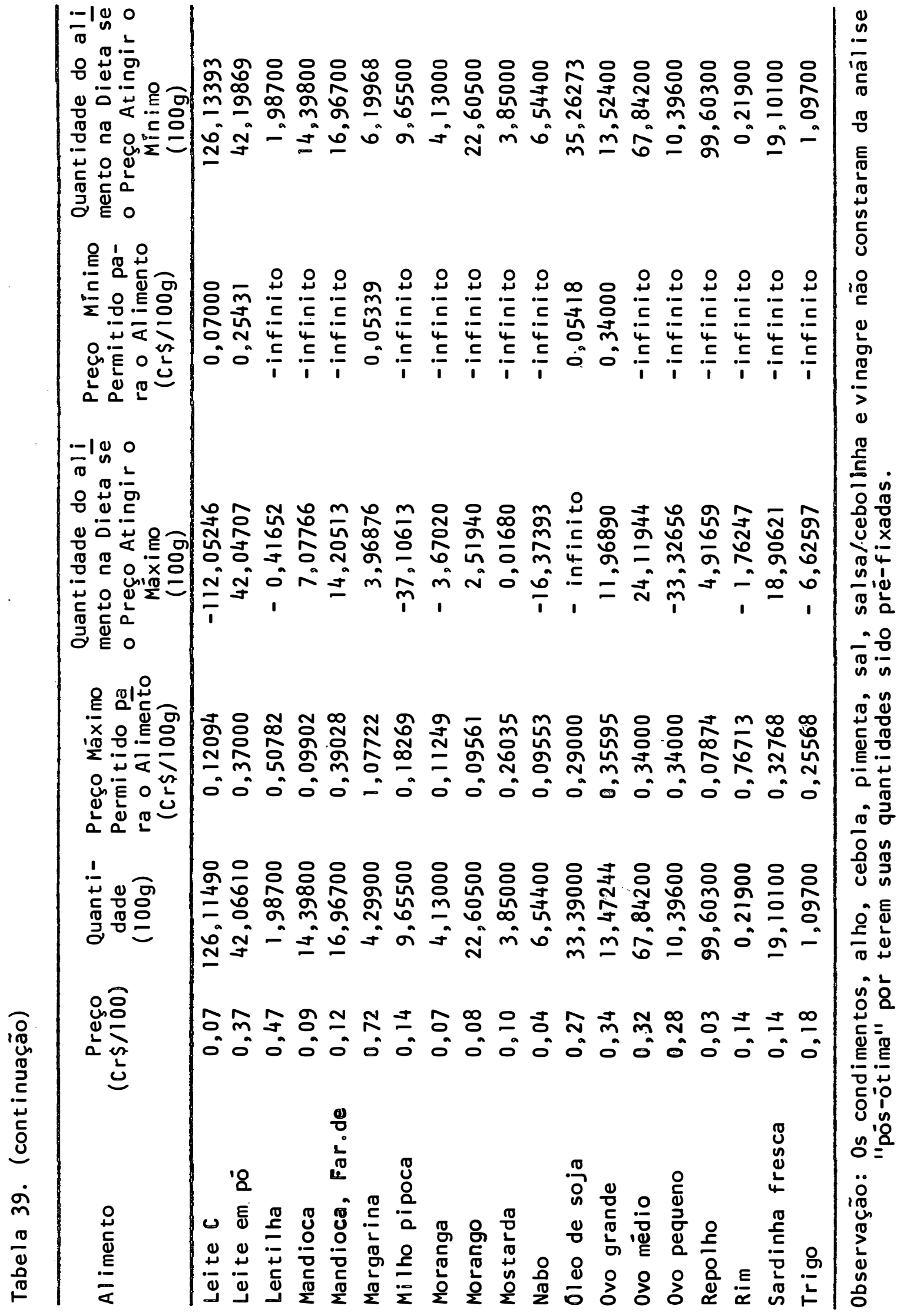




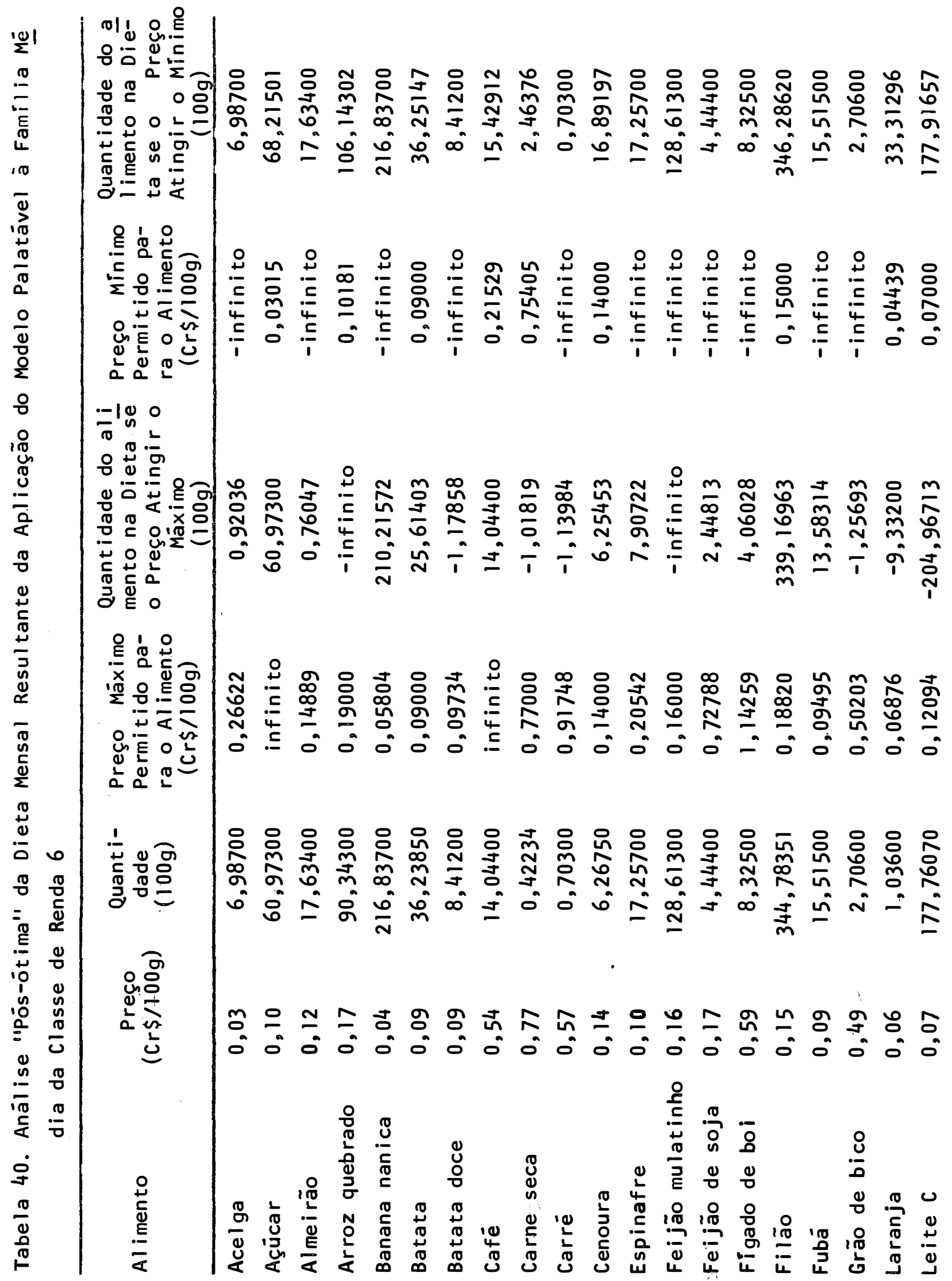




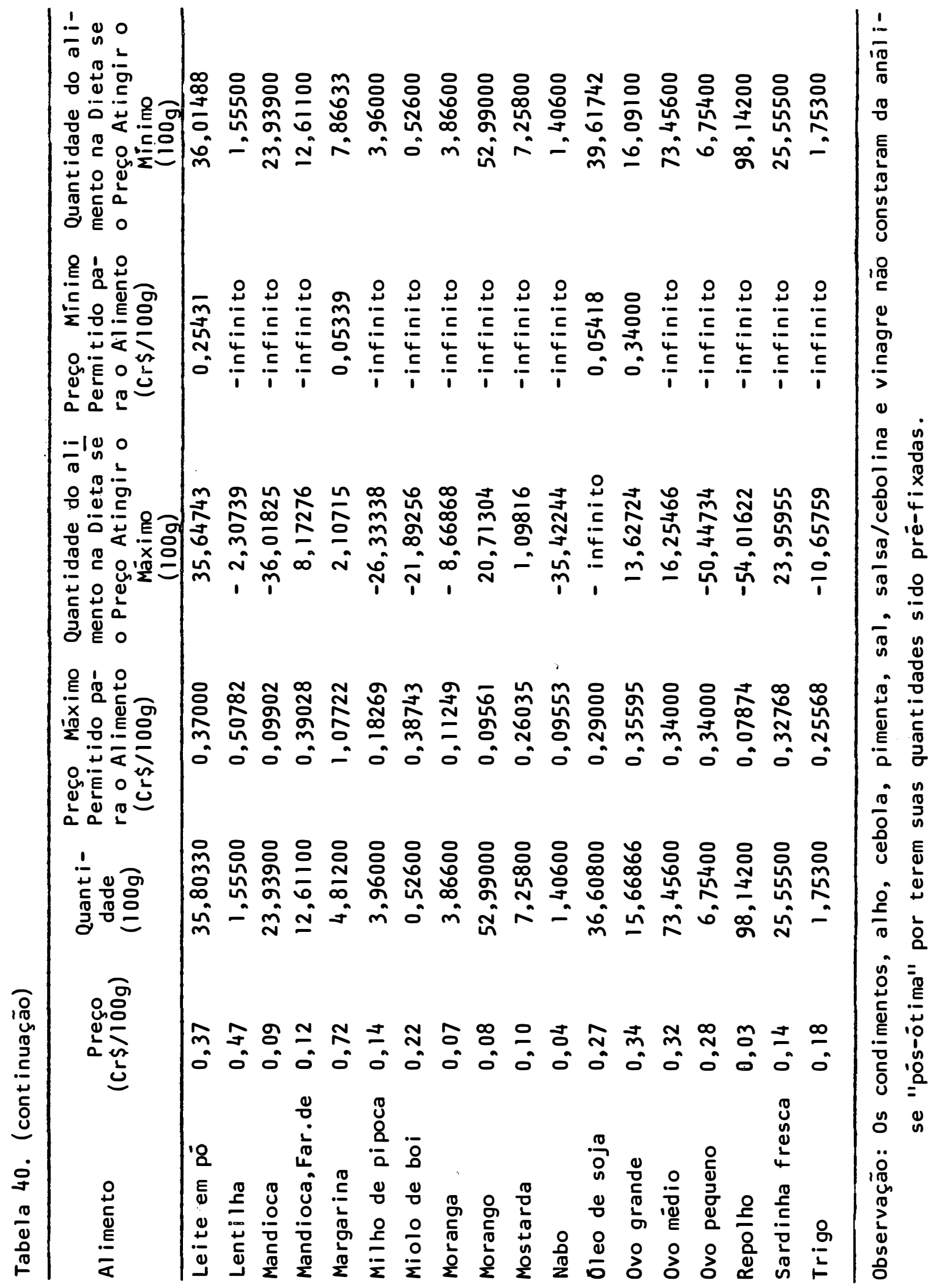

